PNL-7362

UC-600

\title{
Hanford Cultural Resources Laboratory Annual Report for Fiscal Year 1989
}

J. C. Chatters

N. A. Cadoret

P. E. Minthom

June 1990

Prepared for the U.S. Department of Energy under Contract DE-AC06-76RLO 1830

Pacific Northwest Laboratory

Operated for the U.S. Department of Energy

by Battelle Memorial Institute 


\title{
DISCLAIMER
}

This report was prepared as an account of work sponsored by an agency of the United States Government. Neither the United States Government nor any agency thereof, nor Battelle Memorial Institute, nor any of their employees, makes any warranty, expressed or implied, or assumes any legal Ilability or responsibility for the accuracy, completeness, or usefulness of any indomation, apparatus, product, or process disclosed, or represents that its use would not infringe privately owned rights. Reference herein to any specific commercial product, process, or service by trade name, tradernark, manufacturer, or otherwise, does not necessarily constitute or imply its endorsement, recommendation, or favoring by the United States Governmem or any agency thereof, or Battelle Memorial Institute. The views and opinions of authors expressed herein do not necessarily state or reflect those of the United States Government or any agency thereof.

\author{
PACIFIC NORTHWEST LABORATORY \\ operated by \\ BATTELLE MEMORIAL. INSTITUTE \\ for the \\ UNITED STATES DEPARTMENT OF ENERGY \\ under Contract DE-ACO6-76RLO 1830
}

Printed in the United States of America

Available to DOE and DOE contractors from the

Office of Scientific and Technical Information, P.O. Box 62, Oak Ridge, TN 37831; prices available from (615) 576-8401. FTS 626-8401.

Available to the public from the National Technical Information Service,

U.S. Department of Commerce, 5285 Port Royal Rd., Springfield, VA 22161.

NTIS Price Codes, Microliche A01

Printed Copy

\begin{tabular}{cr}
\hline Price Code & Page Range \\
\hline A02 & $1-10$ \\
A03 & $11-50$ \\
AO4 & $51-75$ \\
A05 & $76-100$ \\
A06 & $101-125$ \\
A07 & $126-150$ \\
A08 & $151-175$ \\
A09 & $176-200$ \\
A10 & $201-225$ \\
A11 & $226-250$ \\
A12 & $251-275$ \\
A13 & $276-300$ \\
A14 & $301-325$
\end{tabular}

\begin{tabular}{cc}
\hline Price Code & Page Ranise \\
\hline A15 & $326-350$ \\
A16 & $351-375$ \\
A17 & $376-400$ \\
A18 & $401-425$ \\
A19 & $426-450$ \\
A20 & $451-475$ \\
A21 & $476-500$ \\
A22 & $501-525$ \\
A23 & $526-550$ \\
A24 & $551-575$ \\
A25 & $576-600$ \\
A99 & $601-U p$
\end{tabular}




\title{
HANFORD CULTURAL RESOURCES LABORATORY ANNUAL REPORT FOR FISCAL YEAR 1989
}

\author{
J. C. Chatters \\ N. A. Cadoret \\ P. E. Minthom
}

June 1990

Prepared for

the U.S. Department of Energy

under Contract DE-AC06-76RLO 1830

Pacific Northwest Laboratory

Richland, Washington 99352 


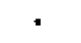

.

$\therefore$

.

: 


\begin{abstract}
This report summarizes activities of the Hanford Cultural Resources Laboratory (HCRL) during fiscal year 1989. The HCRL provides support for managing the archaeological, historical, and cultural resources of the Hanford Site, Washington, in a manner consistent with the National Historic Preservation Act of 1966, the Archaeological Resources Protection Act of 1979, and the American Indian Religious Freedom Act of 1978. A major task in FY 1989 was completion and publication of the Hanford Cultural Resources Management Plan, which prioritizes tasks to be undertaken to bring the U.S. Department of Energy - Ricluland Operations into compliance with federal statutes, relations, and guidelines. During FY 1989, six tasks were performed. In order of priority, these were 1) conducting 107 cultural resource reviews, 2) monitoring the condition of 40 known prehistoric archaeological sites, 3 ) assessing the condition of artifact collections from the Hanford Site, 4) evaluating three sites and nominating two of those to the National Register of Historic Places, 5) developing an education program and presenting 11 lectures to public organizations, and 6) surveying approximately $1 \mathrm{mi}^{2}$ of the Hanford Site for cultural resources.
\end{abstract}




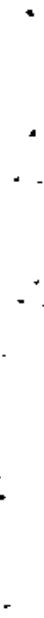




\section{EXECUTIVE SUMMARY}

The Hanford Cultural Resources Laboratory (HCRL) was established by the U.S. Department of Energy-Richland Operations (DOE-RL) in 1987 as part of the Pacific Northwest Laboratory (PNL). The HCRL provides support for managing the archaeological, historical, and cultural resources of the Hanford Site, Washington, in a manner consistent with the National Historic Preservation Act (NHPA) of 1966, the Archaeological Resources Protection Act of 1979, and the American Indian Religious Freedom Act of 1978. This report summarizes activities of the HCRL during fiscal year (FY) 1989.

HCRL responsibilities have been set forth in the Hanford Cultural Resources Management Plan as a prioritized list of tasks to be undertaken to bring the DOE-RL into compliance with federal statues, regulations, and guidelines. Although the plan was not finalized until 1989, the task list was used to guide culnural resources management activities during FY 1989 and is the ourline for this report.

A major task in FY 1989, although not on the prioritized list, was completion and publication of the Hanford Cultural Resources Management Plan (HCRMP). Multiple drafts of the plan were reviewed by DOE-RL, the Washington State Historic Preservation Officer, the Advisory Council for Historic Preservation, the Wanapum band, Yakima, Umatilla, Nez Perce, and Colville Tribes, the National Park Service, and the U.S. Army Corps of Engineers. Following extensive revisions in response to comments from these groups, the HCRMP was published in June 1989.

The highest priority task of the HCRL is to conduct cultural resource reviews, pursuant to Section 106 of the NHPA, for each proposed ground-disturbing or major building alteration/demolition project on the Hanford Site. During the first 11 months of FY 1989, Hanford contractors requested 107 Section 106 reviews. Seventeen of these requests required archaeological surveys. The surveys completed before September 1 covered a total of 91.5 ha and resulted in the discovery of seven prehistoric archaeological sites and one historic archaeological site. Projects were relocated to avoid any potential impact to two sites, one located in the vicinity of the Hanford Solid Waste Landfill and the other near the 300 Area. Site $45 B N 163$ has been identified as potentially eligible for the National Register, and a finding of effect for the 300 Area Treated Effluent Disposal Facility will be prepared in early FY 1990.

The second priority task is a monitoring program designed to determine the current condition of cultural resource sites and to establish whether the DOE-RL's cultural resource management and protection policies are effective. 
Following procedures established in the HCRMP, staff monitored the condition of 40 sites including six cemeteries, 15 sites contained within properties listed on the National Register of Historic Places, and 19 sites not so listed. Five conclusions were drawn from observations made during the first year's monitoring: 1) cemetery sites show the effects only of natural erosive processes, with the exception of site $45 \mathrm{BN} 157 \mathrm{~b}$, which until it was recently fenced was periodically looted by relic collectors, 2) with the exception of a fire lane cut across National Register site 45BN149, site activities are having little direct impact on sites within the Hanford Site security fence, 3) archaeological sites within the security fence show no evidence of recent illegal digging; however, indications are that surface collection of artifacts continues, 4) areas outside the security fence, particularly those near roads and boat launches, are being impacted by relic collectors, who have been digging into intact portions of some sites, and 5) livestock are damaging archaeological sites in Franklin County, as indicated by increased erosion of heavily trampled shoreline areas.

Based on these observations, the HCRL makes the following recommendations. 1) Except for site 45BN157b, which needs and has received protection in the form of a cyclone fence, cemeteries can continue to be left alone. They should, however, be subject to surveillance by security personnel. 2) Damage to site 45BN149 demonstrates the need to revise procedures for Section 106 compliance. 3) The apparently continued practice of collecting artifacts from the surface of sites by Hanford workers demonstrates the need for an education program on cultural resource laws and values. 4) Increased surveillance of sites on the Franklin and Grant County shorelines is badly needed to reduce the activities of relic collectors and enforce the Archaeological Resources Protection Act 5) Action should be taken to mitigate stock damage to sites that are in Franklin County.

The third priority set by the HCRMP, following compliance guidelines in the Archaeological Resources Protection Act, is to establish a curation system for artifacts and associated records. The first step in planning for artifact and records curation is to ascertain the location of collections, which was a task set for FY 1989. Collections have been located at the University of Idaho, Washington State University, Mid-Columbia Archaeological Society in Richland, Washington, and the home of a Moxee City resident. All curators of these collections have agreed to cooperate with HCRL in assessing curation needs for these materials.

The fourth priority task is evaluation of cultural resources for possible nomination to the National Register of Historic Places. Evaluation procedures were conducted for three properties during FY 1989. Two of these, the Hanford B Reactor and the Gable Mountain/Gable Butte Cultural District are believed to be eligible, and nomination documents have been prepared and submitted to DOE-RL for action. Evaluation is under way for the Wahluke Archaeological District, 
a group of two sites previously nominated to the National Register but rejected for lack of information. Sites in the proposed Gable Mountain/Gable Butte Cultural District were inspected, and five were found to be potentially eligible for the National Register. Subsurface testing, which is required for archaeological evaluations, was conducted at the Wahluke site with assistance from Central Washington University. The site was found to contain a pithouse village dating back at least 1100 years and a campsite that may date between 4000 and 6000 years. Data analysis is not yet complete, but preliminary findings show strong indications of scientific significance for this site. Subsurface tests will be needed at at least one other site.

The fifth task is public education. The education program, which was planned in FY 1989, consists of three parts, targeting elementary and middle school students, secondary school students, and the general public. Implementation of this plan was begun and included discussions with curriculum committees of school districts in the Tri-Cities area, preparation of a draft brochure on cultural resources management at Hanford by PNL's public relations staff, lectures to five adult organizations, and minor assistance with the DOE-RL's Native American Awareness Week.

The lowest priority task is the archaeological survey of undeveloped areas of the Hanford Site, as required by Section 110 of the NHPA. The HCRMP specifies that a $10 \%$ stratified random sample of site lands will be surveyed in the next 5 years to refine an existing model of archaeological site distributions. Because of the low priority of this task and the high level of effort required for other tasks this fiscal year, only $1 \mathrm{mi}^{2}\left(2.6 \mathrm{~km}^{2}\right)$ could be surveyed in FY 1989. Sixteen survey plots, each with an area of $1 / 16 \mathrm{mi}^{2}\left(0.16 \mathrm{~km}^{2}\right)$, were located in stabilized dunes and in a variety of environments near the foot of a mountainous area. Plots in stabilized dunes contained only one isolated artifact, whereas plots in mountain slopes and nearby settings contained a variety of prehistoric and historic archaeological sites and isolated artifacts. 

CONTENTS

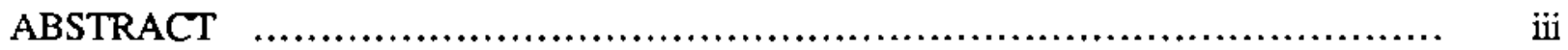

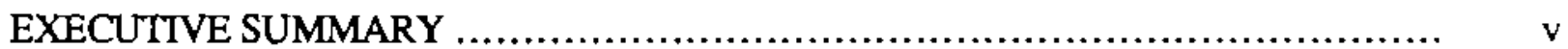

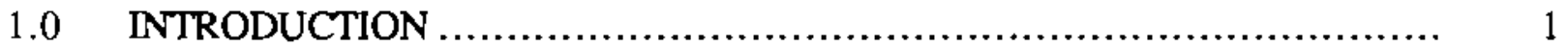

2.0 THE HANFORD CULTURAL RESOURCES MANAGEMENT PLAN ........... 3

$3.0 \quad$ SECTION 106 COMPLIANCE REVIEWS ................................. 5

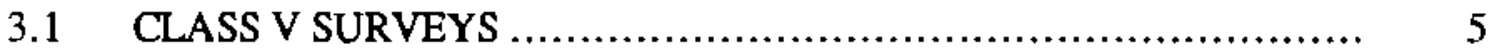

3.2 CULTURAL RESOURCES FOUND ................................. 7

4.0 THE MONTTORING PROGRAM: VERIFY, EVALUATE AND DOCUMENT THE CONDITION OF CULTURAL RESOURCES AS A BASELINE FOR MANAGEMENT; MONITOR CONDITION OF HISTORIC PROPERTIES ...... 9

4.1 CEMETERY SITES ................................................... 13

4.2 SITES LISTED ON THE NATIONAL REGISTER......................... 13

4.3 SITES NOT LISTED ON THE NATIONAL REGISTER ................. 14

4.4 CONCLUSIONS AND RECOMMENDATIONS ......................... 15

5.0 THE CURATION PROGRAM: LOCATE COLLECTIONS AND RECORDS FROM AUTHORIZED ARCHAEOLOGICAL INVESTIGATIONS AT THE HANFORD SITE

6.0 EVALUATION OF KNOWN CULTURAL RESOURCE SITES

FOR ELIGIBILITY TO THE NATIONAL REGISTER OF

HISTORIC PLACES.

6.1 HANFORD B REACTOR .......................................... 19

6.2 GABLE MOUNTAIN/GABLE BUTTE CULTURAL DISTRICT.......... 21

6.3 WAHLUKE ARCHAEOLOGICAL DISTRICT ......................... 22

7.0 THE PUBLIC EDUCATION PROGRAM ...................................... 29

$8.0 \quad$ SECTION 110 SURVEYS ............................................... 31

$9.0 \quad$ REFERENCES CITED ................................................... 35

APPENDIX A - SECTION 106 REVIEWS CONDUCTED AT THE HANFORD SITE IN FY 1989

A.I 
APPENDIX B - CULTURAL RESOURCES MONTTORING OBSERVATIONS FOR THE FY 1989 MONITORING CYCLE .........................

B.1

APPENDIX C - RANDOMLY SELECTED SURVEY PLOTS INVESTIGATED IN FY 1989

C. 1 


\section{FIGURES}

3.1 Locations of Class V Section 106 Reviews ................................... 6

4.1 Locations of Archaeological Sites Monitored in Fiscal Year 1989.................... 11

6.1 Locations of Cultural Resources Evaluated in Fiscal Year 1989 .................. 20

8.1 Locations of Sample Plots Surveyed for Section 110 Compliance ................. 32

\section{TABLES}

1.1 Priority Listing of Tasks Performed by the Hanford Cultural

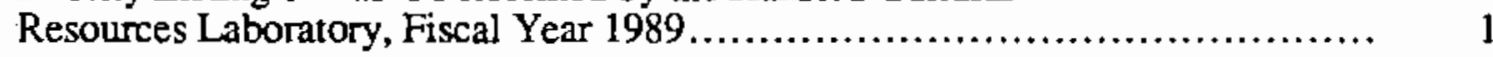

4.1 Results of Fiscal Year 1989 Archaeological Site Monitoring.......................... 10

5.1 Current Status of Archaeological Collections From the Hanford Site............. 17

6.1 Test Pits Excavated at Site 45GR306b: Placement and Findings ................ 26 
".

:

$-$

$\therefore$

. 


\subsection{INTRODUCTION}

The Hanford Cultural Resources Laboratory (HCRL) was established by the U.S. Department of Energy-Richland Operations (DOE-RL) in 1987 as part of Pacific Northwest Laboratory (PNL). The HCRL provides support for managing the archaeological, historical, and cultural resources of the Hanford Site, Washington, in a manner consistent with the National Historic Preservation Act (NHPA) of 1966, the Archaeological Resources Protection Act of 1979, and the American Indian Religious Freedom Act of 1978.

During the 1988 fiscal year (FY), the HCRL prepared a draft plan for managing the cultural resources of the Hanford Site that, among other things, established a prioritized list of tasks to be undertaken to bring the DOE-RL into compliance with federal statutes, regulations, and guidelines (see Section 2.0 of this report). Although the plan was not finalized until 1989, the list of tasks (Table 1.1) was used to guide cultural resources management activities during FY 1989.

This report is structured according to the priorities listed in Table 1.1. Each task is discussed in a separate section, except for Tasks 3 and 4 , which are combined because they are identical in tactical terms. Each section includes an explanation of the task and a description of the tactics used in performing it, as appropriate. Results of the task or the products of task performance are then described. Supporing data and descriprive detail for task 2 and tasks 3 and 4 combined are presented in Appendixes A through $\mathrm{C}$, respectively.

IABLE 1.1. Priority Listing of Tasks Performed by the Hanford Culnural Resources Laboratory, Fiscal Year 1989

Priority

1 (a)

2

3

4
Task Descripcion
Complete and publish Hanford Cultural Resources Management Plan.

Conduct National Historic Preservation Act Section 106 compliance reviews.

Verify, evaluate, and document the condition of extant cultural resources as a baseline for management.

Monitor the condition of properties listed on or eligible for the National Register of Historic Places on a 3-year rotating schedule. 
TABLE 1.1. (contd)

\begin{tabular}{ll} 
Priority & \multicolumn{1}{c}{ Task Description } \\
\hline 5 & $\begin{array}{l}\text { Locate collections and records from authorized archaeological investigations of } \\
\text { the Hanford Site. }\end{array}$ \\
6 & $\begin{array}{l}\text { Evaluate known cultural resources for eligibility to the National Register of } \\
\text { Historic Places (three identified, see Section } 6.0 \text { ) }\end{array}$ \\
7 & Plan and initiate public education. \\
8 & $\begin{array}{l}\text { Evaluate current model of archaeological resource distributions by a sample } \\
\text { inventory of 10\% of site lands (initiate in this fiscal year). }\end{array}$ \\
\hline
\end{tabular}

(a) Not included in Hanford Cultural Resources Management Plan priorities listing. 


\subsection{THE HANFORD CULTURAL RESOURCES MANAGEMENT PLAN}

A major task of the Cultural Resources Project in FY 1989 was completion and publication of the Hanford Cultural Resources Management Plan [HCRMP (Chatters 1989)]. As stated in the plan's introduction, "... the [U.S. Department of Energy (DOE)] has been directed by Congress and the President to provide leadership in the preservation of prehistoric, historical, and cultural resources on lands it administers and to manage these in a spirit of stewardship for future generations. The purpose of this document is to describe how the (DOE-RL) will meet those responsibilities on the Hanford Site...."

The plan has three main sections and 10 appendixes. Section 1.0, the Introduction, states the purpose, intent, and objectives, provides summaries of the statutory requirements for cultural resources management, and briefly summarizes the Hanford Site and its cultural resources as currently understood. Section 2.0 describes the DOE mission and activities at the Hanford Site and addresses the potential past and future impact of those activities on cultural resources. Section 3.0 details the policies and procedures for managing cultural resources and considering the impact of DOE policies and projects on the free practice of traditional religions. Specific poiicies and procedures are developed for preserving historic properties, protecting historic properties, and avoiding interference with religious practice. Cultural resource management activicies through FY 1994 are planned and prioritized in the HCRMP. Appendixes A through E provide supporting and background information on laws, previous cultural resource management of the Hanford Site, regional ecology, paleoecology paleontology, human prehistory and history, and cultural resource evaluation. Other appendixes present forms for data collection and management, Washington State policies for archaeological surveys, and lists of cultural resource surveys and historic properties.

Three drafts of the HCRMP were produced in FY 1989 before the final plan was printed. The first two of these drafts were internally reviewed by DOE-RL, the State Historic Preservation Officer, and the Advisory Council for Historic Preservation. Following necessary revision, the plan went to the Wanapum, Yakima, Umatilla, Nez Perce, and Colville Indians, the National Park Service, and the U.S. Amny Corps of Engineers. Extensive revisions were made following receipt of comments from these groups, and after response to DOE-RL comments on the final draft, the final plan was published in June 1989. 
. 


\subsection{SECTION 106 COMPLIANCE REVIEWS}

As required by Section 106 of the NHPA, the DOE-RL reviews each proposed ground disturbing or building alteration/demolition project to determine if it may impact any cultural property that is listed on or eligible for the National Register of Historic Places (National Register). This is accomplished through the cultural resources review process (Chatters 1989, Section 3.1.1). For efficiency, cultural resource reviews are classified according to four criteria: 1) whether the project entails maintenance, demolition, or new construction, 2) whether the area has been previously disturbed, 3 ) whether the project involves an existing structure or building, and 4) the cultural resource sensitivity of the area in which the activity is planned. The cultural resource reviews are divided into six classes: I) maintenance in a disturbed, low-sensitivity area, II) maintenance in a disturbed, high-sensitivity area, III) new construction in a disturbed low-sensitivity area, IV) new construction in a disturbed, high-sensitivity area, V) projects involving undisturbed ground, and $\mathrm{VI}$ ) projects involving demolition or remodeling of existing structures.

During the 1989 fiscal year, up to and including September 1, 1989, Hanford contractors requested 107 cultural resource reviews (see Appendix A, Section A.1). Most of these (64) were

of the Class III and IV types, followed by Class I and II (17), Class V (17), and Class VI (3). Six reviews were literature reviews only and do not fit any of the classes. An additional 23 cases, entailing small-scale excavation to repair leaks or set posts or larger-scale excavations in alreadycleared areas, were handled with the signature of excavation permits and were not given individual case numbers.

The largest number of requests were for the 200 and 300 Areas (Figure 3.1), 37 and 30, respectively. Because the fenced portions of the 200 Areas have been surveyed intensively for cultural resources and found to contain only one significant cultural resource, Class I through IV reviews of the 200 Area were handled by reference to that finding. Class V cases were all outside the 200 Area fences. There were 22 requests for reviews of the 100 Areas and 11 for the 600 Area. The remaining requests were divided among the $400,700,1100$, and 3000 Areas.

\subsection{CLASS V SURVEYS}

Seventeen Class V reviews were requested during FY 1989, but some of them came in too late or were of such low priority that they were not completed in time for the detailed results to be included in this report (see Appendix B, Section B.2). The late arrivals will be included in the 


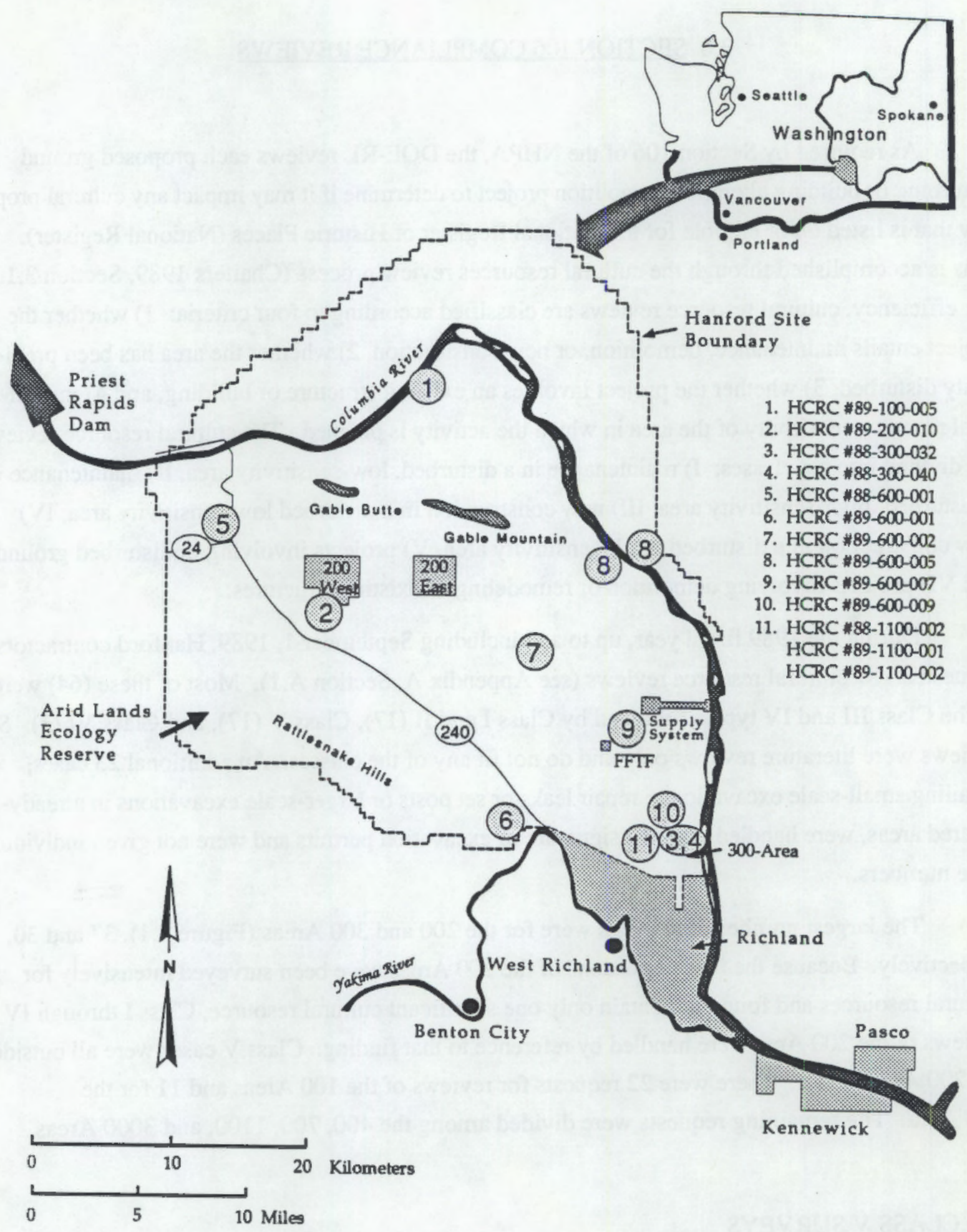

FIGURE 3.1. Locations of Class V Section 106 Reviews 
FY 1990 report. The 11 surveys that were completed covered a total of 91.5 ha and were distributed from the $100 \mathrm{~N}$ Area to the 1100 Area in North Richland (cases 88-1100-002, 89-1100-001, and 89-1100-002). Most surveys were either in the 600 Area (5) or 1100 Area (2). The largest areas covered were cases 89-200-010, which entailed survey of a 35-ha borrow area south of the 200 West Area, and case 89-600-002, a 25-ha area around the Hanford Solid Waste Landfill. All

of these surveys were located well away from the Columbia River. Cases 89-300-019 and 89300023 , which have not yet been completed, are within $400 \mathrm{~m}$ of the Columbia River, and case 89-300-019 appears to intersect a site that is eligible for the National Register. Case 88-600-011, which is under way, is a series of water improvements in the Saddle Mountains that appears to intersect several small archaeological sites.

\subsection{CULTURAL RESOURCES FOUND}

During FY 1989, HCRL staff recorded few cultural resources in areas subject to Section 106 Reviews. Three literature reviews (cases 89-100-016, 89-300-021, and 89-300-022) showed that archaeological sites existed in the project areas. These cases were overviews for environmental assessment of Comprehensive Environmental Response, Compensation, and Liability Act (CERCLA) operable units, and evaluations and findings of effect will be developed for sites within those units in FY 1989. Seven other projects contained cultural resources (cases 88-200-056, 89-200-010, 88-300-040, 89-300-019, 89-300-023, 88-600-011, 89-1100-001, and 89-1100-002).

Twelve prehistoric archaeological sites and one historic archaeological site were found. Eleven of the prehistoric sites are located on Saddle Mountain (case 89-600-011), and include six lithic (chipped stone) scatters that are stone quarrying or processing areas, and three caims. The remaining prehistoric site is located near the Hanford Solid Waste Landfill (89-600-002), and is a lithic scatter containing resharpening and thinning flakes. The historic site is a scatter of cans from around the turn of the century and is located near the 300 Area (89-300-040). Isolated artifacts occurred in six cases, and consisted of tin cans, bottles, and lithic flakes; all were collected and reside in the HCRL files. Cans and bottles were found in the 200,300, and 1100 Areas. Lithics were in the Saddle Mountains and the 300 Area. An extensive early irrigation system was found in association with homestead remains at McGee Ranch.

Projects were relocated to avoid any potential impact to the two sites in the vicinity of the Hanford Solid Waste Landfill and the 300 Area, regardless of their significance. Site 45BN163 has been identified as potentially eligible for the National Register, and a finding of effect for the 
300 Area Treated Effluent Disposal Facility will be prepared in early FY 1990. The sites on Gable Mountain are current discoveries and have not been evaluated. 


\subsection{THE MONITORING PROGRAM: VERIFY, EVALUATE AND DOCUMENT THE CONDITION OF CULTURAL RESOURCES AS A BASELINE FOR MANAGE- MENT: MONITOR CONDITION OF HISTORIC PROPERTIES}

"As manager of the Hanford Site, the DOE is assigned the stewardship of all archaeological resources, traditional use areas, paleontological deposits, and historic properties onsite. DOE-RL therefore has the responsibility for determining whether its management and protection policies are effective and when they are inadequate. To determine the impact of DOE policies and to safeguard cultural resources from destruction by natural processes or unauthorized excavation and collection, the HCRL will maintain a monitoring program" (Chatters 1989, page 3.28). That monitoring program is designed to inspect each cemetery site once a year, to inspect each site listed on the National Register at least every 3 years, and each nonlisted site every 5 years. Monitored sites that are found to be receiving natural or anthropogenic impacts will be reinspected annually, at a minimum. Monitoring results are used in planning for cultural resource site management and protection and in identifying needs for corrective measures.

In addition to monitoring specified in the HCRMP, the HCRL will more frequently monitor areas within 5 miles $(8 \mathrm{~km})$ of the proposed Vernita boat launch, located just upstream of the Vernita Bridge in Grant County, Washington, through a memorandum of agreement with the State Historic Preservation Officer and Advisory Council for Historic Preservation. These sites will be visited before construction of the proposed launch and, if constructed, 6 months after the launch is built, once a year for 3 years, then every 3 years thereafter.

To select the sample of sites to be inspected in FY 1989, laboratory staff first identified cemeteries known to exist on the Hanford Site. Staff then stratified the remaining National Register sites according to site type as listed on the State of Washington Archaeological Site Record. Sites were listed as housepit sites, open camps, and fishing stations, following definitions employed by Rice (1968a, b) for these categories. Site age was not included as a category because so few of the site records contain this kind of information. A random $33 \%$ sample of National Register sites was chosen. An additional group of sites not yet listed on the National Register, but situated within the area potentially frequented by boaters using the proposed Vernita boat launch, was added to the list. Including the cemeteries, this made a list of 42 sites.

At the time of this writing (September 1989), 40 sites had been inspected (Figure 4.1), but the two cemeteries located on islands had not yet been visited. Monitoring results are described below on a site-by-site basis, and findings are summarized in Table 4.1. 


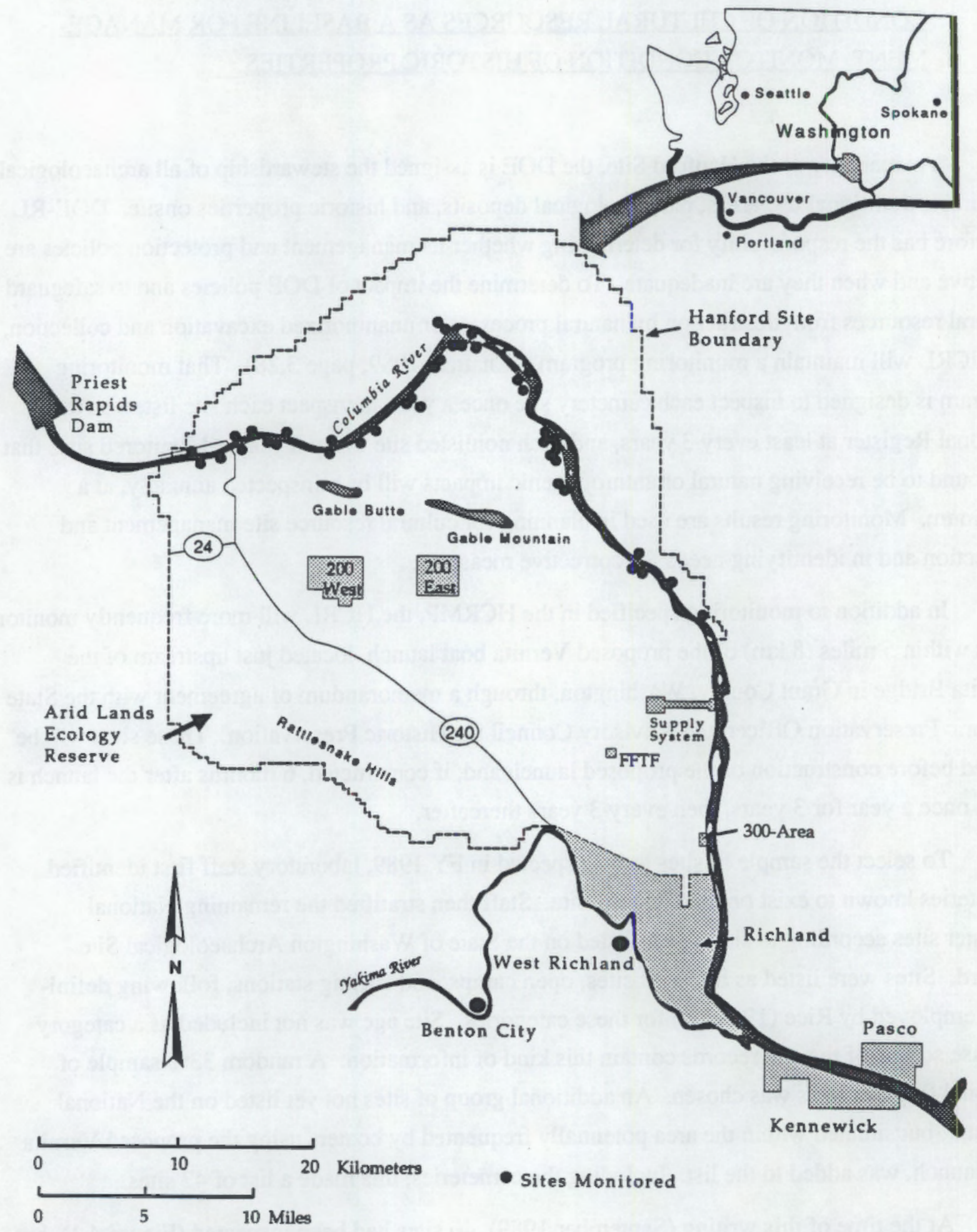

FIGURE 4.1. Locations of Archaeological Sites Monitored in Fiscal Year 1989 
TABLE 4.1. Results of Fiscal Year 1989 Archaeological Site Monitoring

\begin{tabular}{|c|c|c|c|}
\hline Site No. & Monitoring Group & $\begin{array}{c}\text { Type of } \\
\text { Disturbance(a) }^{(a)}\end{array}$ & Conclusion, Recommendation \\
\hline $45 \mathrm{BN} 118$ & National Register & none & (b) \\
\hline $45 \mathrm{BN} 119$ & National Register & $\mathrm{SC}$ & (b) \\
\hline $45 \mathrm{BN} 121$ & National Register & $\mathrm{D}$ & Revise National Register listing \\
\hline $45 \mathrm{BN} 124$ & Cemetery & none & (b) \\
\hline $45 \mathrm{BN} 125$ & National Register & $\mathrm{SC}$ (minor) & (b) \\
\hline $45 B N 126$ & National Register & none & (b) \\
\hline $45 B N 128$ & Cemetery & WE & (b) \\
\hline $45 \mathrm{BN} 132$ & National Register & none & Remove from National Register \\
\hline $45 \mathrm{BN} 133$ & National Register & none & (b) \\
\hline $45 \mathrm{BN} 134$ & National Register & none & Remove from National Register \\
\hline $45 B N 139$ & Cemetery & none & (b) \\
\hline $45 B N 140$ & National Register & WE, SC(?) & Include in 45BN139 \\
\hline $45 \mathrm{BN} 144$ & Non-Register & none & Not significant \\
\hline $45 \mathrm{BN} 145$ & Non-Register & $\mathrm{SC}(?)$ & Not significant \\
\hline $45 \mathrm{BN} 146$ & Non-Register & WE & Test for significance \\
\hline $45 \mathrm{BN} 147$ & Non-Register & none & Not a site, remove from listings \\
\hline $45 B N 148$ & Non-Register & Soil borrowing & $80 \%$ destroyed, not significant \\
\hline $45 \mathrm{BN} 149$ & National Register & TP, DOE bulldozing & Fill pits, end bulldozing of site \\
\hline $45 \mathrm{BN} 151$ & Cemetery & none & (b) \\
\hline $45 \mathrm{BN} 152$ & Non-Register & $\mathrm{SC}$ & Not significant \\
\hline $45 \mathrm{BN} 153$ & Non-Register & $\mathrm{SC}(?)$ & Not significant \\
\hline $45 \mathrm{BN} 154$ & Non-Register & none & Not a site, remove from listings \\
\hline
\end{tabular}


TABLE 4.1. (contd)

\begin{tabular}{|c|c|c|c|}
\hline Site No. & Monitoring Group & $\begin{array}{l}\text { Type of } \\
\text { Disturbance (a) }\end{array}$ & Conclusion, Recommendation \\
\hline $45 \mathrm{BN} 155$ & Non-Register & none & Not a site, remove from listings \\
\hline $45 \mathrm{BN} 156$ & Non-Register & none & Not a site, remove from listings \\
\hline $45 \mathrm{BN} 157 \mathrm{a}$ & Non-Register & SC, CD, WE, PR & Nominate, protect, surveillance \\
\hline $45 \mathrm{BN} 157 \mathrm{~b}$ & Cemetery & $\mathrm{SC}, \mathrm{CD}, \mathrm{WE}, \mathrm{PR}$ & Nominate, protect, surveillance \\
\hline $45 \mathrm{BN} 178$ & Non-Register & SC, WE & Add to National Register \\
\hline $45 \mathrm{BN} 179$ & Non-Register & see $45 B N 149$ & Part of 45BN149 on National Register \\
\hline $45 \mathrm{BN} 180$ & Non-Register & see $45 B N 149$ & Part of $45 B$ BN149 on National Register \\
\hline $45 \mathrm{FR} 258$ & National Register & SC, CD, WE, SD & Surveillance, cattle fencing \\
\hline $45 \mathrm{FR} 260$ & National Register & SC, CD, WE, SD & Surveillance, cattle fencing \\
\hline $45 F R 262$ & National Register & SC & Surveillance \\
\hline $45 \mathrm{GR} 302 \mathrm{a}$ & National Register & TP, SC, CD & Surveillance, full pits \\
\hline 45GR306b & Non-Register & SC(?), WE, PR & Surveillance, nominate \\
\hline $45 \mathrm{GR} 306 \mathrm{c}$ & Cemetery & WE & Incorrect location, is at $45 \mathrm{BN} 306 \mathrm{a} / \mathrm{b}$ \\
\hline 45GR315 & Non-Register & $\begin{array}{l}\text { none, actual site } \\
\text { shows } C D\end{array}$ & Incorrect location, survetllance \\
\hline $45 \mathrm{GR} 316$ & Non-Register & none & Test for significance \\
\hline 45GR317 & National Register & $\mathrm{SC}, \mathrm{CD}$ & Surveillance \\
\hline 45GR318 & Non-Register & SC, WE & Not significant \\
\hline 45GR320 & Non-Register & none & Not significant \\
\hline
\end{tabular}

(a) Abbreviations for disturbance types are $\mathrm{CD}$, collector digging; SC, surface collecting; TP, open test pits; SD, stock damage; WE, wind erosion; D, digging apparently not by collectors, PR, public recreation.

(b) No recommendation. 


\subsection{CEMETERY SITES}

The purpose of inspecting sites identified as cemeteries by Wanapum Elders or through the discovery of graves is to evaluate their condition and document any erosion, vandalism, looting, or unintentional disturbance. Such information can be used as background for developing and maintaining effective measures for protecting these sites.

Six cemetery sites have been inspected: 45BN124, 45BN128, 45BN139, 45BN151, 45BN157b, and 45BN306c. Results of inspections are shown in Table 4.1; details are presented in Appendix B.

Monitoring results show that site renumbering or map corrections are needed for two cemeteries. Site 45 GR $306 \mathrm{c}$ has been almost entirely deflated by wind, yet no sign of human remains or grave markers can be found. Caims marking graves do occur in dunes at 45BN306a and 45BN306b, which more closely fit the description given by Krieger (1928) for the cemetery location. The cemetery numbered 45BN139 is marked on maps approximately $300 \mathrm{~m}$ south of its actual location, and it is contiguous with $45 \mathrm{BN} 140$, which does contain human remains and grave marker materials.

Damage to cemeteries varies, but in general sites in this category are undisturbed by modem human activity. Wind erosion is the most severe type of damage observed. Sites 45BN124 and 45BN151 are in stabilized dunes and exhibit no erosion, but erosion is evident at 45BN306, and wind erosion is severe enough to expose human remains at 45BN128 and 45BN139. Smallscale looting was evident at 45BN157b, which is located in an area used heavily by the public for a variety of activities. Action was therefore taken in cooperation with representa-tives of the Wanapum band and Yakima Tribe to construct a cyclone fence around the cemetery.

\subsection{SITES LISTED ON THE NATIONAL REGISTER}

Seventeen of the monitored sites (Figure 4.1), in addition to five of the cemeteries, are listed on the National Register of Historic Places or are included in larger sites that are listed. These listed sites include the Savage Island (45BN118, 45BN119, 45FR258, 45FR260, 45FR262), Hanford North (45BN125, 45BN126, 45BN132, 45BN133, 45BN134), Locke Island (45BN140, 45GR302a), and Ryegrass Archaeological Districts [45BN149 (and enclosed 45BN179, 45BN180)], and the Hanford Island (45BN121) and Paris (45GR317) sites. Concerns were slightly different in the case of National Register listings. Evidence of damage, looting, or erosion were again of primary importance, but whether the site could be found and actually 
appeared to contain data of scientific significance were also important. In some cases, absence of the site as described or the lack of evidence for scientific significance may warrant removal of a site from the National Register.

Observations made by HCRL staff are presented in Appendix B (Section B.2). Two sites (45BN132 and 45BN134) either could not be found or lacked sufficient scientific potential to justify National Register listing. Another, the Hanford Island site (45BN121), was found to be two sites, and neither of them was the housepit village described in nomination materials. Rather than being a late prehistoric village, these sites are much older campsites used for limited activities.

Most of the sites inside the Hanford Site security fence in Benton County exhibited no signs of damage, except for minor wind erosion and probable surface collection by site workers (Table 4.1). Site 45BN149, which includes two other sites (45BN179 and 45BN180) within its boundaries, shows no sign of collection activity, but it is the only site monitored that has been damaged directly by Site activity. A 15-m-wide firebreak was cut in 1989 across the upper terrace of the site, damaging an unknown amount of a probable Cascade Phase component [ca 4500-7000 year B.P. (B.P. is radiocarbon year before 1950 A.D.)]. The firebreak was cut without a prior Section 106 review. In addition to this recent damage, there is a large archaeological excavation pit, dating back to the 1970s, that has not been backfilled. If this pit continues to remain open, the site may be damaged by bank slumping and possibly by relic collector activities.

Damage to National Register sites is more severe on the Franklin and Grant County sides of the Columbia River and on the one island inspected. Sites in the Savage Island Archaeological District (45FR258 and 45FR260) are being damaged both by relic collectors and livestock. Collector excavations, occur in intact portions of 45FR258. Surface disturbance by these two agents is promoting wind erosion. Test pits remain open at 45GR302a, and this site and the Paris site (45GR317) show signs of continuing relic collector activity. Surface collecting and digging are evident in both cases, although the damage is confined to deflated areas along the bank of the Columbia River.

\subsection{SITES NOT LISTED ON THE NATIONAL REGISTER}

Sixteen sites that have not been nominated to the National Register were also reviewed in 1989 (Table 4.1). Five of these are in the proposed Wahluke Archaeological District (Rice 1980), at which reevaluation activities were conducted during this fiscal year. These sites are discussed in Section 6.3. The remaining sites were inspected to determine if they did in fact exist, to determine what damage, if any, they had received, and to screen sites for their National Register potential. 
Sites found to have potential will be evaluated in more detail in the near future. Appendix B (Section B.3) presents the results of monitoring.

Based on monitoring observations, one site (45BN157a) should be nominated to the National Register, and test excavation should be conducted at two others (45BN146 and 45GR316) to obtain data for evaluation and possible nomination to the National Register. The remaining sites are either nonsignificant or could not be found. Four sites (45BN147, 45BN154, 45BN156, and 45GR315) do not appear to exist. No artifacts of any kind were found at or near mapped locations. A site was found approximately $400 \mathrm{~m}$ upstream from $45 \mathrm{BN} 315$, but the site did not resemble its description and must be considered a new site.

Damage to this group of sites is similar in kind and geographic distribution to the National Register group. Sites inside the security fence surrounding the Hanford Site showed signs of surface collection. Things such as net sinkers, which had been reported by the discovery team, could not be found. No other damage was evident inside the fence, but sites outside the fence consistently showed signs of relic collector activity. Site 45BN157a was the most severely damaged, but recent digging was more evident at the newly discovered site near the nonexistent $45 \mathrm{BN} 315$.

\subsection{CONCLUSIONS AND RECOMMENDATIONS}

Five conclusions can readily be drawn from observations made during the first year's (FY 1989) monitoring. First, cemetery sites are experiencing only natural erosive processes, with one exception. Second, Hanford Site activity is having little direct impact on sites within the security fence in Benton County. One exception to this, site 45BN149, is a case of an activity slipping through the Section 106 review process. Second, Hanford Site workers have not been disturbing archaeological sites by digging for artifacts, but they appear to have been collecting artifacts from the surface to the extent that projectile points and net sinkers that were so often reported in 1968 are rarely seen. Third, areas outside the security fence, particularly those near roads and boat launches, are being impacted by relic hunters to a minor degree, including some digging activity. Worst affected are the Paris site (45GR317, 45BN258 in the Savage Island Archaeological District) and the Vernita site (45BN157a and b). Last, livestock, notably cattle, are damaging archaeological sites in Franklin County; their trampling is causing increased erosion.

Cemeteries should be subject to frequent surveillance by security personnel. Cemeteries are all located in dunes, which makes them predisposed to wind erosion. Wind erosion is a natural process, and we believe those who buried their compatriots in dunes were knowledgeable enough 
to expect wind to expose them eventually. It does not seem reasonable to attempt to alter or halt this process. However, erosion that exposes artifacts and bones may invite looting, so surveillance of wind-eroded cemeteries is necessary. However, protection is essential for 45BN157b. This protection was implemented in the form of cyclone fencing and posting.

Damage to site 45BN149 identifies a need to revise the Section 106 process during FY 1990. We have learned that the cutting of fire trails is not subject to excavation permitting, which has been the only vehicle thus far used to initiate and implement the Section 106 review process.

The fact that Hanford workers apparently continue to collect artifacts from the surface of sites demonstrates that an education program is needed and should be directed at people who frequent the field. Such a program is part of the HCRMP and should be implemented as soon as possible. Radiation monitors, biologists, and security personnel are most active in the field, and should be the first included in of this effort.

The most serious problem among the five noted is the continued activity of relic collectors at sites both on and potentially eligible for the National Register. Most severely affected sites are outside the security area, and all except 45BN157 are on land managed for the DOE by other agencies. Access to the sites is sometimes obtained by road, but more often by boat. The most severely affected site, 45FR268, is approachable by road. Boat launches are near sites 45GR302a and 45GR317, which are the second most seriously damaged. Sites approachable only by boat are being exploited by digging along the shoreline, where it appears collectors believe themselves less subject to discovery. Stepped-up surveillance of these sites, and of the Franklin and Grant County shorelines in general, is needed.

Finally, action should be taken to mitigate stock damage in the parts of the site that are in Franklin County. Stock fences excluding animal access to site areas would be the most expedient way to effect such mitigation. 


\subsection{THE CURATION PROGRAM: LOCATE COLLECTIONS AND RECORDS FROM AUTHORIZED ARCHAEOLOGICAL INVESTIGATIONS AT THE HANFORD SITE}

An important goal set by the HCRMP, following guidelines of the Archaeological Resources Protection Act, is to establish a curation system for artifacts and records pertaining to cultural resources. The first step in the process of planning for artifact and records curation is to ascertain the location of collections, which was the task set for FY 1989.

Much of the necessary information was contained in Rice (1980), but in confirming locations described in that report, HCRL staff found that some materials have been relocated and additional collections have been made since Rice wrote his summary. Results of the curation efforts for FY 1989 are summarized in Table 5.1. Cooperation with HCRL in estimating the volume and types of materials has been requested from and granted by all of the current curators of the collections.

TABLE 5.1. Current Status of Archaeological Collections From the Hanford Site(a)

\begin{tabular}{llll}
\hline \multicolumn{1}{c}{ Site(s) } & \multicolumn{1}{c}{ Location of Collections } & Curator & Coop(b) \\
$\begin{array}{l}\text { Ben-Franklin Survey, } \\
\text { numerous sites }\end{array}$ & $\begin{array}{l}\text { Mid-Columbia Archaeological } \\
\text { Society, Richland, Washington }\end{array}$ & $\begin{array}{l}\text { Kim Simmons, } \\
\text { Director }\end{array}$ & yes \\
$\begin{array}{l}\text { Test Excavated } \\
\text { 45BN149, 45GR302a, } \\
\text { 45GR306b, 45GR317 }\end{array}$ & $\begin{array}{l}\text { Mid-Columbia Archaeological } \\
\text { Society, Richland, Washington }\end{array}$ & $\begin{array}{l}\text { Kim Simmons, } \\
\text { Director }\end{array}$ & yes \\
$\begin{array}{l}\text { Test Excavated 45BN157a, } \\
\text { Vernita Site }\end{array}$ & $\begin{array}{l}\text { Home of Kenneth DenBeste, } \\
\text { Moxee City, Washington }\end{array}$ & Kenneth DenBeste & yes \\
$\begin{array}{l}\text { Test Excavated 45BN179, } \\
\text { 45BN180, 45BN257, } \\
\text { 45FR266h }\end{array}$ & $\begin{array}{l}\text { Laboratory of Anthropology, } \\
\text { University of Idaho, Moscow, } \\
\text { Idaho }\end{array}$ & Leo Flynn & yes \\
$\begin{array}{l}\text { Test Excavated 45BN307; } \\
\text { surveys post-1986 }\end{array}$ & $\begin{array}{l}\text { Hanford Cultural Resources } \\
\text { Laboratory }\end{array}$ & Natalie Cadoret & yes \\
\hline
\end{tabular}

(a) Collections made after federal acquisition of the site in 1943.

(b) Curator has agreed to cooperate with HCRL in assessing curation needs. 



\subsection{EVALUATION OF KNOWN CULTURAL RESOURCE SITES FOR ELIGIBILITY TO THE NATIONAL REGISTER OF HISTORIC PLACES}

Section 110 of the NHPA and Executive Order 11593 require the DOE to evaluate all cultural resources under its management for their eligibility to the National Register. Evaluation procedures were conducted for three sites during FY 1989. Two of these sites, the Hanford B Reactor and the Gable Mountain/Gable Butte Cultural District (Figure 6.1) are believed to be eligible, and nomination documents have been prepared. These nomination materials have been

provided to the DOE-RL, which has submitted them to the Washington State Historic Preservation Officer for comment.

The third site, located in the Wahluke Archaeological District, was nominated to the National Register in the mid-1970s, but the nomination was returned for lack of information. Sites in the proposed district were visited to relocate and assess their condition and determine if their inclusion in a district, was appropriate. Site 45GR302b (Wahluke site), the principal site in the district, was mapped and subsurface tests were conducted to gather data to support statements of scientific significance. Data analysis is not yet complete, but preliminary findings show strong indications of scientific significance for five sites within the Wahluke Archaeological District.

Excerpts from nomination forms for the Hanford B Reactor and Gable Mountain/Gable Butte Cultural District and a description of activities in the Wahluke Archaeological District are presented below.

\subsection{HANFORD B REACTOR}

National Register nomination documents for the Hanford B Reactor were prepared in April 1989. The Hanford B Reactor is a single-pass, water-cooled, plutonium production reactor that was constructed during World War II as part of the Manhattan Project. Construction of the reactor began in 1943, and the facility produced fissionable material for national defense until its deactivation in 1968. It is situated on a terrace of glacial flood gravels $0.8 \mathrm{~km}$ south of the Columbia River and $5.6 \mathrm{~km}$ east of Washington State Highway 240 at the Vernita Bridge crossing.

The Hanford B Reactor is housed inside the $105 \mathrm{~B}$ reactor containment building in the $100 \mathrm{~B} / \mathrm{C}$ Area of the Hanford Site. The containment building is surrounded by various support 


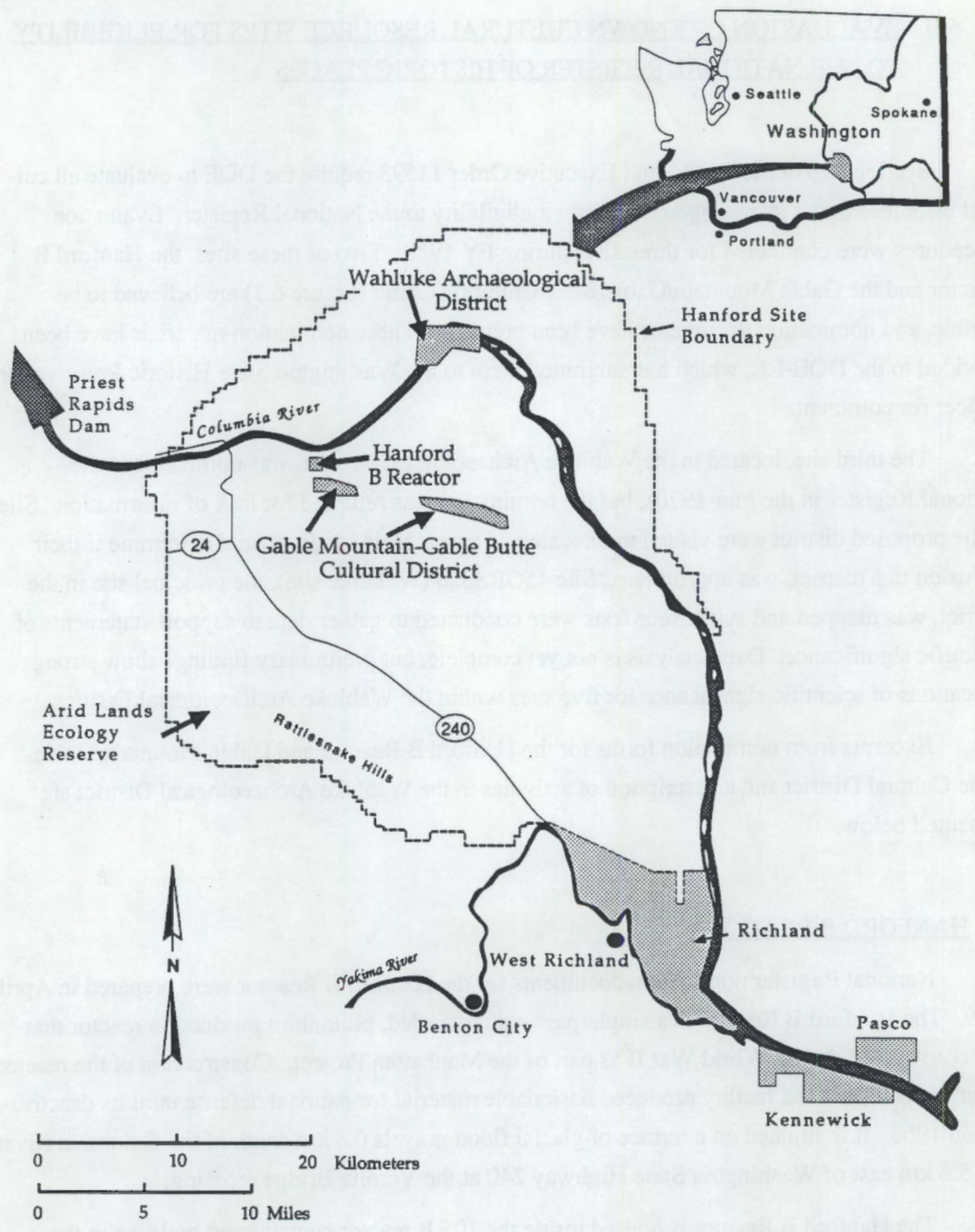

FIGURE 6.1. Locations of Cultural Resources Evaluated in Fiscal Year 1989 
structures, which were not included in the nomination and are scheduled for demolition in the near future. The $105 \mathrm{~B}$ Building and its contents are intact, with no significant changes made since deactivation in 1968.

The Hanford B Reactor meets criteria for the National Register under criterion (a) [36 CFR 60.4]: having been associated with events that contributed to the broad patterns of history. The Hanford B Reactor contributed to history in three ways: 1) it was the first largescale reactor to attain full power and hence represents the beginning of the nuclear age, 2) it produced the plutonium that was used in the first nuclear explosion and thus represents the beginning of the era of nuclear weaponry, which has had a profound impact on geopolitical history, and 3) it was a part of the Manhattan Project, which in just 3 years took nuclear weaponry from the realm of theory into practice and ended World War II. The Hanford B Reactor produced the plutonium used in the bomb dropped on Nagasaki, which led to the Japanese surrender. Given these effects on the course of history, it is reasonable to conclude that the impact of the construction and use of the Hanford B Reactor has been as great as any other event in recent history.

\subsection{GABLE MOUNTAIN/GABLE BUTTE CULTURAL DISTRICT}

The Gable Mountain and Gable Butte are remnant features of an eroded basaltic anticline that extend in three clusters for about $16 \mathrm{~km}$ along an east-west axis in the central part of the Hanford Site. They stand out as distinctive promontories of the natural world, ranging in width from $0.4 \mathrm{~km}$ to $1.6 \mathrm{~km}$ and standing up to $180 \mathrm{~m}$ above the floor of the Pasco Basin.

Two themes, religious activity and hunting, are represented by the archaeological remains. Archaeological features include isolated and clustered rock cairns along elevated ridges and knobs (16 sites), with occasional rock alignments, talus pits, and lithic scatters at the base and along the flanks of the Gable Butte (seven sites). Isolated projectile points are common, and represent the Cascade (8000-4500 B.P.) and Harder (2500 B.P.-protohistoric) phases in the local chronology (Leonhardy and Rice 1970).

The natural configuration of rocky ridges, sheltered hollows, isolated knobs, and mesa tops provides a setting that possesses more cultural importance to the native peoples of central Washington and norihern Oregon than do the identifiable vestiges of the rock caims and hunting sites. Gable Mountain in particular plays an important role in their cosmology, and has been the site of religious ceremonies and spirit quest activity within the past 2 years. 
Eligibility was supported under two criteria. Under criterion (d), the district contains information important for understanding the history of Plateau Indian religion and hunting practices. Under criterion (a), the site is a traditional use area that played an important part in the Native American history of the Columbia Basin region. It is the latter criterion that highlights the site's significance.

Since Indian people regard Gable Mountain and Gable Butte as sacred sites, the complete landforms are included in the cultural district, not just the distribution of rock caims or the huntingrelated sites. Also, whereas an anthropologist might recognize the rock cairns as significant, only Indian people are likely to know the totality of significant features present in this district. Consultation with Indian religious leaders will aid in the management of the cultural sites within this district.

\subsection{WAHLUKE ARCHAEOLOGICAL DISTRICT}

The Wahluke Archaeological District was proposed by Rice based on the concept of site complex, which is defined as "geographically associated sites which are of the same general age, which are functionally diversified, and which may have been used concomitantly for different purposes by a single group of people" (Rice 1968a, page 23). The original nomination of this district included 10 sites: 45BN141 through 45BN147 and 45GR306a through 45GR306c. Seven of these sites were revisited in FY 1989, and subsurface tests were conducted at 45BN306b; results of inspections and preliminary results of testing are described below.

\subsubsection{Inspection of Sites Listed in the District}

Sites 45BN144 through 45BN147 and 45GR306a through 45GR306c were revisited and their existence, age, and scientific potential reconsidered. Before evaluation is complete, sites 45BN141 through 45BN143 will also need to be reviewed. Descriptions of the sites and inspections are discussed in the following text.

\section{BN144}

Rice originally described this as a campsite $100 \mathrm{~m}$ long and $30 \mathrm{~m}$ wide, containing concentrations of heat-modified rock (FCR), notched sinkers, a hammer stone, and an anvil stone. The site was identified in the fall of 1988 and consisted of very few scattered FCR on a deflated cobble surface adjacent to a remnant of early Holocene alluvium. No sinkers or other tools were observed, and there was nothing to indicate site age. 


\section{BN145}

The description of this site is nearly identical to 45BN144 except that artifacts included cobble tools, hopper mortar bases, and comer-notched projectile points. The 1988 visit found less than a dozen FCR, an anvil stone, and three cobble cores loosely scattered along the deflated edge of a 100-m-long remnant of dune-capped alluvium. No cultural material was visible in the remnant itself.

\section{BN146}

Rice (1968a) described this as a group of seven or eight housepits and scattered FCR concentrations on a shight bench downstream of and opposite the Wahluke site. Cobble tools, notched sinkers, a drill, and a pestle were found.

In 1988 , the site was easily relocated approximately $100 \mathrm{~m}$ upstream of the location illustrated by Rice. It is in a roughly triangular remnant of an older alluvial terrace that has been almost entirely eroded away. Fluvial sand is capped by 30 to $80 \mathrm{~cm}$ of eolian sand; artifacts occur at the contact between the two. Artifact deposits consist of 2-to 4-m-diameter concentrations of large (ca 15-cm-diameter), oxidized, occasionally fragmented, granitic FCR associated with cobble cores, anvil stones, and a small amount of cryptocrystalline detritis. FCR outnumber other artifacts by $50: 1$, whereas flakes and cobble cores are present in equal numbers. Rock concentrations are widely spaced away from the river, but are coalesced near the shoreline. Bone is present, in good condition, and includes remains of ungulates, salmon, and canids. One mussel shell was seen. There is no indication of housepits.

The low diversity of artifacts and low proportion of chipped stone to FCR is indicative of a site where a limited number of activities were performed, possibly associated with salmon fishing and processing. FCR concentrations are reminiscent of those seen at 45GR316, which is attributable to the Frenchman Springs Phase.

\section{$45 \mathrm{BN} 147$}

This site is described as a cluster of housepits on an eroded river bar opposite the Wahluke site. No artifacts were found in association with it during the original survey (Rice 1968a). The HCRL staff easily located the place reported to contain the site, but no evidence of an archaeological site was found. Depressions interpreted as housepits are wind- and water-scoured hollows in a remnant of early or mid-Holocene floodplain. 


\section{GR306a}

This site is originally described as a campsite consisting of extensive concentrations of FCR and shell, plus a variety of cobble tools, notched sinkers, pestles, and hopper mortar bases. Much of the site is covered by or lies in dunes. The eastern portion of the site was inspected in June 1989, and the existence of numerous FCR and shell concentrations and hopper mortar bases or anvils was confirmed. Two significant additional observations are the presence of concentrations of large stones on dune surfaces, and the fact that shell primarily is eroded from either deep in dune sand or beneath the dunes. Rock concentrations on dune surfaces are evidence for graves (see discussion of 45BN139 in Section 4.1), which probably mark the cemetery partially excavated by Krieger (1928). Evidence that shells are being eroded or brought up by rodents from within or beneath the dunes represents an earlier occupation of the site than do the graves. Gonidea and Margaritifera are both present in and among the shells, which leads us to conclude that the earlier occupation may belong to the Cascade Phase (Lyman 1980).

\subsubsection{Wahluke Site (45GR306b): Reinspection and Test Excavation}

Wahluke is reported by Rice (1968a) as a 450-m-long, 150-m-wide campsite containing at least 25 housepits; much of which has been deflated by wind erosion. Excavations were first conducted at the site by Herbert Krieger of the Smithsonian Institute, who reported finding rockrimmed house pits and numerous graves (Krieger 1928). Artifacts he recovered date primarily to the Cayuse Phase, although there are older artifacts in Smithsonian collections from the site (Rice 1980). In personal conversation, Rice reported to HCRL staff that he and the Mid-Columbia Archaeological Society (MCAS) had excavated test pits in the eastern portion of the site, finding the cultural deposit to be less than $1 \mathrm{~m}$ deep and containing no incontrovertible evidence for housepits.

Evaluation work at the Wahluke site during FY 1989 included surface inspection, mapping, systematic auger testing, and test excavation. Work was conducted by faculty and students from Central Washington University, Ellensburg, Washington, under the direction of the HCRL. Analysis of the results of that work is under way and will be completed during the first quarter of FY 1990. Therefore, the following description of activities and findings is preliminary.

\section{Surface Observations}

The site extends approximately $400 \mathrm{~m}$ along a high, sand-capped gravel terrace on the left bank of the Columbia River near the beginning of the White Bluffs. Its south end is covered by a series of sand dunes and is more properly linked to site 45GR306a, to which it is essentially 
identical. At the northern end of the dunes is a deep blowout containing piles of mussel shells and large numbers of FCR, cobble cores, and flakes. The assemblage appears to represent the Cascade Phase.

Immediately east of the blowout (downriver) is a narrow terrace of gravel covered by alluvial and eolian sand. The first $50 \mathrm{~m}$ of this terrace is a homestead area, with locust trees and historic trash, that was leveled during the Hanford Site cleanup of the 1970s. Downriver of the homestead is an area approximately $150 \mathrm{~m}$ long and $30 \mathrm{~m}$ wide of pits and dirt piles left by relic collectors. Pits tend to be less than $1 \mathrm{~m}$ deep, a surface skimming of sorts. The disturbances have been eroded by wind and now resemble a mass of tiny dunes and blowouts. Tens of thousands of FCR, cryptocrystalline flakes, and bone fragments are present, along with many hopper mortar bases, cores, flake tools, and other artifacts. Projectile points found on the surface of this area are attributable to the Cayuse Phase. Below this terrace is a gravel flat that was formerly within the flood channel of the Columbia River. Collectors' pits pock mark this area as well.

Downriver of the disturbed area is a slightly higher terrace similar to the first, but showing much less disturbance. It appears to consist of a gravel base, near the elevation of the lower terrace surface, that has been capped by eolian or parafluvial sand to a depth of less than $1 \mathrm{~m}$. Pits and depressions are common and appear to be cellar pits from the homestead era, test pits excavated by the MCAS in the early 1970s, and prehistoric housepits. Shell bits are scattered over the surface near the terrace bank, and FCR, hopper mortar bases, cobble tools, and flakes are common.

Despite extensive evidence of earlier relic collecting, there is little indication that the activity continues today. There were no recently excavated pits, and the presence on the surface of such artifacts as net sinkers and projectile points indicates that surface collecting is not intensive. There is evidence, however, that members of the public make unauthorized visits. Campfires have been built on shell piles in the dune area, and string lines and lashed poles on the locust trees show that modern hunters have butchered game on the site

\section{Subsurface Tests}

Seven test pits were excavated in selected areas of the Wahluke site to sample the spatial variability of artifact deposits and investigate specific, apparently cultural features (Table 6.1). In placing the pits, a particular effon was made to avoid areas disturbed by relic collectors. Pits were ordinarily $1 \mathrm{~m}^{2}$, except for Test Unit $1 / 2$, which was a 1- by 2 -m pit. Pits were excavated in arbitrary 10-cm levels; all excavated material was passed through 6-mm wire cloth screening, and all bone, chipped stone, shell, and tools were saved. FCR was counted, weighed, and discarded in the field. Profiles were drawn of at least one wall of each pit. 
TABLE 6.1. Test Pits Excavated at Site 45GR306b: Placement and Findings

Test

Unit Location

Findings

$1 / 2 \quad$ Sand dune area

3 South edge of the homestead area

4 Level undisturbed plot in center of collectordisturbed area

$5 \quad$ Northeast edge of looted terrace

6 Center of a suspected housepit, upper terrace

7 Outer edge of upper terrace in shell concentration

$8 \quad$ East edge of housepit tested in pit 6 , placed to determine pit size, profile
Surficial artifacts; pit closed at $1 \mathrm{~m}$ because of wall collapse

Historic debris at surface, prehistoric strata of Cayuse Phase to depth of $1.4 \mathrm{~m}$

Multiple house/living floors to $2.1 \mathrm{~m}$; bone preservation excellent, including salmon, dog, deer, rabbits; coprolites present; age estimated at last 2500 years; radiocarbon date $1150 \pm 110$ years B.P.

Dense, organic-rich midden to $50 \mathrm{~cm}$

Housepit floor at $90 \mathrm{~cm}$, containing well-preserved fishbone, charcoal; radiocarbon date $290 \pm 80$ years B.P.

Early (Cascade Phase?) shell midden at $70 \mathrm{~cm}$

Artifacts confined to upper $30 \mathrm{~cm}$; housepit edge not found

Subsurface tests in the dune area of the site produced only surficial FCR and a few flakes and animal bone fragments. In the lower terrace, however, where the homestead and collectordisturbed areas occur, cultural layers were found at varying depths. Test Unit 5 was the shallowest and contained a homogenized organic-rich midden to $50 \mathrm{~cm}$ underlain by sterile sand. Test Unit 3, at the opposite end of the terrace, contained three levels of high artifact density, including cryptocrystalline flakes, bone, and projectile points. Projectile points were primarily attributable to the Cayuse Phase, although one specimen from the deepest level may belong to the Frenchman Springs Phase. Animal remains were primarily those of large herbivores, possibly including bison. Test Unit 4 was the most productive test pit. Located in a rectangular undisturbed area that had probably been under a barn, it contained seven superimposed, charcoal-rich layers to a depth of $2.1 \mathrm{~m}$. These layers, which were tentatively interpreted as housepit floors, were separated by layers of wind- or water-deposited sand and contained chipped stone artifacts that indicate occupation during the last 2500 years. Bone was well preserved and included primarily salmon, 
along with rabbit, deer, and dog. The dismembered forelimb of a dog was found in the third floor from the bottom, apparently buried beneath a cluster of stones.

Excavation in the upper terrace revealed two components. The younger component, exposed in Test Units 6 and 8, consisted of housepits and a low-density artifact deposit in areas between the housepits. One house floor that was investigated in Test Unit 6 contained charcoal and superbly preserved salmon bone. The high quality of bone preservation is suggestive of recent age, which has been confirmed by a radiocarbon date of $290 \pm 80$ years B.P. The second component consists of an extensive shell midden at least 10 by $20 \mathrm{~m}$ in extent, as indicated by the surface distribution of shell fragments. Shells encountered in Test Unit 7 were in a 10-cm-thick layer between 70 and $90 \mathrm{~cm}$ below surface, and consisted of very thick, large specimens of Margaritifera falcata. Specimens were very friable. The size, thickness, and condition of the shells are evidence for great age, perhaps in the range of 4000 to 6000 years B.P.

Samples of charcoal from four floors in Test Unit 4, the lowest artifact concentration in Test Unit 3, the house floor in Test Unit 6, and the shell layer in Test Unit 7 have been submitted for dating to Beta Analytic, Inc. of Coral Gables, Florida. Preliminary results from two samples are shown in Table 6.1.

\subsubsection{Preliminary Evaluation}

The Wahluke Archaeological District contains 10 identified sites. The centerpiece of the district, site 45GR306b, despite having been severely looted by relic collectors, contains extensive, undisturbed archaeological components of at least two and possibly three archaeological phases. site 45GR3066 contains housepits that are as young as a few hundred years to as old as 2000 years or more; the housepits contain an abundance of well-preserved animal remains and charred-plant material. The deepest housepit investigated even contained numerous coprolites, which, if human, are among the best sources of dietary information available. There is potential in the site for scientific data relating to population sizes, domestic activity, adaptive strategies, and subsistence, to name a few. Older components may have similar potentials.

Site 45GR306c does not appear to be a cemetery, as do the upper components of site 45BN306a. The latter site also contains a deeply buried component of what may be the Frenchman Springs or Cascade Phase.

Site 45BN146 appears to be a site of special activity dating to the Frenchman Springs Phase (or perhaps later). The site's good faunal preservation and large undisturbed areas could provide scientific data on the activity represented. Test excavation is needed at this site to establish its age and to clarify its function. 
Site 45BN147 is not an archaeological site, and 45BN144 and 45BN145 are apparently deflated (and perhaps surface collected) to the point of having lost their scientific value. Although site 45BN145 may date to the Cayuse Phase, 45BN144 cannot be dated. Sites 45BN141, $45 \mathrm{BN} 142$, and 45BN143 remain to be evaluated.

Based on these findings, the Wahluke Archaeological District, as originally conceived, does not fit the definition of a site complex. It consists of sites containing components of various ages and is not, as originally thought, a group of Cayuse Phase occupations of differing functions. Its composition should be reevaluated. At the very least, sites 45GR306c, 45BN147, 45BN145, and 45BN144 should be omitted. 


\subsection{THE PUBLIC EDUCATION PROGRAM}

This activity, planned in the first quarter of FY 1989, consists of three parts targeting elementary and middle school students, secondary school students, and the general public. The elementary/middle school effort is directed at 4 th and 8 th grades, as part of their Washington State history curriculum, and will emphasize Indian cultures, archaeological interpretations, and conservation. The secondary school effort will be part of the DOE Sharing Science with Schools program and will emphasize scientific values of cultural resources and preservation problems. The work directed at the general public includes public relations efforts to inform people about cultural resources management at Hanford, including news releases, as appropriate, and a brochure prepared by the Office of Hanford Environment; public lectures on cultural resources management at Hanford and on regional prehistory; and various activities related to Native American awareness.

Implementation of this plan was begun in FY 1989 (it began much earlier on an informal basis). During this fiscal year, HCRL staff spoke to one high school class and are scheduled to take part in Sharing Science with Schools beginning in fall 1989. Curriculum coordinators at Pasco, Richland, and Kennewick school districts were contacted to arrange meetings with social studies teachers to discuss how best to present material to primary students, but meetings were never finalized. A different strategy will be used in the future. On the general public front, a brochure is being prepared on cultural resources management at Hanford by PNL's Public Relations staff in collaboration with the HCRL. Lectures have been presented to five public groups (the Atomic City Kiwanis, the Lakeside Gem and Mineral Club, the Northwest Section of the Society for Range Management, the Northwest Science Association, and the Richland Friends of the Library), and the HCRL assisted the DOE-RL with its Native American Awareness Week (September 18-22, 1989). 



\subsection{SECTION 110 SURVEYS}

Section 110 of the NHPA specifies that federal agencies must identify all historic properties on lands under their administration. Because this has rarely been practicable, given the scale of federal holdings, the Advisory Council for Historic Preservation has added to its list of acceptable identification procedures the process of predictive modeling. A predictive model estimates the number and distribution of different types of cultural resources based either on a theoretical conception of human behavior (deductive model) or a knowledge of the distribution of cultural resources on a statistically selected sample of the agency's lands (see Chatters 1989; Section 3.1.1).

The DOE-RL is already using a simple predictive model to conduct cultural resource reviews of lands that have been classified as either low or high sensitivity, depending on their geographic setting and the likelihood that cultural resources occur in that setting. The classification is based on ethnohistorical information and on the results of archaeological reconnaissance and survey efforts previously conducted on the Hanford Site and the nearby, ecologically similar Pasco Basin. Although this model is currently in use, it has not yet been validated.

The HCRMP specifies that predictive model validation and refinement will include a 10\% survey of site lands, an analysis of the cultural properties found during that survey in temporal, functional, and distributional terms, and an extrapolation from these data of the number and distribution of different kinds of cultural resources throughout the area. This work is to be conducted over a period of 6 years, of which FY 1989 was the first.

A stratified random sampling strategy has been used to select $10 \%\left(143 \mathrm{~km}^{2}\right)$ of Hanford Site lands for survey. The study area was first divided into parts (environmental zones) that were assumed or demonstrated to be internally homogeneous for environmental characteristics pertinent to human use. The characteristics considered in stratifying the area were topography, surface hydrology, soils, and known distributions of archaeological resources. Once the environments had been defined, the entire site was divided into sample units of $16 \mathrm{ha}$, which were then numbered and sampled randomly for each environmental zone.

Only 16 plots were surveyed in FY 1989 (see Figure 8.1 and Appendix C), amounting to $1 \mathrm{~m}^{2}$ of area, or $0.2 \%$ of the entire Hanford Site. This is an insufficient area from which to draw conclusions, but some preliminary observations are warranted. Seven plots were located in the stable dune environmental zone, which is generally low lying and flat. These plots contained one 


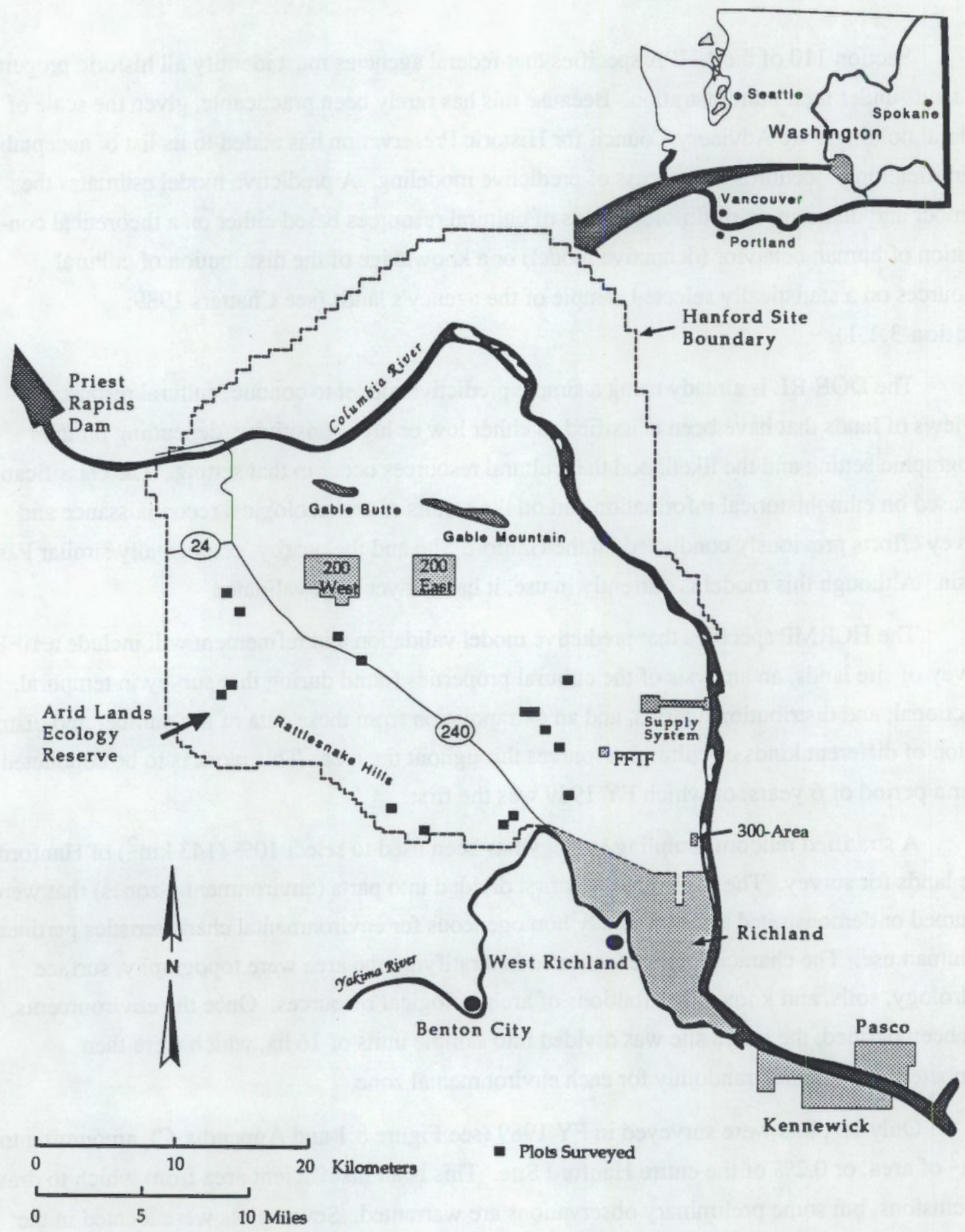

FIGURE 8.1. Locations of Sample Plots Surveyed for Section 110 Compliance 
flake of cryptocrystalline silica. Plots located in other environmental zones, particularly on the slopes of Rattlesnake Mountain, contained a variety of prehistoric sites, and isolates any trash left by late nineteenth- or early twentieth-century Euroamerican occupants. 



\subsection{REFERENCES CITED}

Chatters, J. C. editor. 1989. Hanford Cultural Resources Management Plan. PNL-6942, Pacific Northwest Laboratory, Richland, Washington.

Krieger, H. W. 1928. "A Prehistoric Pithouse Village Site at Wahluke, Grant County, Washington." In Proceedings of the United States National Museum 73:1-29, U.S. Government Printing Office, Washington, D.C.

Leonhardy, F. C. and D. G. Rice. 1970. "A Proposed Culture Typology for the Lower Snake River Region, Southeastern Washington." Northwest Anthropological Research Notes 4:1-29.

Lyman, R. L. 1980. "Freshwater Bivalve Molluscs in Southern Plateau Prehistory: A Discussion and Description of Three Genera." Northwest Science 54:121-136.

Rice, D. G. 1968a. Archaeological Reconnaissance: Ben Franklin Reservoir Area, 1968. Washington State University Laboratory of Anthropology, Pullman, Washington.

Rice, D. G. 1968b. Archaeological Reconnaissance of the Hanford Atomic Works. Washington State University Laboratory of Anthropology, Pullman, Washington.

Rice, D. G. 1980. Overview of Cultural Resources on the Hanford Reservation in South-central Washington State. U.S. Department of Energy, Richland Operations, Richland, Washington. 



\author{
APPENDIX A \\ SECTION 106 REVIEWS CONDUCTED \\ AT THE HANFORD SITE IN FY 1989
}




\section{APPENDIX A}

\section{SECTION 106 REVIEWS CONDUCTED AT THE HANFORD SITE INFY 1989}

This appendix presents a complete listing of Section 106 cultural resource reviews requested of the HCRL by Hanford Site contractors and the DOE-RL during FY 1989 (Table A.1). It then provides descriptions of those Class $\mathrm{V}$ reviews which were completed during the fiscal year (Section A.2). These reviews do not include cases 88-600-011, 89-200-023, 89-200-025, 89$300-019,89-300-023$, or 89-600-010, which were not yet completed at the time this report was written.

\section{A.1 SECTION 106 REVIEWS REOUESTED DURING FY 1989}

A complete listing of Section 106 reviews requested by Hanford Site contractors or the DOE-RL between October 1, 1988, and September 1, 1989, is presented in Table A.1. 
TABLE A.1. FY 1989 Cultural Resource Reviews

\begin{tabular}{|c|c|c|c|c|c|}
\hline Case \# & Classification & Project Name & $\begin{array}{l}\text { Monitoring } \\
\text { Required? }\end{array}$ & $\begin{array}{l}\text { Cultural } \\
\text { Resources? }\end{array}$ & Significant? \\
\hline $88-100-021$ & III & 117-C Exhaust Filter Building Demolition & No & No & \\
\hline $88-100-022$ & III & 105-F Fuel Basin Storage Monitoring Well & No & No & \\
\hline $88-100-023$ & III & 115-B/C Gas Recirc. Fclty and Tunnel Demo. & No & No & \\
\hline 88-100-024 & III & 116-B Crib Remediation Demonstration Project & No & No & \\
\hline 88-100-025 & I & 100-N Fire Hydrant Replacement & No & No & \\
\hline $89-100-001$ & I & 183-H Fire Supply Line Repair & No & No & \\
\hline $89-100-002$ & I & 105-F Fire Supply Line Repair & No & No & \\
\hline $89-100-003$ & I & 183-C Fire Hydrant Removal & No & No & \\
\hline 89-100-004 & I & 183-B Fire Hydrant Repair & No & No & \\
\hline $89-100-005$ & v & 1324N/NA Surface Impoundment & No & No & \\
\hline $89-100+-006$ & III & Groundwater Monitoring Well Tanks & No & No & \\
\hline $89-100+-007$ & III & Integrated Voice and Data Telecom. System & No & No & \\
\hline $89-100-008$ & 1 & 100-N Fire Main Repair & No & No & \\
\hline 89-100-009 & III & 100-KE \& 100-D UST Removal & No & No & \\
\hline 89-100-010 & I & 183-B Fireline Repair & No & No & \\
\hline $89-100-011$ & I & 100-B Fire Hydrant \#19 Repair & No & No & \\
\hline $89-100-012$ & III & 100-K 1908 Outfall Line & No & No & \\
\hline $89-100-013$ & III & Hanford Switching Substation Microwave Tower & No & No & \\
\hline $89-100+-014$ & III & Hanford Infrastructure UST & No & No & \\
\hline $89-100-015$ & NA & 100 HR-1 CERCLA Overview & NA & No & \\
\hline $89-100-016$ & NA & 100 HR-3 CERCLA Overview & NA & Yes & National Register Properties \\
\hline $89-100-017$ & NA & 100-DR-1 CERCLA Overview & NA & No & \\
\hline $88-200-050$ & III & UO3 Double Wide Excavation & No & No & \\
\hline $88-200-051$ & III & Liner Leachate System Test & No & No & \\
\hline $88-200-052$ & III & 272 E Jib Crane & No & No & \\
\hline $88-200-053$ & III & Environmental Hot Cell Expansion & No & No & \\
\hline $88-200-054$ & I & 609A Water Leak Repair & No & No & \\
\hline $88-200-055$ & III & Grout Treatment Multipurpose Facility & No & No & \\
\hline $88-200-056$ & $\mathrm{v}$ & Surface Environmental Monitoring & No & 2 Isolates & No \\
\hline $88-200-057$ & III & A24 Crib Postholes & No & No & \\
\hline $88-200-058$ & I,III & S Plant Mobile Office Facilities Service Instal. & No & No & \\
\hline $88-200-059$ & I & AR Vault Second Filter System & No & No & \\
\hline $88-200-060$ & III & 242-A Evaporator/Crystalizer Upgrade & No & No & \\
\hline $88-200-061$ & III & W-020 Cathodic Protection Upgrade & No & No & \\
\hline $89-200-001$ & III & 204-S Contamination Cleanup & No & No & \\
\hline
\end{tabular}




\begin{tabular}{|c|c|c|c|c|c|}
\hline Case \# & Classification & Project Name & $\begin{array}{l}\text { Monitoring } \\
\text { Required? }\end{array}$ & $\begin{array}{l}\text { Cultural } \\
\text { Resources? }\end{array}$ & Significant? \\
\hline $89-200-002$ & VI & 2704-E Facility Demolition & No & No & \\
\hline $89-200-003$ & III & W-017 Groundwater Monitoring Wells & No & No & \\
\hline $89-200-004$ & III & Asbestos Cleanup by $2715 \mathrm{EC}$ and $2707 \mathrm{E}$ & No & No & \\
\hline $89-200-005$ & III & Special Naval Disposal Trench Expansion & No & No & \\
\hline $89-200-006$ & III,V & $218-W-2 A$ and $216-T-18$ Cleanup & No & No & \\
\hline $89-200-007$ & III & Hexone Remediation Demonstration & No & No & \\
\hline 89-200-008 & III & Low-Level Burial Grounds Permit Application & No & No & \\
\hline 89-200-009 & III & C-049, Caustic Storage Modification & No & No & \\
\hline $89-200-010$ & $\mathbf{v}$ & Interim Stabilization $216-S-5$ and $216-S-6$ Cribs & No & Isolate & No \\
\hline 89-200-011 & III & 272 Double-Wide Installation & No & No & \\
\hline $89-200-012$ & III & 2721 EA Double-Wide & No & No & \\
\hline $89-200-013$ & III & T Plant PAX & No & No & \\
\hline 89-200-014 & III & T Plant Railroad Cut Asphalt Removal & No & No & \\
\hline $89-200-015$ & III & 284E Triple-Wide Mobile Office Facility & No & No & \\
\hline $89-200-016$ & III & W-086, 217 CR Compressor Upgrade & No & No & \\
\hline 89-200-017 & III & 2713-W-25 Site Geotechnical Investigation & No & No & \\
\hline $89-200-018$ & III & MO-351 Trailer Installation & No & No & \\
\hline $89-200-109$ & III & B-691 Laundry Facilities HVAL Upgrade & No & No & \\
\hline $89-200-020$ & III & $216-Z-4 / 6 / 10 / 17$ Stabilization & No & No & \\
\hline $89-200-021$ & III & T Plant Tunnel Cleanup & No & No & \\
\hline $89-200-022$ & III & 241-C and 241-T Tank Farm GMW Installations & No & No & \\
\hline $89-200-023$ & v & 200 Area Treated Effluent Disposal Facility & $?$ & Not surveyed yet & \\
\hline $89-200-024$ & NA & 200-BP-1 CERCLA Overview & No & No & \\
\hline $89-200-025$ & v & W-017 Ground water Mon. Wells-Modular Tanks & $?$ & Not surveyed yet & \\
\hline $88-300-035$ & IV & 399-1-16D Well Abandonment & Yes & No & \\
\hline $88-300-036$ & III & Fiber Optic Cable Installation & No & No & \\
\hline $88-300-037$ & IV & B-524 Electrical Distribution, Phase I & Yes & No & \\
\hline $88-300-038$ & I & 382 Bld Steamline Repair & No & No & \\
\hline 88-300-039 & I & Crossbuck Post Replacement & No & No & \\
\hline $88-300-040$ & v & 618-2, 618-3 Burial Ground Stabilization & Yes & Historic Site, Isolate & No \\
\hline $88-300-041$ & I & Sewer line Repair, 326-TR-2 & No & No & \\
\hline $89-300-001$ & II & Fire Hydrant FH-49 Repair & No & No & \\
\hline $89-300-002$ & III & Piping Main Water Supply Modification & No & No & \\
\hline $89-300-003$ & I & 366 Steamline Repair & No & No & \\
\hline $89-300-004$ & III & French Drain/Storm Sewer Line & No & No & \\
\hline
\end{tabular}


TABLE A.1. (contd)

\begin{tabular}{|c|c|c|c|c|c|}
\hline Case \# & Classification & Project Name & $\begin{array}{l}\text { Monitoring } \\
\text { Required? }\end{array}$ & $\begin{array}{l}\text { Cultural } \\
\text { Resources? }\end{array}$ & Significant? \\
\hline 89-300-005 & III & 300 Fiber North Project & No & No & \\
\hline $89-300-006$ & IV & 326 Boiler Installation & No & No & \\
\hline $89-300-007$ & III & 3763TR1/3764 Bldg PVC Conduit & No & No & \\
\hline 89-300-008 & III & Decommissioning of 311 Methanol Facility & No & No & \\
\hline $89-300-009$ & III & D-394, Hazardous Waste Treatment Facility & No & No & \\
\hline $89-300-010$ & III & D-388, ES\&H Improvements, 326 Building & No & No & \\
\hline $89-300-011$ & IV & Tissue Depository, 331 Bldg & Yes & No & \\
\hline $89-300-012$ & I,III & 306E Double-Wide Installation & No & No & \\
\hline $89-300-013$ & III & 350 Sandblast Area Fence & No & No & \\
\hline 89-300-014 & VI & 3707-S Bldg Demolition & No & No & \\
\hline $89-300-015$ & III & FMIT Trailer 9 and 10 Modifications & No & No & \\
\hline 89-300-016 & III, VI & Tritium Driver Fabrication Facilities Mod. & Yes & No & \\
\hline 89-300-017 & I & Fire Water Supply S-306-2 and 3 Repair & No & No & \\
\hline $89-300-018$ & III,IV & L-046, 300 Area Emergency Electrical System & Yes & No & \\
\hline $89-300-019$ & v & 300 Area Treated Effluent Disposal Facility & Yes & Site & Potential \\
\hline $89-300-020$ & IV & 315 Building Fence Installation & Yes & No & \\
\hline $89-300-021$ & NA & 300-FF-1 CERCLA Overview & NA & Sites & Eligible for National Register \\
\hline $89-300-022$ & NA & 300-FF-5 CERCLA Overview & NA & Sites & Eligible for National Register \\
\hline $89-300-023$ & $\mathbf{v}$ & MSRC & No & $\begin{array}{l}\text { Historic } \\
\text { Isolates }\end{array}$ & No \\
\hline $89-400-001$ & III & 400 Area Security Barrier Modifications & No & No & \\
\hline $88-600-011$ & v & Saddle Mountain Water Improvement & $?$ & 6 Sites; 5 Isolates & Potential \\
\hline $89-600-001$ & III,V & FMCS Extension to ALE & No & No & \\
\hline $89-600-002$ & v & Hanford Solid Waste Landfill Lysimeter & No & Site & Potential \\
\hline $89-600-003$ & IV & Gable Mountain Security Gate & No & No & \\
\hline $89-600-004$ & III & Gas Bottle Storage, $6652 \mathrm{H}$ Bldg & No & No & \\
\hline $89-600-005$ & V & Groundwater Detection, Hanford Site Boundary & No & No & \\
\hline $89-600-006$ & III & 615 Bldg Pole Anchor & No & No & \\
\hline $89-600-007$ & v & 400 Area Sewage Treatment System Upgrades & No & No & \\
\hline $89-600-008$ & III & 622-R Bldg and Gravel Pit UST Removal & No & No & \\
\hline $89-600-009$ & V,III & In-situ Vitrification Fenced Area & No & No & \\
\hline $89-600-010$ & v & Project L-006 Road Upgrade & No & No & \\
\hline $88-700-001$ & IV & 712 Building Electrical Service Upgrade & Yes & No & \\
\hline $88-700-002$ & I & 747 Bldg Excavation & No & No & \\
\hline
\end{tabular}


TABLEA.l. (contd)

\begin{tabular}{lllccc}
\hline Case \# & Classification & \multicolumn{1}{c}{ Project Name } & $\begin{array}{c}\text { Monitoring } \\
\text { Required? }\end{array}$ & $\begin{array}{l}\text { Cultural } \\
\text { Resources? }\end{array}$ \\
\hline $89-700-001$ & IV & T03 Bldg UST Removal & No & No \\
$89-1100-001$ & V & 1100 EM-1 Remedial Investigations Feasibility & No & Historic road, canal \\
$89-1100-002$ & III,V & CERCLA Groundwater Monitoring Wells & No & No \\
$89-3000-001$ & II & KEH UST Removal & No & No & No \\
\hline
\end{tabular}




\section{A. 2 CLASS V SECTION 106 REVIEWS}

The Class V Section 106 reviews conducted by the HCRL during FY 1989 are described in numerical order in the following text. For each case, descriptions are provided for the project, the surveyed area, techniques used in the survey, and survey findings. A map of the survey area is also provided. 
HCRC \#89-100-005

\title{
THE 1324-N/NA SURFACE IMPOUNDMENT/ PERCOLATION POND SOIL CHARACTERIZATION
}

\author{
Requester: Y. Sada \\ Environmental Engineering Group \\ Westinghouse Hanford Company \\ Richland, Washington 99352
}

Project Description: The proposed project will involve sampling of the existing 1324-N/NA Ponds in the $100 \mathrm{~N}$ Area of the Hanford Site (Figure A.1) and excavation of a new trench that will be sampled to obtain background measurements. The $1324 \mathrm{~N}$ Pond will be sampled at eight randomly selected locations, which will be excavated to a depth of $0.9 \mathrm{~m}$. The new trench will measure approximately $9 \mathrm{~m}$ long, $3 \mathrm{~m}$ deep, and will have a $1.5-\mathrm{m}$ bottom width. Soil samples taken randomly from the bottom area of the trench will be to a depth of $0.3 \mathrm{~m}$.

N. A. Cadoret conducted the onsite inspection of the proposed trench on March 2, 1989. The trench will be located to the east of the $155 \mathrm{~N}$ Facility and to the west of a gravel road in an area measuring approximately $30 \mathrm{~m}$ east-west by $80 \mathrm{~m}$ north-south. This area was surveyed for cultural properties in transects spaced $20 \mathrm{~m}$ apart. Vegetation onsite included cheatgrass, Sandberg's bluegrass, green rabbitbrush, knapweed, and yarrow.

Cultural Resources: No cultural resources were observed. The sediments onsite are Pleistocene river gravels with finer sediments interstitial. There is a very low potential for buried cultural properties in this setting. 


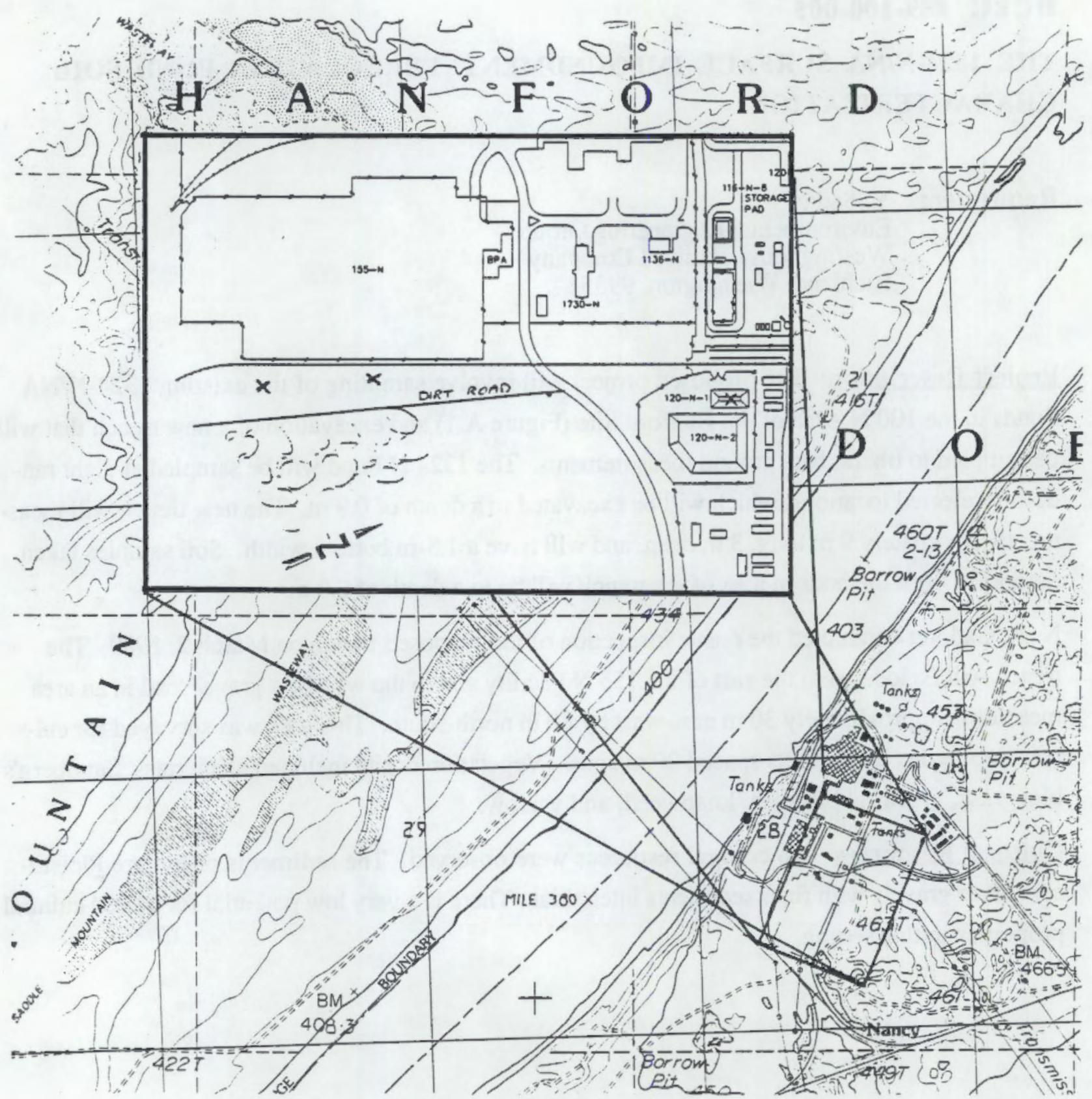

FIGURE A.1. Location of the 1324-N/NA Surface Impoundment/Percolation Pond Soil Characterization, HCRC \#89-100-005, on a Portion of the USGS Coyote Rapids Quadrangle, T 14 N, R 26 E (scale is 1:24,000, 1986 Provisional Edition) 
HCRC \#89-200-010

THE INTERIM STABILIZATION OF THE 216-S-5 AND 216-S-6 CRIBS

Requester: W. M. Hayward

Decommissioning Engineering

Westinghouse Hanford Company

Richland, Washington 99352

Project Description: The project will involve borrowing dirt from undisturbed ground to the west of an existing borrow area for use in covering the 216-S-5 and 216-S-6 cribs (see Fig-

ure A.2). A review of an area with the following coordinates was requested: W76300 to W78100 (216-U-9 backfilled ditch), N32400 to N35300.

Our literature and records review showed that no archaeological or native American cultural properties are known to be located onsite. Because the proposed borrow area is undisturbed, a pedestrian survey was necessary as part of the review. K. A. Hoover and N. A. Cadoret conducted the onsite survey on April 24, 1989. The area to the north of the dirt road (see Figure A.2) was searched for cultural properties in transects $20 \mathrm{~m}$ apart. The area to the south of the dirt road is largely disturbed by previous activities. For this reason and for safety concerns, no pedestrian survey of this area was conducted.

Cultural Resources: One historic isolated artifact, an extract bottle (\#HI-89-002), was identified in the proposed borrow area. The bottle was collected. No other cultural properties were identified. 


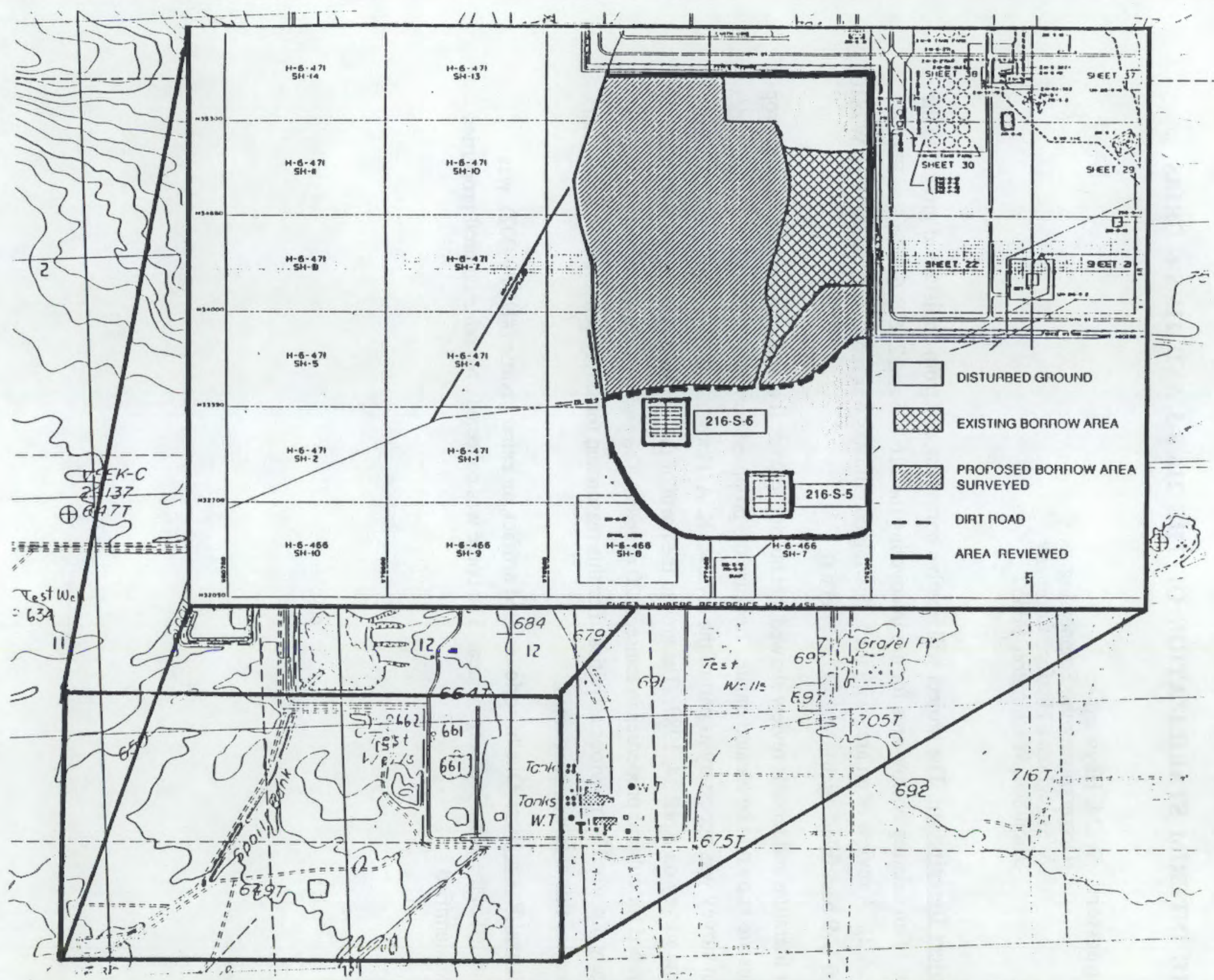

FIGURE A.2. Location of the Proposed Borrow Area for the Interim Stabilization of the 216-S-5 and 216-S-Cribs, HCRC \#89-200-010, on a Portion of the USGS Riverland and Gable Butte Quadrangles, 'T 12 and 13 N, R 25 and 26 E (scale is $1: 24,000,1986$ Provisional Edition) 
HCRC \#88-300-032

\title{
618-5 BURIAL GROUND FENCE UPGRADE
}

\author{
Requester: D. S. Kelly \\ Defense Waste Management Projects \\ Westinghouse Hanford Company \\ Richland, Washington 99352
}

Project Description: This project installed a new chain link fence around the southeast side and the northeast end of the 618-5 burial ground, which is located immediately north of the 300 Area of the Hanford Site, Washington (Figure A.3). The new fence enclosed strips of land adjacent to an existing fence around the burial ground. The newly enclosed area extended $13.6 \mathrm{~m}$ to the southeast and $37.4 \mathrm{~m}$ to the northeast of the existing fence. The fence along the southeast side was extended toward the southwest until it intercepted the fence enclosing the process sewer trench. The total, newly enclosed area was approximately $7143 \mathrm{~m}^{2}$. The fence installation required excavation to a maximum of $1.4 \mathrm{~m}$ of approximately 92 post holes with maximum diameters of $0.4 \mathrm{~m}$.

On September 6,1988, before the fence installation, a pedestrian survey of the project area was conducted by M. K. Jackson of the HCRL. Because of the project's proximity to several recorded archaeological sites, the excavation of the fence post holes was monitored by M. K. Jackson on September 21 and 22.

Cultural Resources: No prehistoric or historic cultural materials were encountered during the field inspection or were noted during monitoring. 


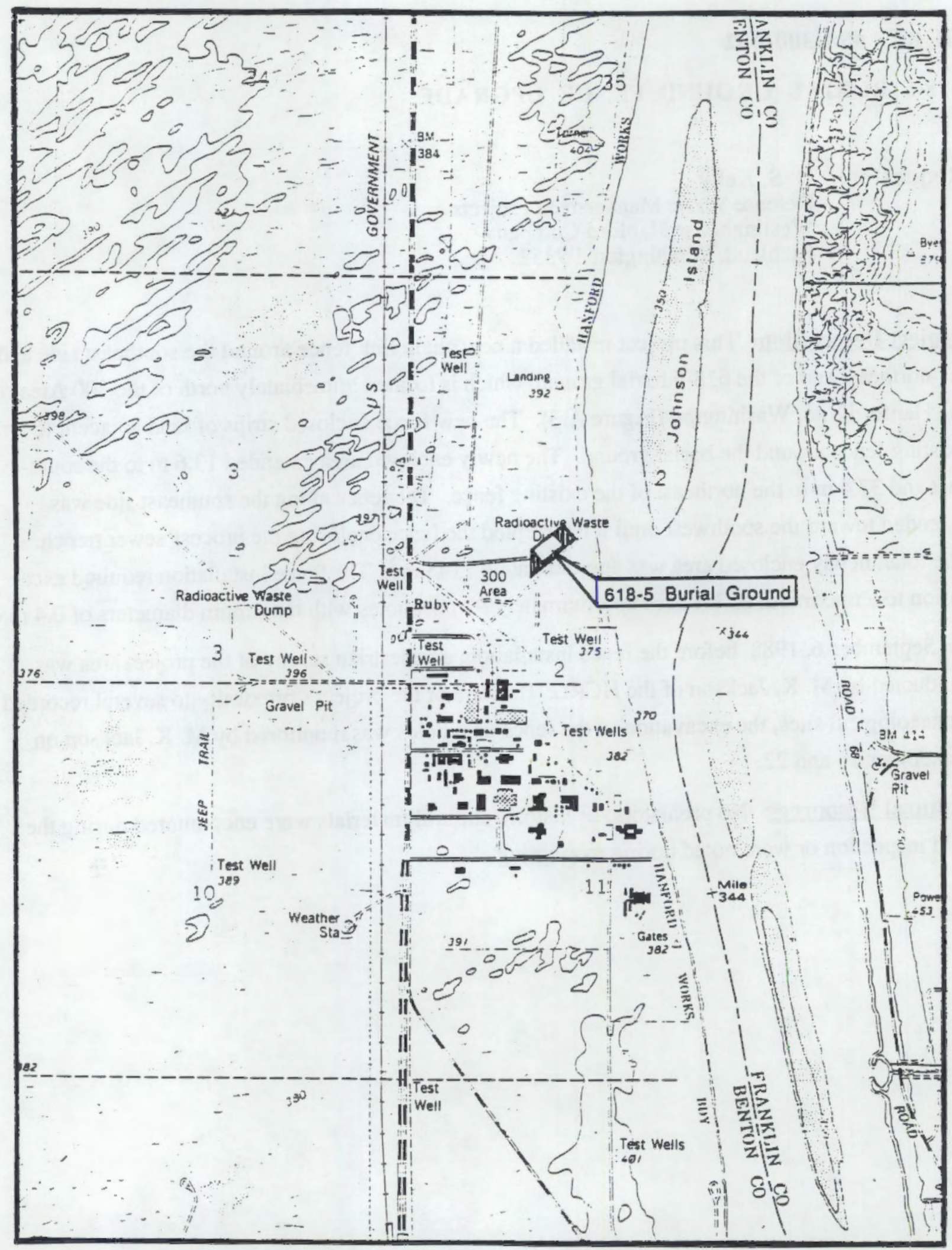

FIGURE A.3. Map Showing Area Surveyed for 618-5 Burial Ground Upgrade, USGS Richland and Wooded Island 7.5-Minute Quadrangles, 1978 (scale is $1: 24,000$ ) 
HCRC \#88-300-040

THE 618-2 AND 618-3 BURIAL GROUND STABILIZATION BORROW AREA

\author{
Requester: W. M. Hayward \\ Decommissioning Engineering \\ Westinghouse Hanford Company \\ Richland, Washington 99352
}

Project Descrintion: An area to the north of the 300 Area of the Hanford Site (Figure A.4) was proposed for use as a borrow area for the 618-2 and 618-3 burial ground stabilization. An area measuring $380 \mathrm{~m}$ east/west by $180 \mathrm{~m}$ north/south was surveyed at 20 -m intervals on January 16 , 1989.

Cultural Resources: One historic site, a late nineteenth to early twentieth century domestic trash scatter, assigned temporary site number HT-89-001, and one prehistoric isolated artifact, \#HI-89-001, were identified within the proposed borrow area The isolated artifact, an unmodified cryptocrystalline flake, was collected. The site was staked off and was not disturbed during the borrowing activities.

Our literature and records review showed that the borrow area was about $305 \mathrm{~m}$ from the closest recorded archaeological site, 45BN163. Because of the proposed borrow area's proximity to the Columbia River and to $45 \mathrm{BN} 163$, the area was monitored by an archaeologist during excavation for possible buried cultural properties.

N. A. Cadoret monitored the borrowing activities on February 13 through March 6, 1989. The borrowing was accomplished with belly loaders. The belly loaders removed dirt in swathes about $3 \mathrm{~m}$ wide by about 0.3 to $1.0 \mathrm{~m}$ deep. After each pass the newly exposed dirt was examined for cultural remains. One feature, a charcoal stained area, was observed. The feature was irregularly shaped, approximately $75 \mathrm{~cm}$ in diameter, basin shaped in profile, and approximately $16 \mathrm{~cm}$ deep. Four $\mathrm{cm}$ of ash at the surface was underlain by charcoal-blackened sand. The woods in the charcoal were bitterbrush and sage. No artifacts or stones were associated with the feature. The feature may have represented an historic firepit or the remnant of a natural burn. One possible FCR was found near the western edge of the borrow area. No other cultural remains were observed during the monitoring. 


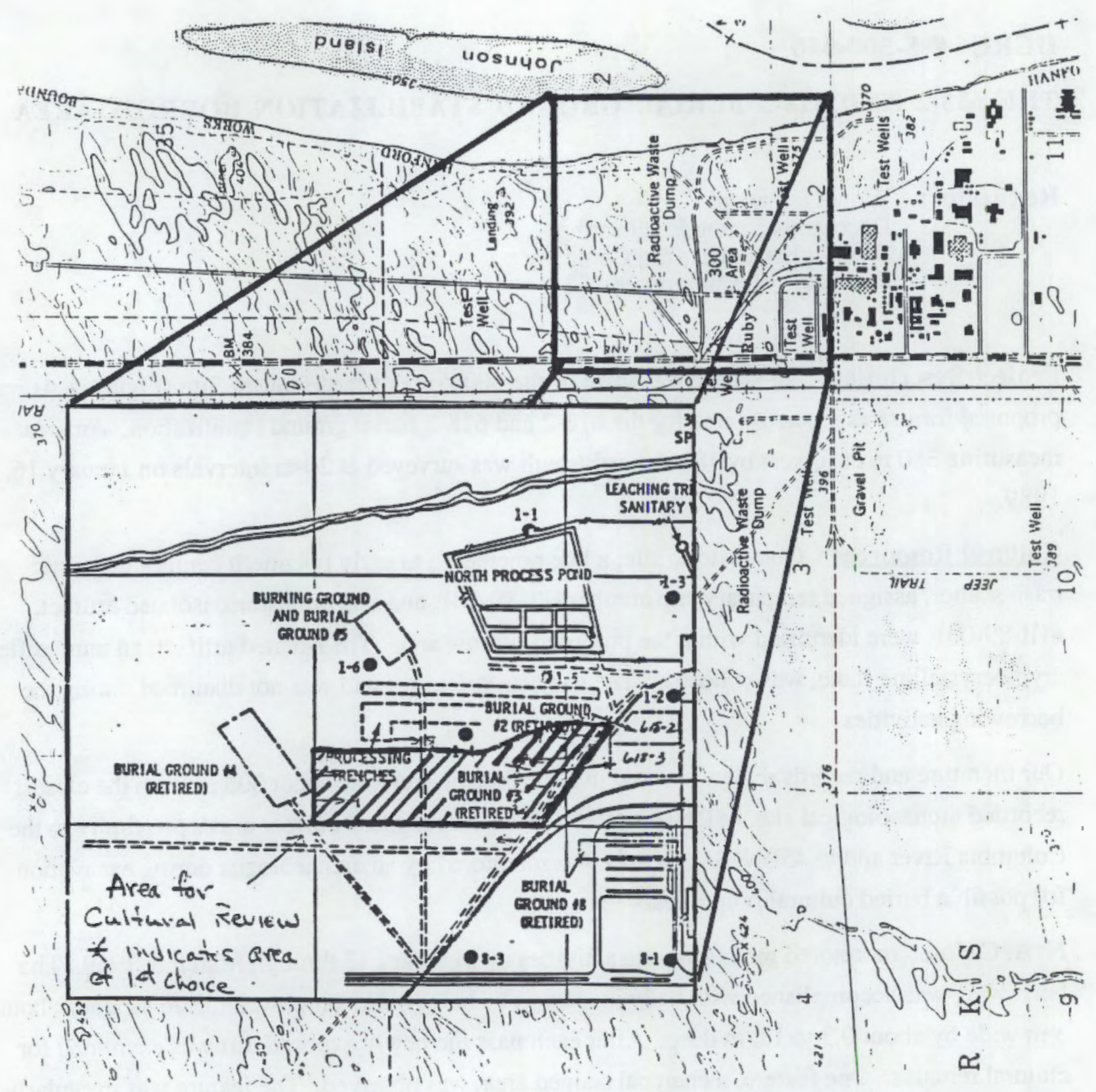

FIGURE A.4. Location of the 618-2 and 618-3 Burial Ground Stabilization Borrow Area, HCRC \#88-300-040, on a Portion of the USGS Richland and Wooded Island Quadrangles, T 10 and $11 \mathrm{~N}, \mathrm{R} 28 \mathrm{E}$ (scale is $1: 24,000$, 1978 editions) 
HCRC \#88-600-001

\title{
THE BARRIER DEVELOPMENT PROGRAM FINE SOIL BORROW PIT AT MCGEE RANCH
}

\author{
Requester: N. R. Wing, T7-25 \\ Geotechnical Engineering Unit \\ Waste Management Systems Engineering \\ Westinghouse Hanford Company \\ Richland, Washington 99352
}

Project Descrintion: Staff of the HCRL conducted a cultural resources review of the proposed fine soil borrow pit at McGee Ranch (see Figure A.5). Most of the proposed borrow area is within old fields. During the survey of the proposed borrow pit conducted between June 7, 1988, and May 4, 1989, a number of historic cultural remains were observed. These include several irrigation systems, old fence lines and roads, farm implements, trash scatters, and ordnance. The historic and recent remains represent several occupations of the site, late nineteenth to early twentieth century through the 1970 s.

No prehistoric remains were identified within the perimeters of the old fields; however, prehistoric artifacts were identified in the surrounding area at some distance from any of the plowed fields. These appeared to represent a surficial deposit. It is, therefore, unlikely that undetected undisturbed prehistoric remains exist in the plowed fields.

We do not, at this point, consider the historic remains to be eligible for inclusion in the National Register because of lack of integrity and the abundance of such remains throughout eastern Washington (e.g., Chatters, J. C. 1980. The Cultural Resources of the Columbia Basin Project. University of Washington, Office of Public Archaeology, Reconnaissance Report 32, Seattle, Washington). It is possible, although unlikely, that the Washington State Historic Preservation Officer will argue otherwise. If he fails to concur with our assessment, the worst case would require us to mitigate impacts to the irrigation features, which would entail careful description and collection of samples of wooden irrigation lines.

Because dense cheatgrass cover made it impossible to obtain a thorough look at the surface of old fields, we would like to monitor for possible buried prehistoric and historic materials when the surface is being exposed. Because the sediments being borrowed are Touchet beds, which often contain large mammal fossils, we will periodically monitor the excavation pits as borrowing progresses. 


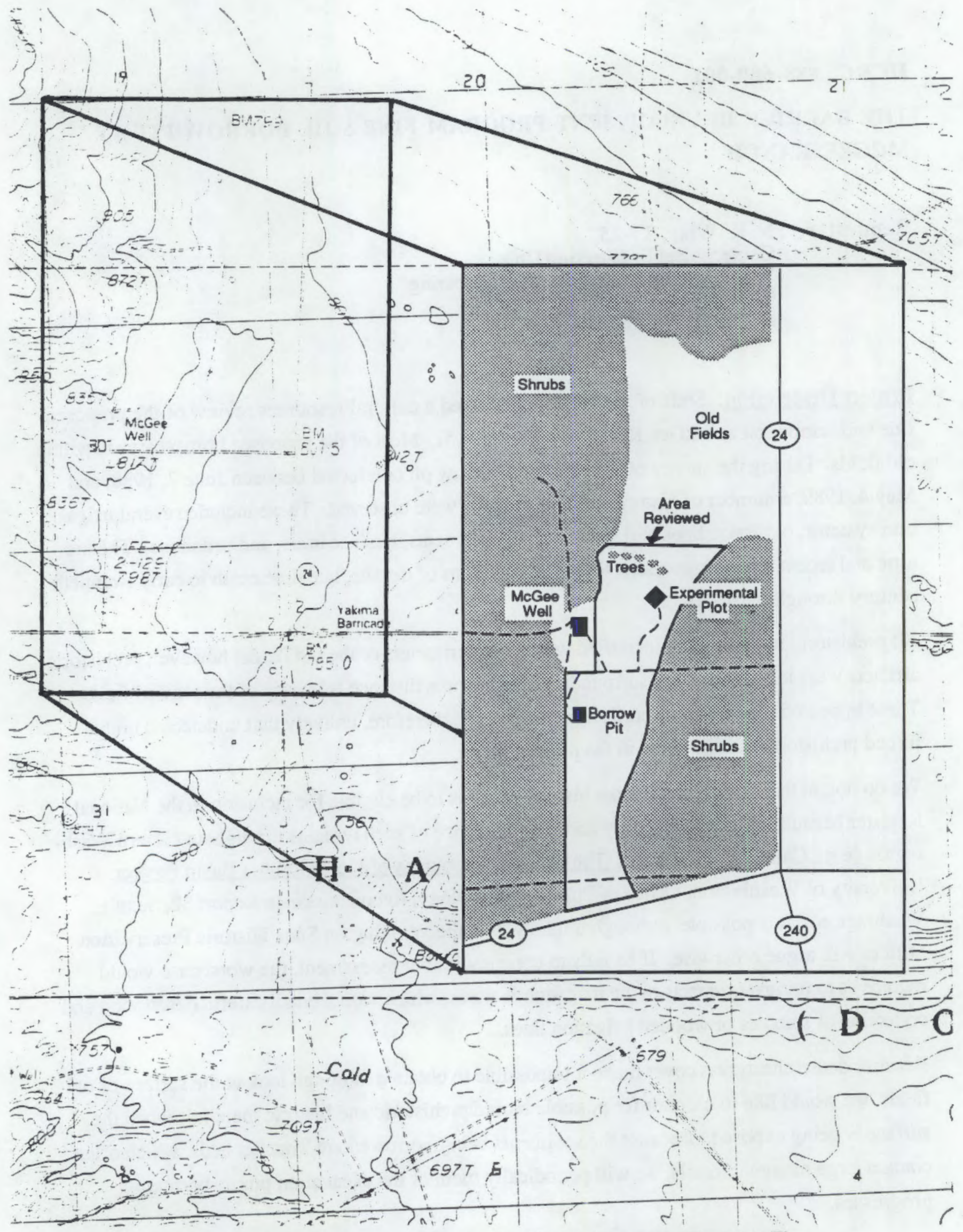

FIGURE A.5. Location of Area Reviewed for the Barrier Development Program Fine Soil Borrow Pit at McGee Ranch, HCRC \#88-600-001, on a Portion of the USGS Riverland Quadrangle, T 13 N, R $25 \mathrm{E}$ (scale is 1:24,000 1986 Provisional Edition) 


\title{
HCRC \#89-600-001
}

\section{CULTURAL RESOURCES REVIEW OF THE FMCS EXTENSION TO ALE}

\author{
Requester: D. R. Brawn \\ Pacific Northwest Laboratory \\ Richland, Washington 99352
}

Project Description: The Facilities Management Control System (FMCS) extension on the Arid Land Ecology (ALE) Reserve will extend the system to include buildings $6652 \mathrm{~K}, 6652 \mathrm{PH}, 6652 \mathrm{I}$, $6652 \mathrm{~J}$, and $6652 \mathrm{H}$ at the ALE headquarters (see Figure A.6). Conduit runs are needed between the buildings to install the necessary signal cable. The approximately $122 \mathrm{~m}$ of trenches will be between 20 and $30 \mathrm{~cm}$ wide. Maximum depth of excavation will be $46 \mathrm{~cm}$.

Our literature and records review showed that no cultural properties are known to be located onsite or in the vicinity. P. E. Minthorn and N. A. Cadoret visited the project site on July 12, 1989. The ground between buildings $6652-\mathrm{PH}$ and $6652-\mathrm{H}$ is a gravelled parking area. The ground between buildings $6652-\mathrm{PH}$ and $6652-\mathrm{K}$ is also largely disturbed. Imported cobbles cover part of the surface. Russian thistle, knapweed, and other vegetation forms a thick cover on the disturbed ground. Undisturbed ground to $20 \mathrm{~m}$ to the east of the proposed line was also examined for cultural properties.

Cultural Resources: No cultural resources were observed. 


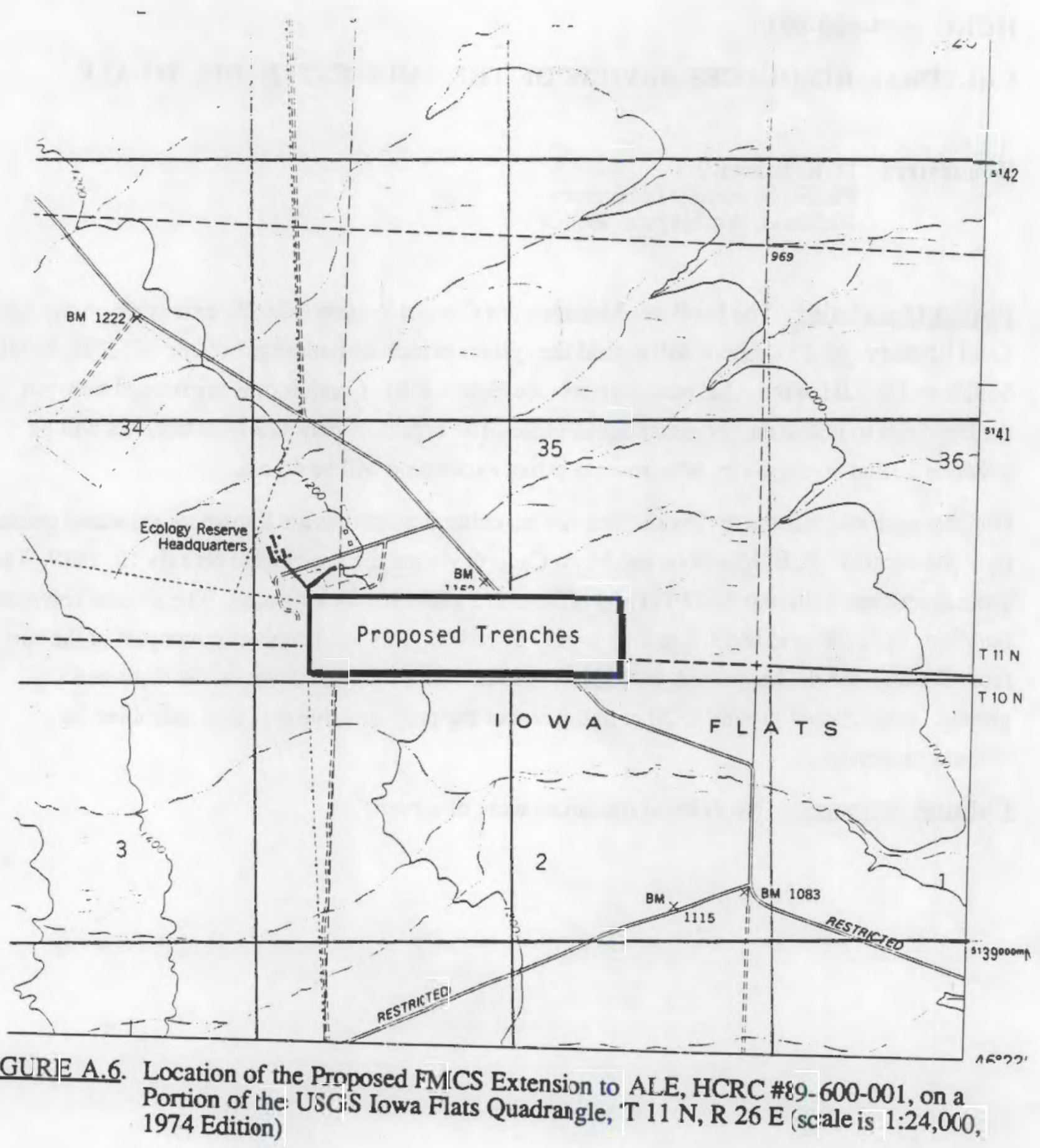


HCRC \#89-600-002

THE HANFORD SOLID WASTE LANDFILL LYSIMETER

\author{
Requester: C. D. Wittreich \\ Regulatory Permitting, Environmental Division \\ Westinghouse Hanford Company \\ Richland, Washington 99352
}

Project Description: Westinghouse Hanford Company plans to install lysimeters at the Hanford Solid Waste Landfill (SWL) in the 600 Area of the Hanford Site (Figure A.7). Several lysimeters will be placed within the fenced SWL, and one background lysimeter will be placed within a $152-\mathrm{m}(500-\mathrm{ft})$ zone outside the fenced SWL. The approximate dimensions of each lysimeter will be $3 \mathrm{~m}$ by $9 \mathrm{~m}$ by a maximum of $9 \mathrm{~m}$ deep.

An intensive pedestrian survey was required in the $152-\mathrm{m}(500-\mathrm{ft})$ zone outside of the SWL as part of the cultural resources review, while a pedestrian survey was not required within the SWL fence. Most of the ground within the SWL fence has been extensively disturbed by previous activities, and that portion of the SWL not extensively disturbed was surveyed by the HCRL in 1987.(a) No cultural resources were identified during that survey. Most of the ground in the $152-\mathrm{m}$ ( $500-\mathrm{ft}$ ) zone is undisturbed.

N. A. Cadoret conducted the pedestrian survey of the $152-\mathrm{m}(500-\mathrm{ft})$ zone on March 28 , March 30 , and April 3, 1989. A total of approximately $0.5 \mathrm{~km}^{2}$ of land was surveyed. The topography is stable to semi-active dunes with areas which contain numerous wind-polished river and flood gravels.

Cultural Resources: Several milk cans and one prehistoric archaeological site (temporary site \# HT-89-002) were identified within the $152-\mathrm{m}(500-\mathrm{ft})$ zone. The site, a sparse lithic concentration, was located in a blowout between low-amplitude dune crests. A variety of colors of cryptocrystalline is represented at the site. Most flakes are bifacial thinning flakes, and most have been broken. Some have been utilized. The site measures about $50 \mathrm{~m}$ north-northeast by $90 \mathrm{~m}$ north-north west. Sediments onsite are poorly sorted, silty, very fine to coarse sand with about a 10-20\%

(a) Letter report dated January 1988 by K. A. Hoover and J. C. Chatters. Cultural Resource Survey of the Solid Waste Landfill Site: Proposed Future Utilization Plots, HCRC \#87-600006. 
pebble/ cobble lag (up to $50 \%$ lag in a few areas). Several boulders are onsite. The closest permanent water appears to be the Columbia River, $10.6 \mathrm{~km}$ to the northeast. No diagnostic artifacts were observed. The construction of the lysimeter within the SWL should not impact this site. 


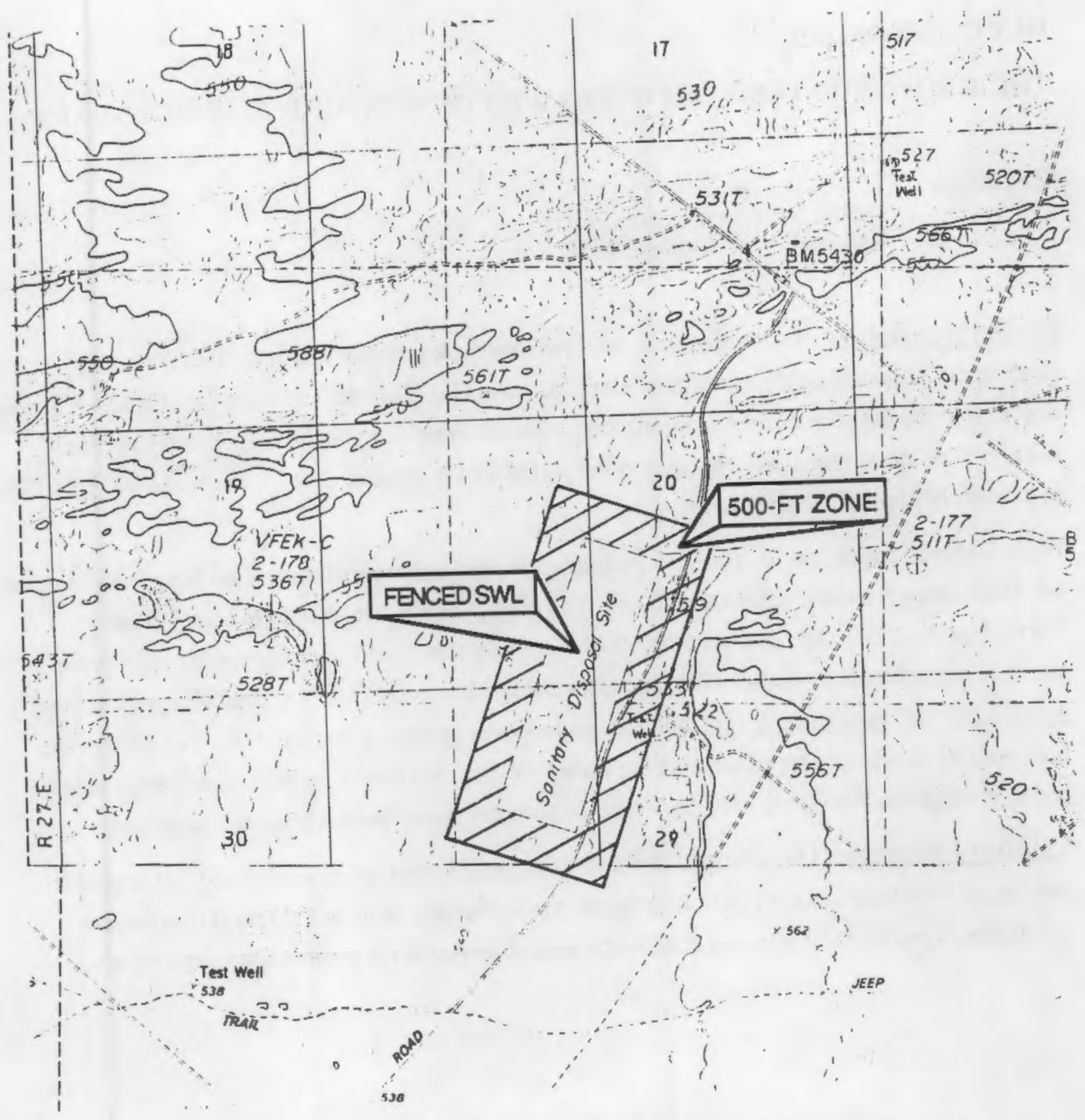

FIGURE A.7. Location of the Hanford Solid Waste Landfill and the 500-ft Zone Surveyed HCRC \#89-600-002, on a Portion of the USGS Horn Rapids Dam and Hanford Quadrangles, T \#12 N, R 27 E (scale is 1:24,000, 1977 Edition and 1986 Provisional Edition) 
HCRC \#89-600-005

\title{
THE GROUNDWATER BOREHOLES AT THE HANFORD SITE BOUNDARY
}

\author{
Requester: T. J. Gilmore \\ Pacific Northwest Laboratory \\ Richland, Washington 99352
}

Project Description: The project will drill two boreholes on the Wahluke State Wildlife Recreation Area, across the Columbia River from the Old Hanford Townsite (see Figure A.8), and one well in the 600 Area of the Hanford Site, adjacent to existing well 42-2. An area approximately $30 \mathrm{~m}$ around the boreholes may be impacted by the project. The $30-\mathrm{cm}$ wells will be drilled to a depth of approximately $152 \mathrm{~m}$.

N. A. Cadoret conducted an intensive pedestrian survey of the project areas on May 9 and August 14,1989 , using a transect interval of $20 \mathrm{~m}$. The project site on the Wahluke State Wildlife Recreation Area is in the northwest corner of a recently tilled field with furrows running north/ south. The ground is essentially flat, and the sediment is mostly silt. Vegetation is predominantly Salsola kali and Bromus tectorum, and the groundcover is approximately $20 \%$. The project site near well 42-2 is in an area of semi-active dunes. Vegetation onsite included Sandberg's bluegrass, cheatgrass, Russian thistle, ragweed, balsamroot, snow buckwheat, and scurf pea.

Cultural Resources: One crimped can and a tangle of barbed wire were noted in the project area on the Wahluke State Wildlife Recreation Area. Neither of these cultural properties are considered significant. A modern coke bottle was observed at the project site near well 42-2. 


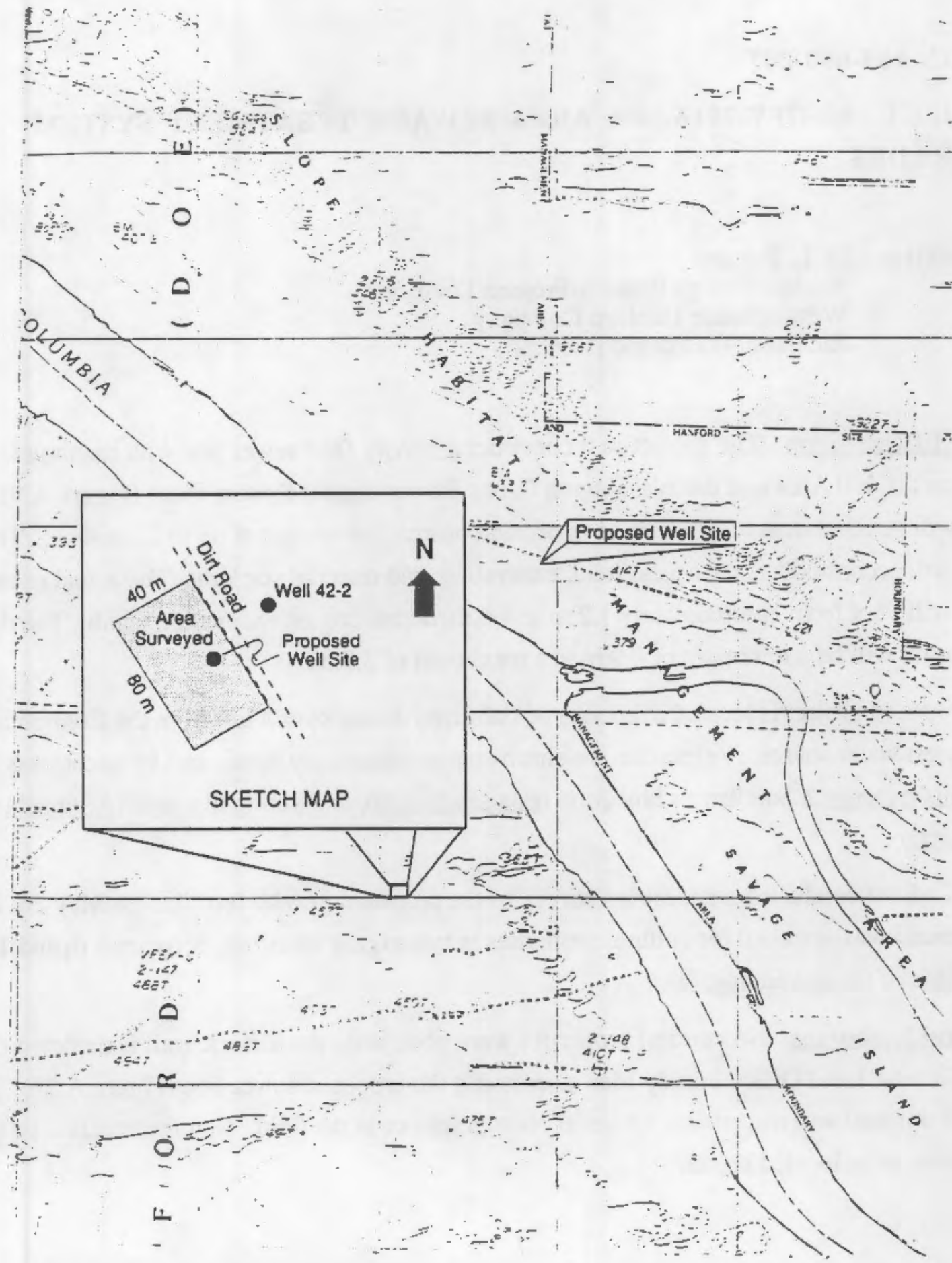

FIGURE A.8. Location of the Proposed Groundwater Well near 42-2, HCRC \#89-600-005, on a Portion of the the USGS Savage Island Quadrangle, T $13 \mathrm{~N}, \mathrm{R} 28 \mathrm{E}$ (scale is $1: 24,000,1986$ Provisional Edition) 
HCRC \#89-600-007

\title{
PROJECT 89L-GFV-791A, 400 AREA SEWAGE TREATMENT SYSTEM UPGRADES
}

\author{
Requester: D. L. Pursley \\ Nuclear Energy Projects/Projects Division \\ Westinghouse Hanford Company \\ Richland, Washington 99352
}

Project Description: The project will construct a gravity feed sewer line with manholes between the 400 Area and the Washington Public Power Supply System Plant (Figure A.9). The route will be $3368 \mathrm{~m}$ in length with an expected construction impact of up to $21 \mathrm{~m}$ wide. This width will accommodate the access road, excavation, and material stacking. The actual excavation width will vary from approximately $1.2 \mathrm{~m}$ to $4.6 \mathrm{~m}$, depending on excavation depth. The depth of excavation will be a minimum of $0.9 \mathrm{~m}$ to a maximum of $3.7 \mathrm{~m}$.

The proposed project is located in an area of stabilized dunes, over $4 \mathrm{~km}$ from the Columbia River, the closest water source. Vegetation is a shrub-steppe community dominated by cheatgrass (Bromus tectorum), Sandberg's bluegrass (Poa sandbergii), and young big sage (Artemisia tridentata).

N. A. Cadoret conducted a pedestrian survey of the proposed gravity feed line on May 26, 1989. The ground was searched for cultural properties in two zigzag transects, between $5 \mathrm{~m}$ and $15 \mathrm{~m}$ on either side of the staked line.

Cultural Resources: No cultural properties were observed. An historic trail is depicted on an 1867 General Land Office Survey Map as crossing the proposed sewer line (Figure A.10). No trace of this trail was discernable on aerial photographs or in the field. No other cultural properties are known to be located onsite. 


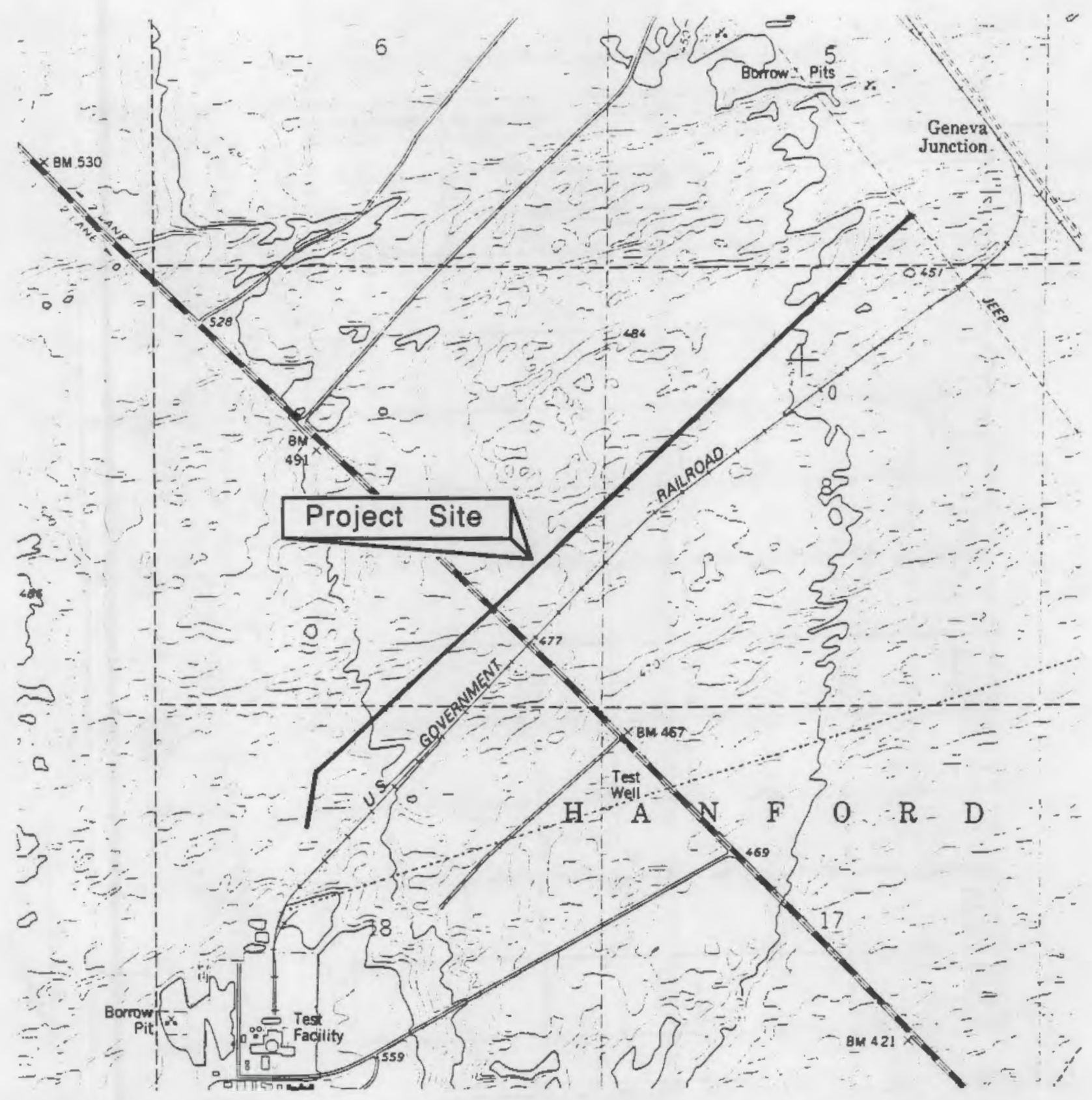

FIGURE A.9. Location of the Proposed 400 Area Sewage Treatment System Upgrades, HCRC \#89-600-007, on a Portion of the USGS Wooded Island Quadrangle, T $11 \mathrm{~N}, \mathrm{R} 28 \mathrm{E}$ (scale is $1: 24,000,1978$ Edition) 


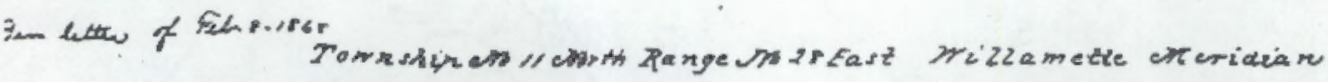

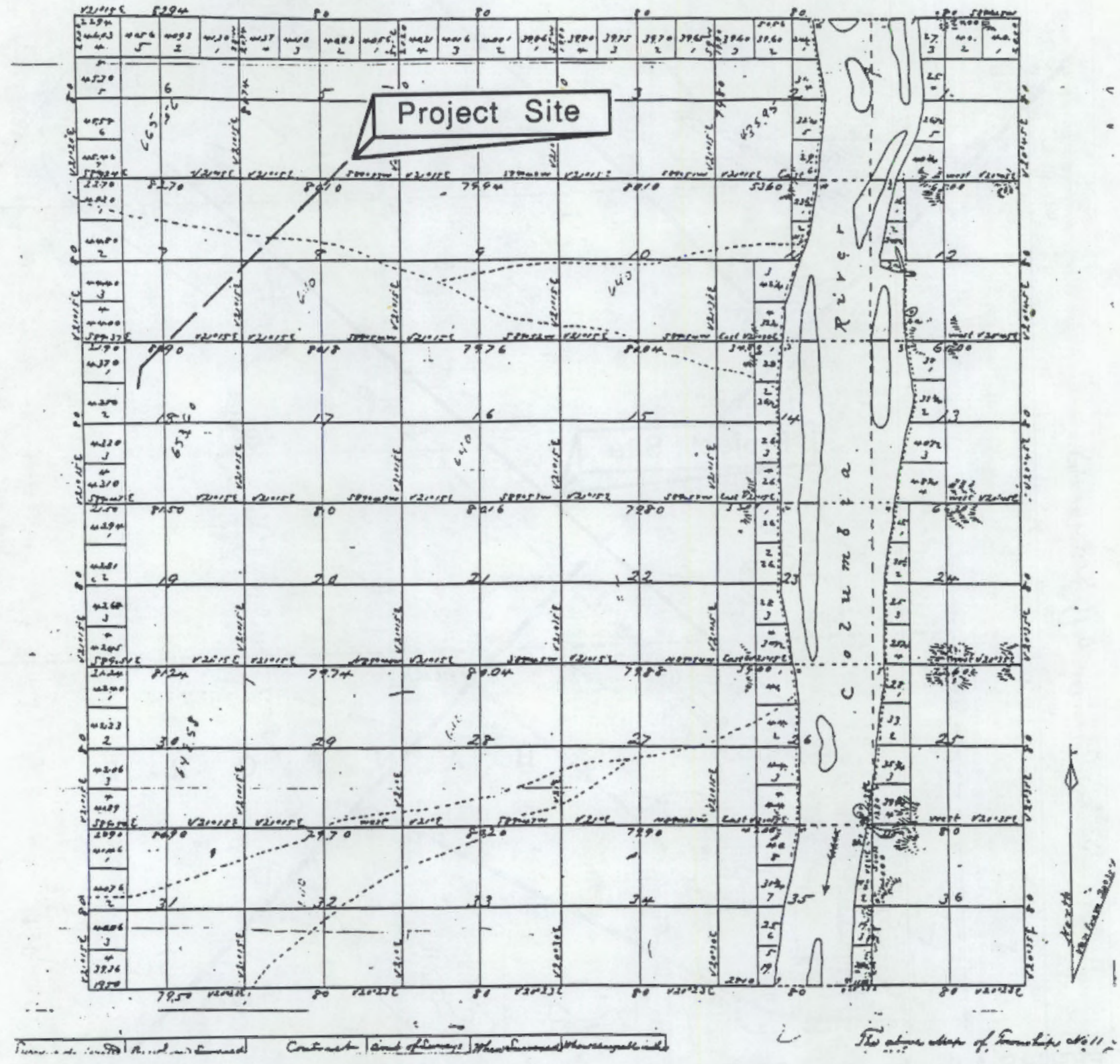

FIGURE A.10. 1867 General Land Office Survey Map and Approximate Location of the Proposed Sewer Line 
HCRC \#89-600-009

\title{
THE FENCED IN SITU VITRIFICATION SITE
}

\author{
Requester: C. L. Timmerman \\ Pacific Northwest Laboratory \\ Richland, Washington 99352
}

Project Description: Pilot and large-scale tests will be performed at the recently fenced In Situ Vitrification Project site in the 600 Area of the Hanford Site (see Figure A.11). Excavations may be to a depth of $12 \mathrm{~m}$.

Our literature and records review show that no cultural properties are known to be located onsite. The project area was examined on August 22, 1989, by P. E. Minthorn. The southern part of the site has been graded and is stabilized with gravel. The northern part of the site and the fenceline was searched at $10-\mathrm{m}$ intervals for cultural properties. Both areas have been disturbed. The northern part of the site has apparently been graded, and the fenceline has been grubbed. Sediments are eolian sands and silt overlying Pleistocene fluvial gravels. The northem part of the area has been partially revegetated with cheatgrass and Russian thistle. The surrounding topography is stabilized dunes.

Cultural Resources: No cultural resources were identified. 


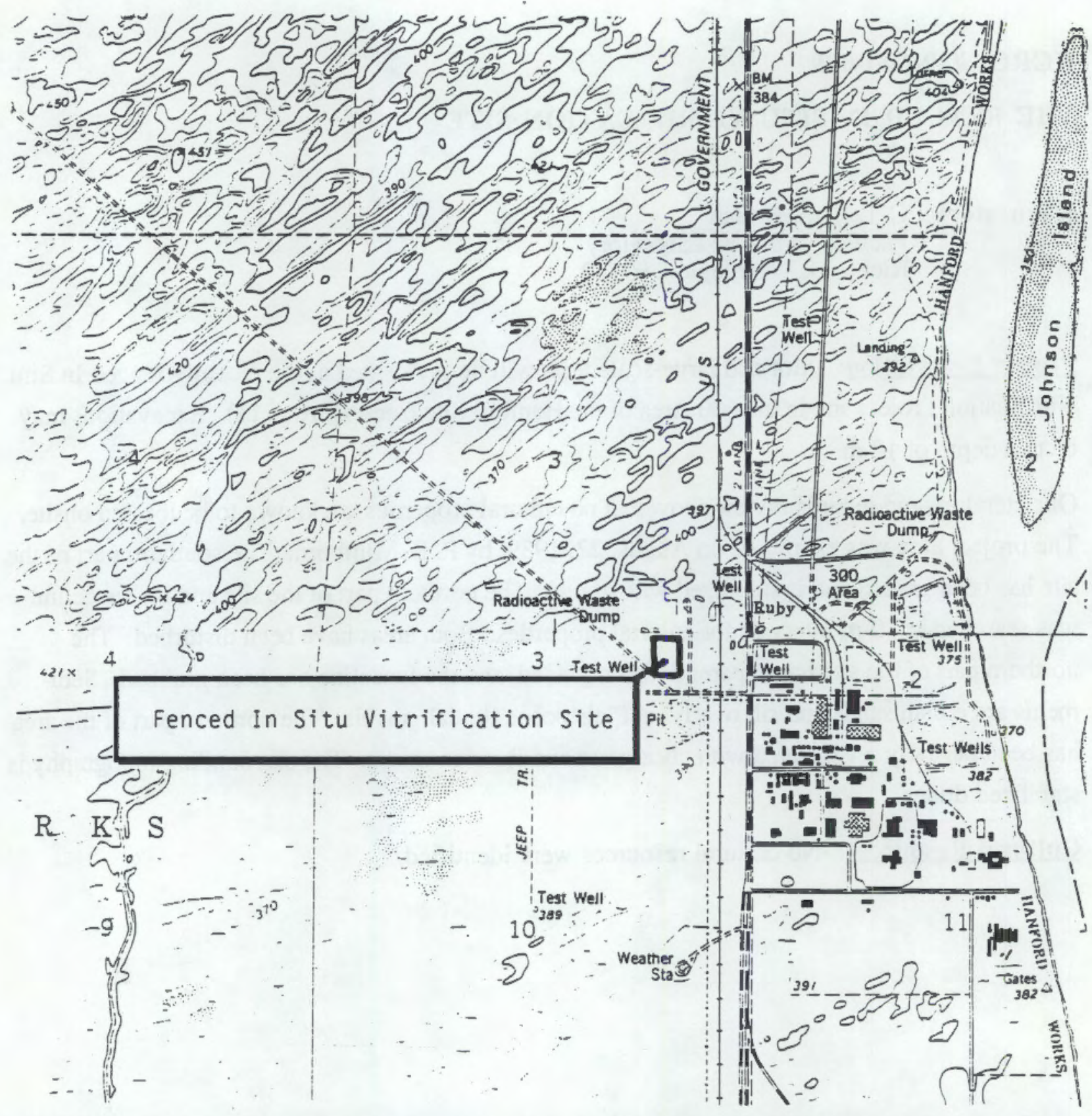

FIGURE A.11. Location of the Fenced In Situ Vitrification Site, HCRC \#89-600-009, on a Portion of the Richland and Wooded Island Quadrangles, T 10 and $11 \mathrm{~N}$, $\mathrm{R} 28 \mathrm{E}$ (scale is $1: 24,000,1978$ Editions) 
HCRC \#88-1100-002

\title{
CULTURAL RESOURCES REVIEW OF THE 1100 AREA FENCE INSTALLATION
}

\author{
Requester: F. J. Muller, R3-43 \\ Defense Waste Management Projects \\ Westinghouse Hanford Company \\ Richland, Washington 99352
}

Project Description: Five potential CERCLA sites were to be fenced in the 1100 and 600 Areas of the Hanford Site (see Figure A.12). These sites are the battery acid pit, the antifreeze pit, the paint and solvent pit, the discolored soil site, and the Horn Rapids landfill. The fence around the battery acid pit was to describe a square measuring $9 \mathrm{~m}$ on a side (Figure A.13), the fence around the antifreeze pit was to describe an irregular hexagon measuring $43 \mathrm{~m}$ by $113 \mathrm{~m}$ by $73 \mathrm{~m}$ by $50 \mathrm{~m}$ by $40 \mathrm{~m}$ by $56 \mathrm{~m}$ (Figure A.14), the fence around the paint and solvent pit was to describe a polygon measuring $116 \mathrm{~m}$ by $76 \mathrm{~m}$ by $81 \mathrm{~m}$ by $38 \mathrm{~m}$, the fence around the discolored soil site was to describe a triangle measuring $99 \mathrm{~m}$ by $84 \mathrm{~m}$ by $49 \mathrm{~m}$ (Figure A.15), and the fence around the Hom Rapids landfill was to describe an irregular hexagon measuring $165 \mathrm{~m}$ by $350.5 \mathrm{~m}$ by $244 \mathrm{~m}$ by $478.5 \mathrm{~m}$ by $283 \mathrm{~m}$ by $165 \mathrm{~m}$ (Figure A.16). Subsequently the project was changed so that warning signs will be put up instead of the chain link fence. The signs will be erected at approximately $30.5-\mathrm{m}$ intervals along the fence lines.

The site of the discolored soil site is located between two abandoned irrigation ditches. These ditches have also been disrupted by roads, railroads, and other developments, and do not appear to meet criteria for inclusion on the National Register. Additionally, the cleanup of this area is a public health concern that overrides any historic value an abandoned ditch may have.

On November 15, 1988, N. A. Cadoret conducted a pedestrian survey of the proposed Horn Rapids landfill fenceline. The corners of the proposed fenced area had been staked. J. C. Chatters surveyed a swath, $40 \mathrm{~m}$ wide, along the proposed fenceline.

Cultural Resources: Our literature and records review show that no cultural properties are known to be located onsite. The proposed locations for all of the signs, except for those around the Horn Rapids landfill and the discolored soil site, are in ground which has been disturbed by previous facilities development in the 1100 Area. A pedestrian survey of the disturbed areas was not warranted. 
One historic site, HT-88-030, an isolated milk can, and a segment of an irrigation canal were identified during the survey. The site, located in the swale between stabilized dune crests, is a concentration of domestic trash. Artifacts include a cocoa tin, a lard tin, other food cans, two complete bottles, a Fletcher's Castoria bottle, and a bottle embossed "WHITEMORE BOSTON USA 5 FLUID OZ.," a Kerr jar embossed "KERR GLASS CO PATENTED AUG 311915 SAND SPRINGS OKLA," and porcelain bowl fragments with a floral design. The site measures about $7.5 \mathrm{~m}$ in diameter, and most artifacts were partially buried. The site probably does not meet criteria for inclusion on the National Register. 


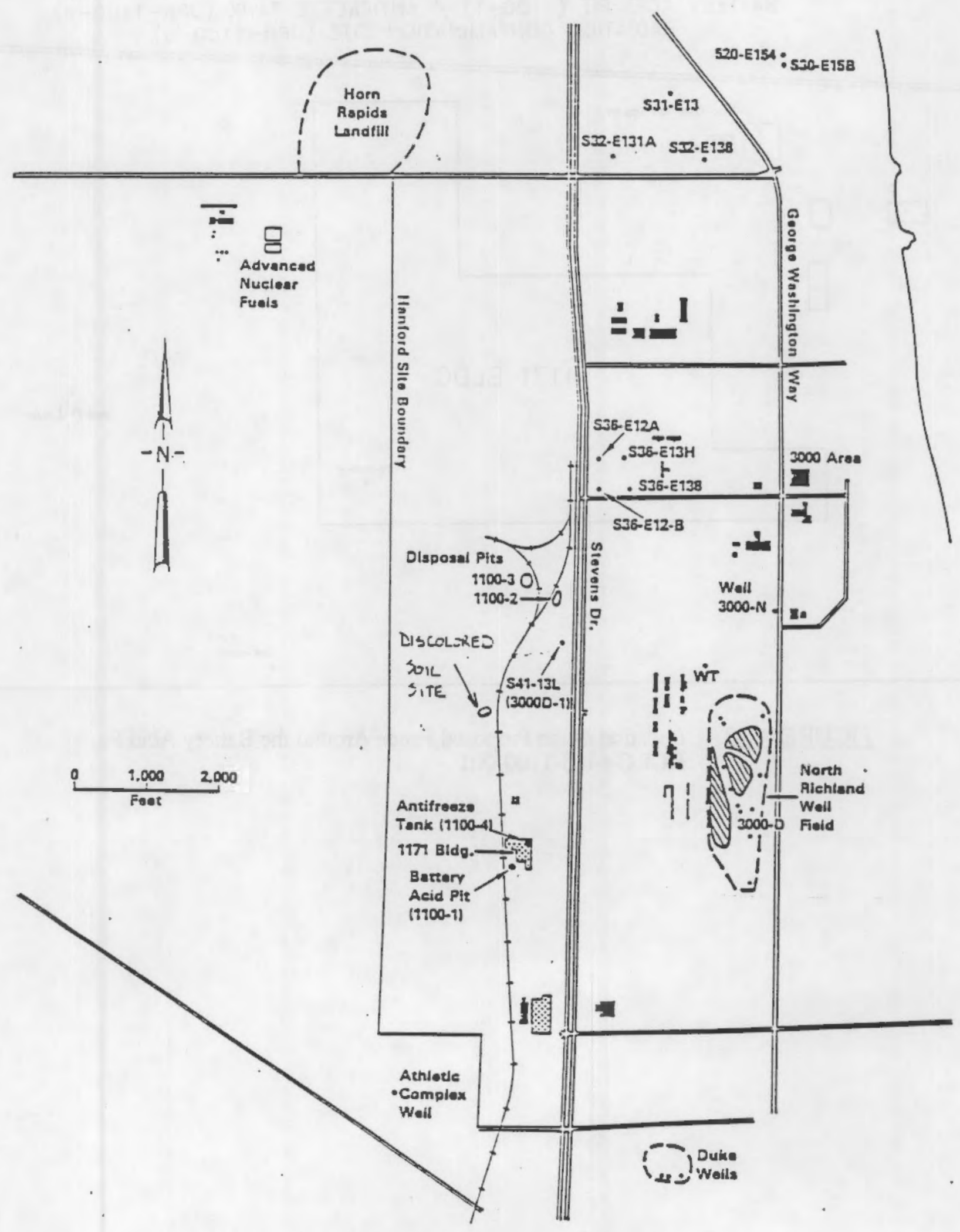

FIGURE A.12. Location of Potential CERCLA Sites, HCRC \#88-1100-002 


\section{BATTERY ACID PIT $(1100-1)$ / ANTIFREEZE TANK (UPR-1100-4)}

RADIATION CONTAMINATION SITE (UPR-1100-5)

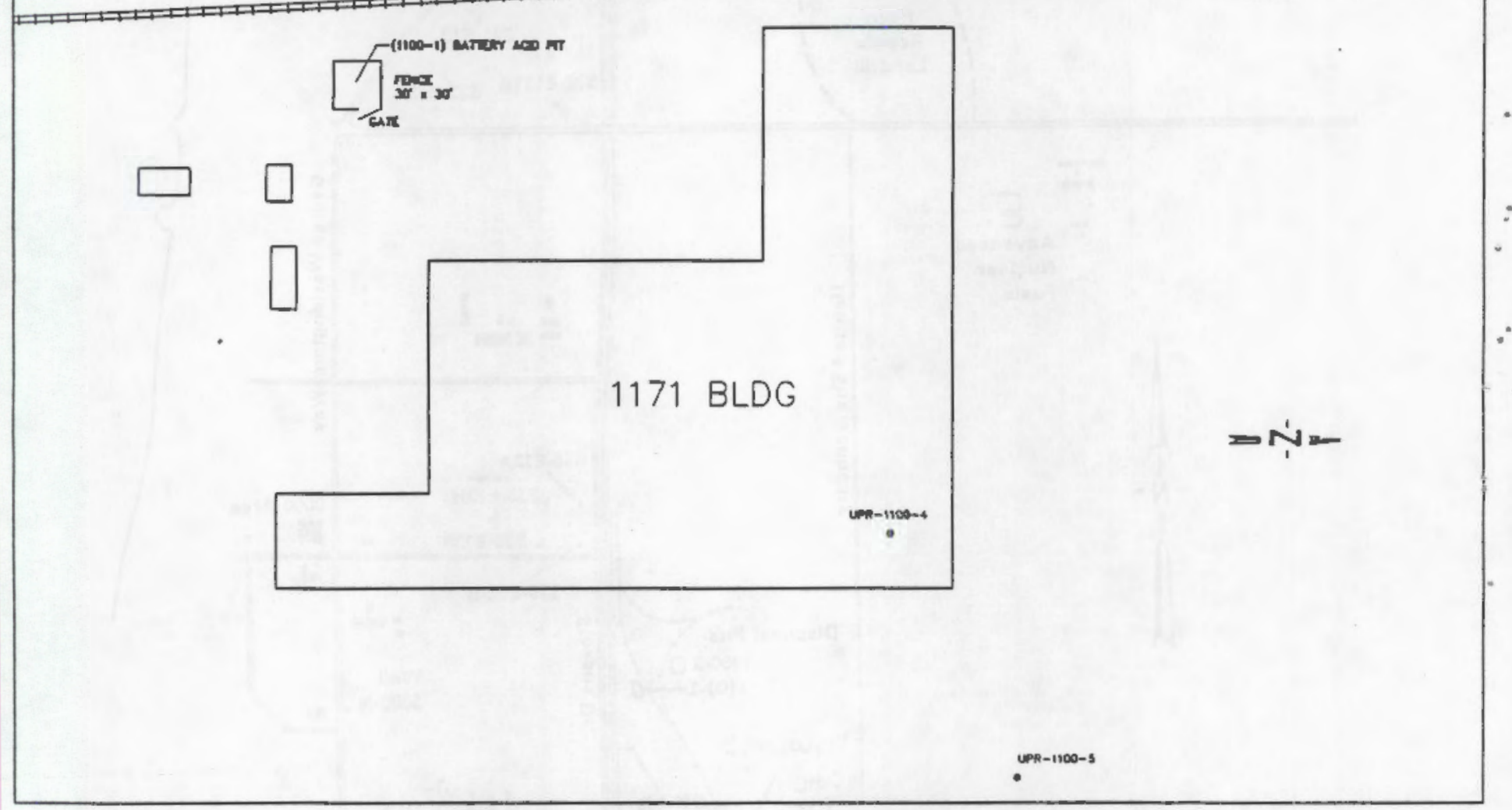

FIGURE A.13. Location of the Proposed Fence Around the Battery Acid Pit, HCRC \#488-1100-001 


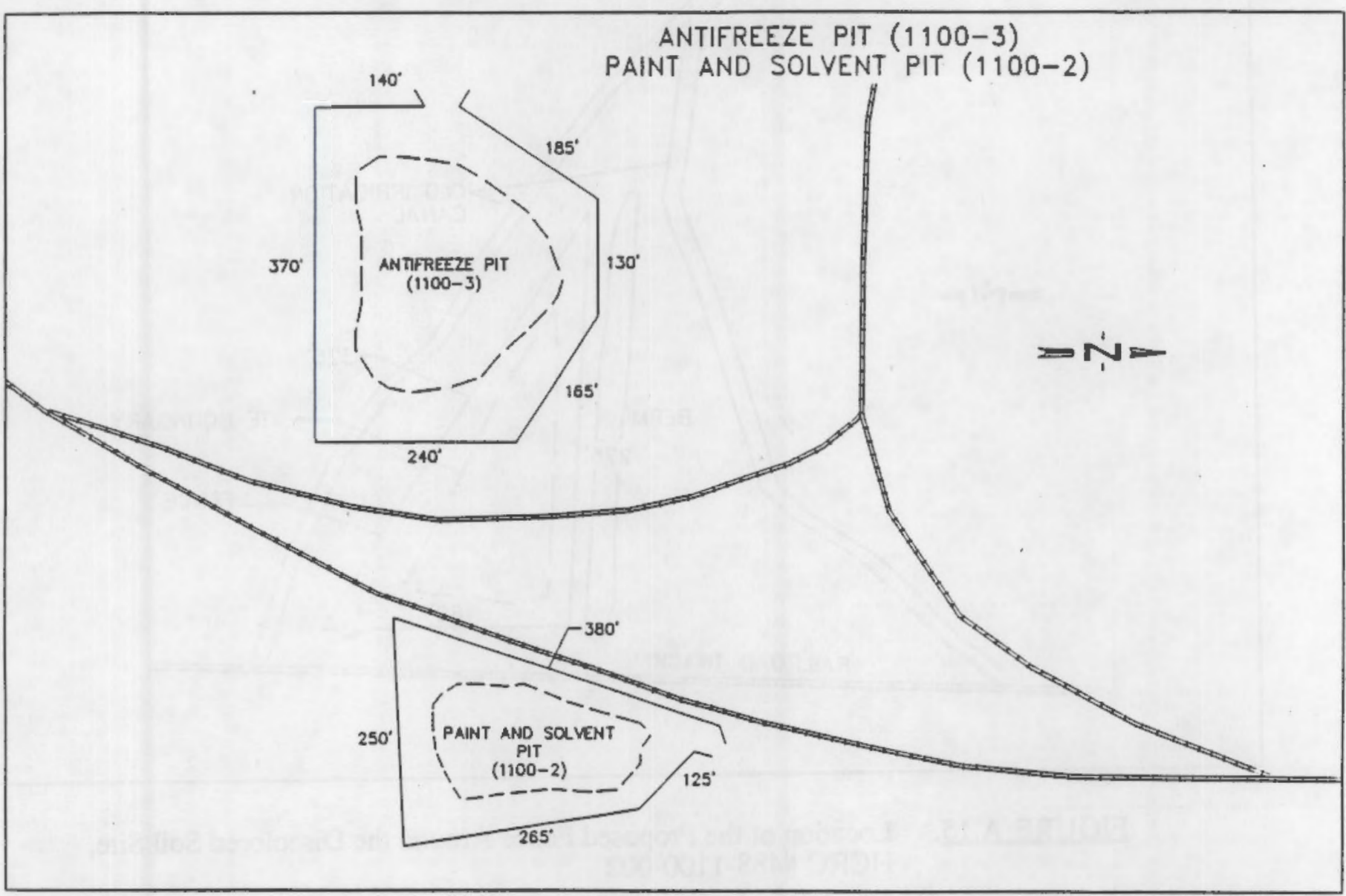

FIGURE A.14. Location of the Proposed Fences Around the Antifreeze and Paint and Solvent Pits, HCRC \#88-1100-001 


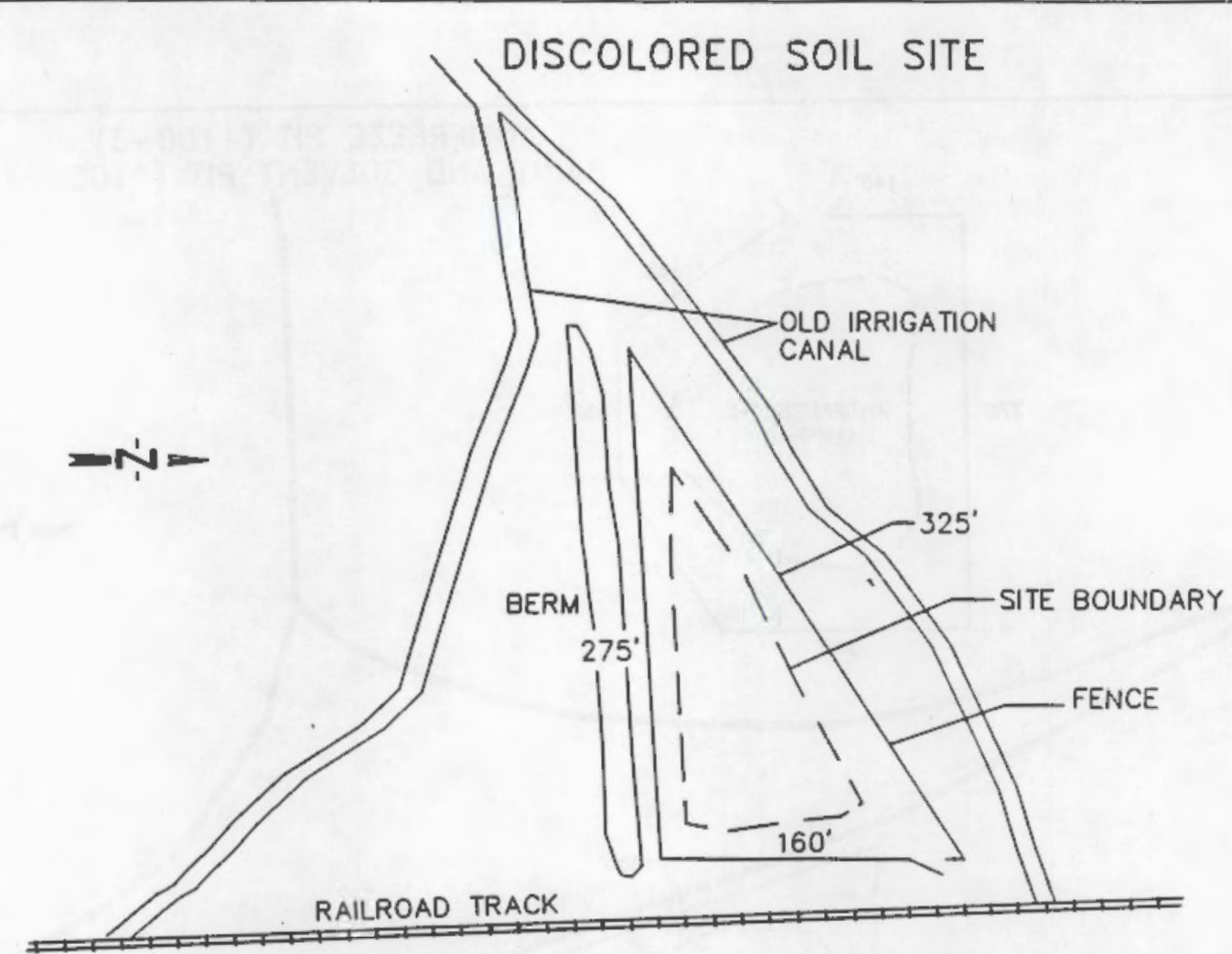

FIGURE A.15. Location of the Proposed Fence Around the Discolored Soil Site, HCRC \#488-1100-002 


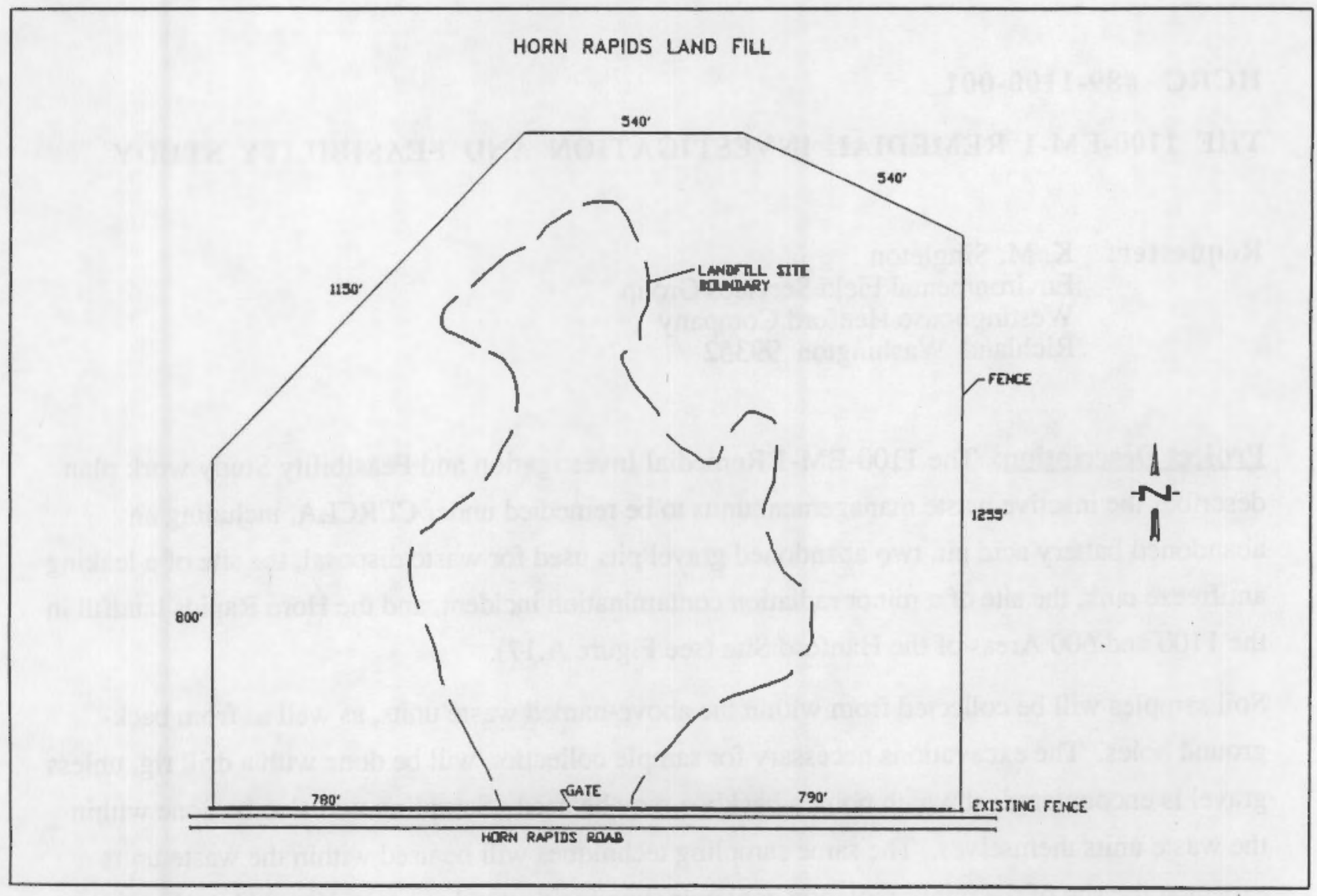

FIGURE A.16. Location of the Proposed Fences Around the Horn Rapids Landfill, HCRC \#88-1100-002 
HCRC \#89-1100-001

THE 1100-EM-1 REMEDIAL INVESTIGATION AND FEASIBILITY STUDY

\author{
Requester: K. M. Singleton \\ Environmental Field Services Group \\ Westinghouse Hanford Company \\ Richland, Washington 99352
}

Project Descrintion: The 1100-EM-1 Remedial Investigation and Feasibility Study work plan describes the inactive waste management units to be remedied under CERCLA, including an abandoned battery acid pit, two abandoned gravel pits used for waste disposal, the site of a leaking antifreeze tank, the site of a minor radiation contamination incident, and the Horn Rapids landfill in the 1100 and 600 Areas of the Hanford Site (see Figure A.17).

Soil samples will be collected from within the above-named waste units, as well as from background holes. The excavations necessary for sample collection will be done with a drill rig, unless gravel is encountered, at which point a backhoe may be used. Sampling will also be done within the waste units themselves. The same sampling techniques will be used within the waste units except at the site of the minor radiation contamination incident, where samples will be taken by hand.

On a site tour conducted by K. M. Singleton and S. Skvarek on April 4, 1989, three areas were identified in proximity to the disposal areas where background samples will be taken. Each area was marked by a wooden lath. S. Skvarek requested that an area $61 \mathrm{~m}$ around each stake be reviewed.

Our literature and records review showed that no cultural properties are known to be located onsite. The ground at all of the waste units, except the site of the minor radiation contamination incident, has been disturbed by previous use of the facilities. Therefore, a pedestrian survey of these areas was not warranted. Because of safety concerns, the site of the minor radiation contamination incident was also not surveyed, but viewed from a distance. The three areas designated for background sampling have not been disturbed previously, and thus, a pedestrian survey of these areas was necessary as part of our review.

On April 5 and 6, 1989, N. A. Cadoret conducted an intensive pedestrian survey of the three areas to be used for background sampling. An area measuring approximately $61 \mathrm{~m}$ around each stake was searched for cultural properties, using a transect interval of $20 \mathrm{~m}$. 
Cultural Resources: No historic properties were identified in the areas to the west of the battery acid pit and to the west of the Horn Rapids landfill. In the area to the west of the antifreeze pit, the trace of an old road, and an abandoned irrigation ditch were identified. Portions of the irrigation ditch have been disrupted by roads and the antifreeze pit (see Figure A.18). These features do not appear to meet criteria for inclusion on the National Register of Historic Places.

The site of the minor radiation contamination incident is located between two abandoned irrigation ditches (Figure A.19). These ditches have also been disrupted by roads, railroads, and other developments, and do not appear to meet criteria for inclusion on the National Register. Additionally, the cleanup of this area is a public health concern that overrides any historic value an abandoned ditch may have. 


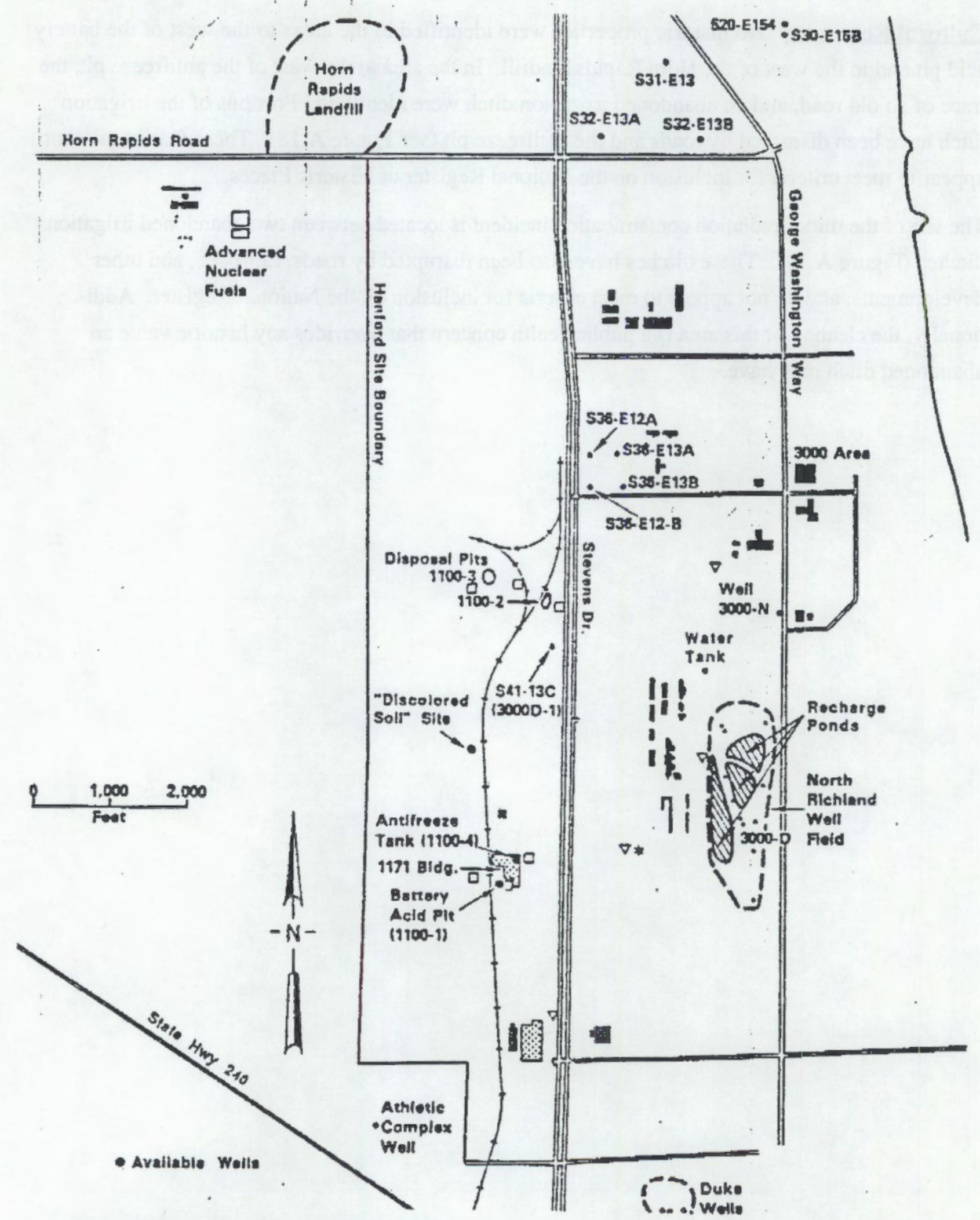

FIGURE A.17. Waste Site Locations for the 1100-EM-1 Operable Unit and Proposed Locations of Background Samples, HCRC \#89-1100-001 

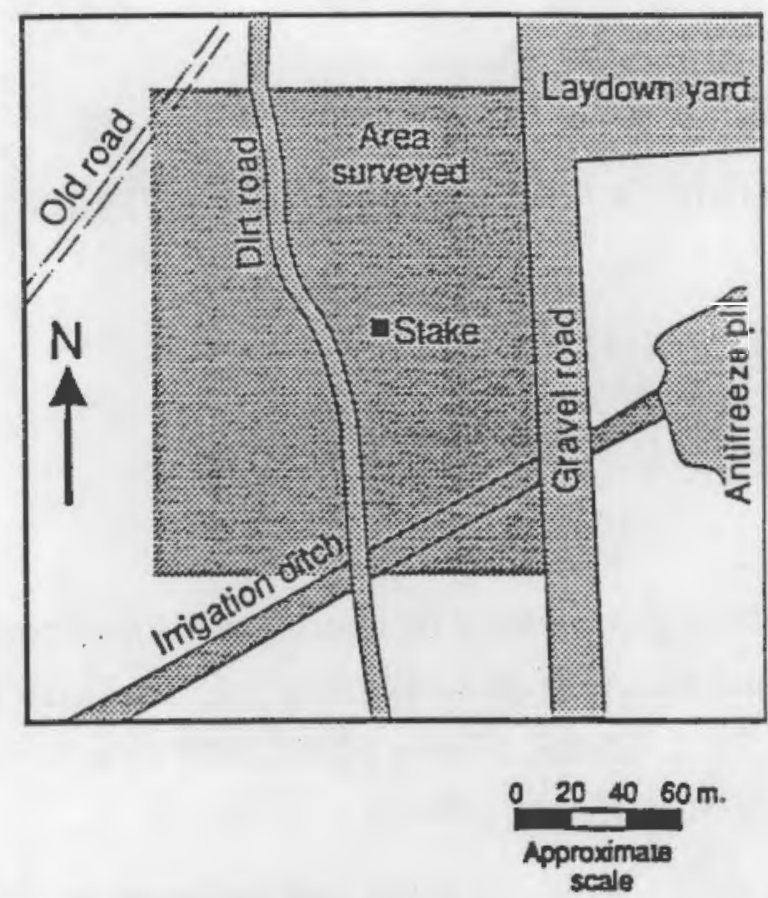

FIGURE A.18. Sketch Map of the Proposed Background Sample Area to the West of the Antifreeze Pit, and Cultural Properties Identified, HCRC \#89-1100-001

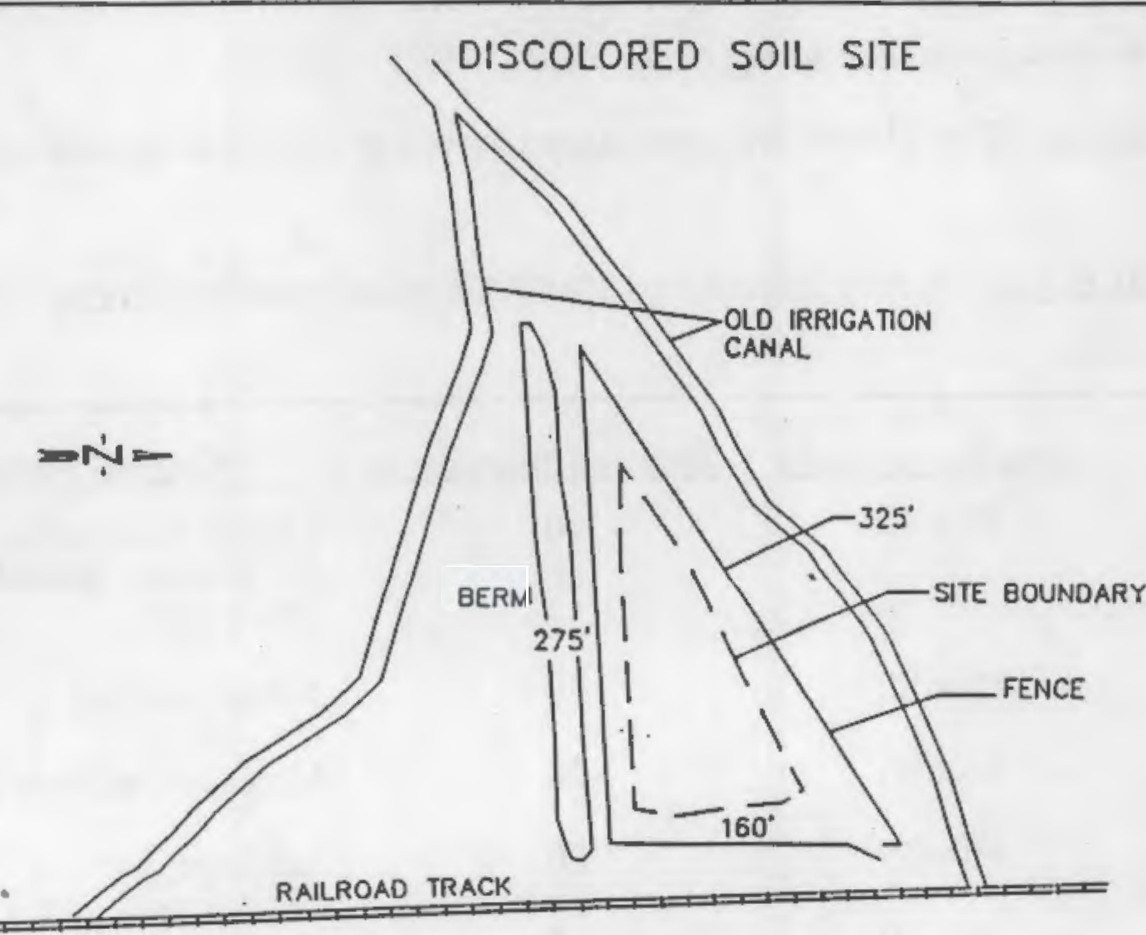

FIGURE A.19. Sketch Map of the Site of the Minor Radiation Contamination Incident (discolored soil site), HCRC \#89-1100-001 
HCRC \#89-1100-002

THE CERCLA GROUNDWATER MONITORING WELLS

Requester: C. E. Hodge, R3-43

Defense Waste Management

Westinghouse Hanford Company

Richland, WA, 99352

Project Description: Fifteen groundwater monitoring wells near possible CERCLA sites need to be drilled in the 1100 and 600 Areas of the Hanford Site (see Figures A.20 through A.22).

These wells are MW-1, MW-2, MW-3, MW-4, MW-5, MW-6, MW-7, MW-8, MW-10, MW-11, MW-12, MW-13, MW-15, MW-16, and MW-17.

Our literature and records review show that no cultural properties are known to be located at the proposed well sites. MW-2, MW-3, MW-4, and MW-5 are in ground that has been previously disturbed by road or facilities construction. N. A. Cadoret visited the remaining proposed well sites located in mostly undisturbed ground on July 10 and August 2, 1989. MW-1 and MW-17 are located within an area previously surveyed for HCRC \#89-1100-001.

Cultural Resources: The table below summarizes survey strategy and cultural materials observed.

TABLE A.2. Survey Results for CERCLA Groundwater Monitoring Wells

\begin{tabular}{|c|c|c|c|}
\hline Well Location & Area Surveyed, $m$ & Transect Intervals. m & Cultural Materials \\
\hline MW-10 & $40 \times 40$ & 10 & $\begin{array}{l}\text { Cobble feature } \sim 23 \mathrm{~m} \text { long } \mathrm{x} \\
1.5 \mathrm{~m} \text { wide, probably from field } \\
\text { clearing }\end{array}$ \\
\hline MW-6 & $80 \times 80$ & 20 & None observed \\
\hline MW-7 & $80 \times 80$ & 20 & Milk can and three crimped cans \\
\hline MW-8, 16 & $40 \times 35$ & 20 & Lard can \\
\hline MW-11 & $30 \times 30$ & 7.5 & None observed \\
\hline MW-12, 13 & $40 \times 40$ & 10 & Barbed wire \\
\hline MW-15 & $30 \times 30$ & 7.5 & None observed \\
\hline
\end{tabular}


None of the cultural materials observed are considered significant. We did, however, suggest that MW- 10 be moved so as not to disturb the cobble feature. John Lindberg has agreed to move the well approximately $40 \mathrm{~m}$ to the northeast (Telcon $8 / 25 / 89$ ). 


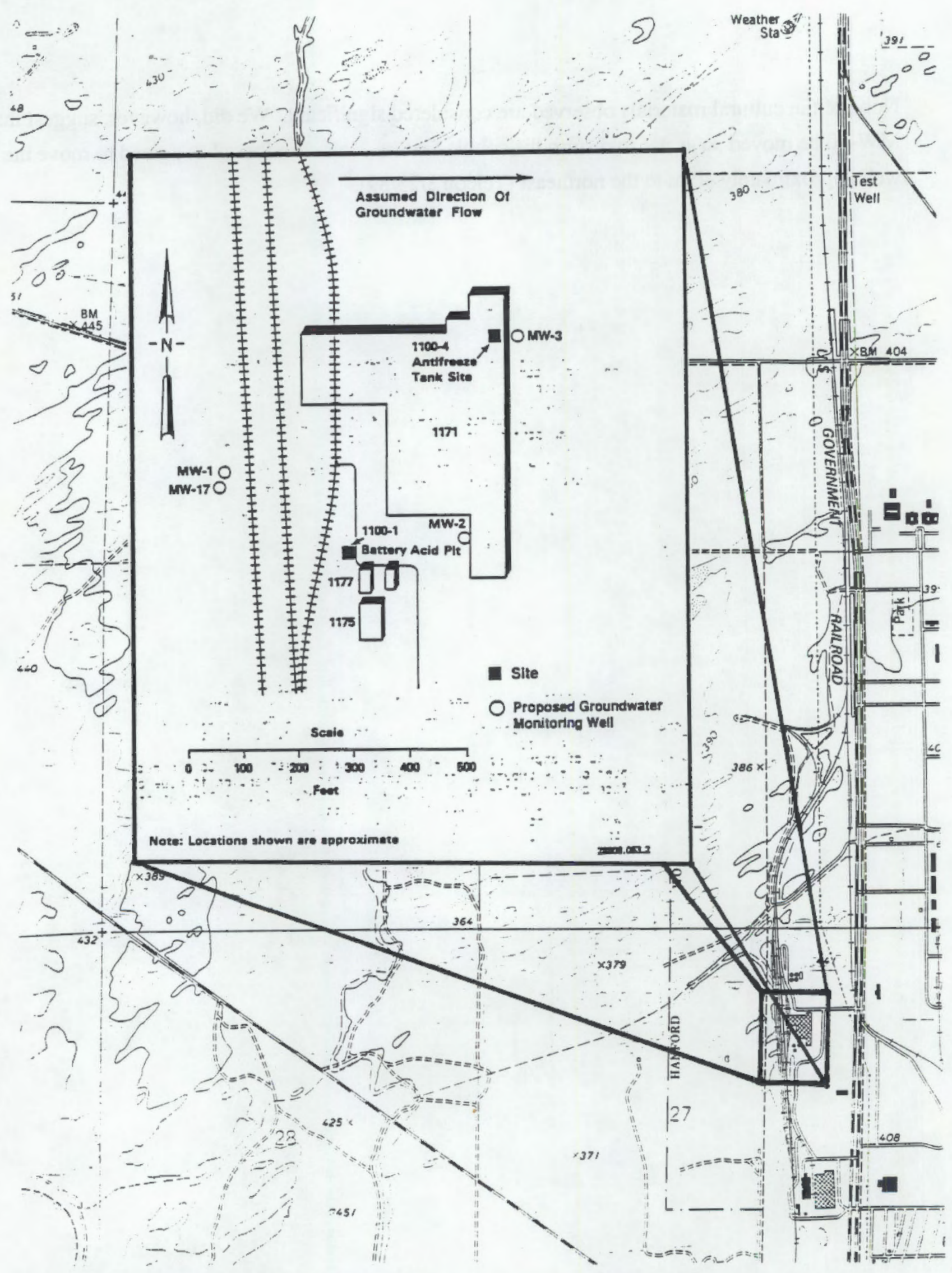

FIGURE A.20. Location of MW-1, MW-2, MW-3, and MW-17, HCRC \#89-1100-002, on a Portion of the USGS Richland Quadrangle, T $10 \mathrm{~N}, \mathrm{R} 28 \mathrm{E}$ (scale is $1: 24,000,1978$ Edition) 


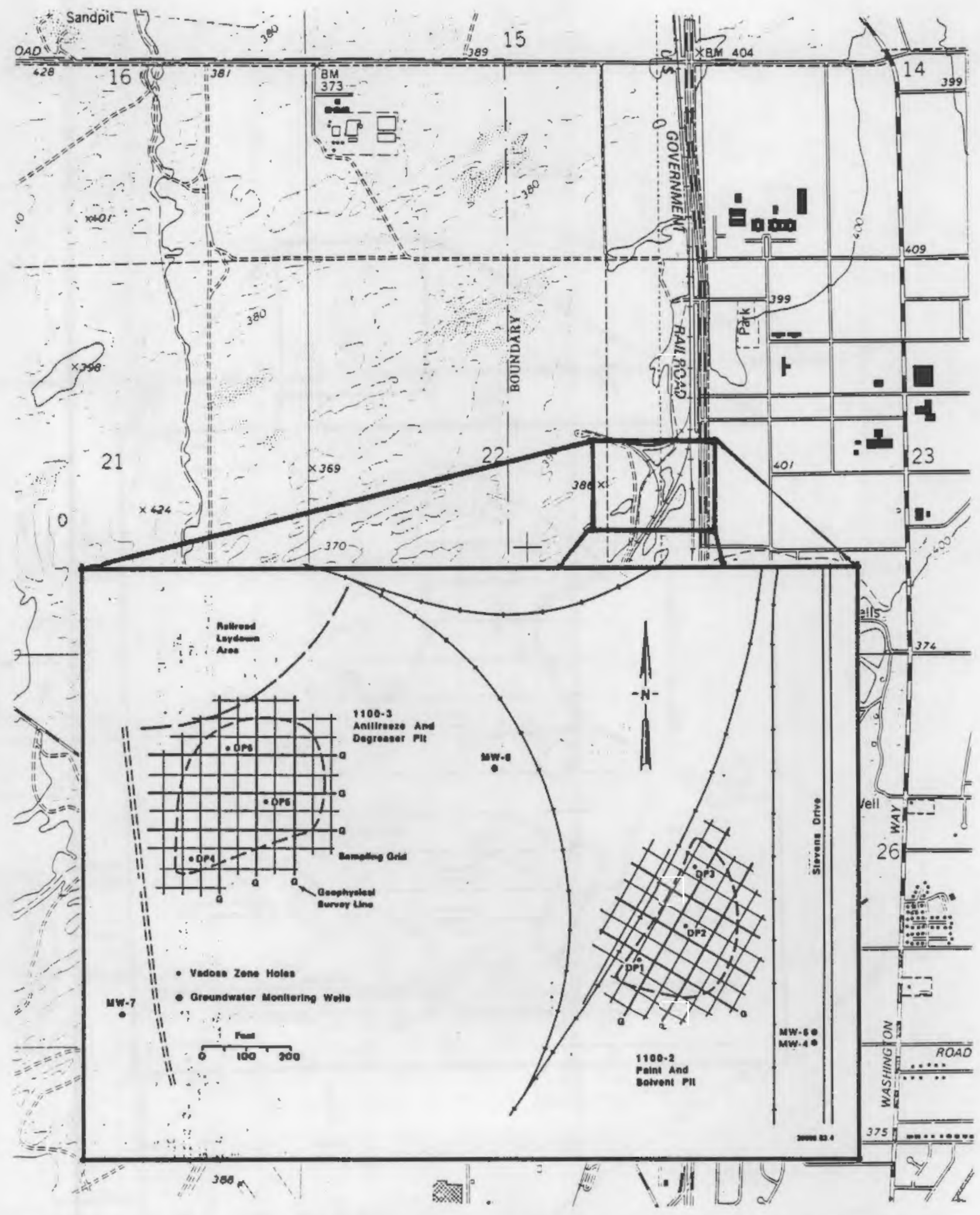

FIGURE A.21. Location of MW-4, MW-5, MW-6, and MW-7, HCRC \#89-1100-002, on a Portion of the USGS Richland Quadrangle, T $10 \mathrm{~N}, \mathrm{R} 28 \mathrm{E}$ (scale is $1: 24,000,1978$ Edition) 


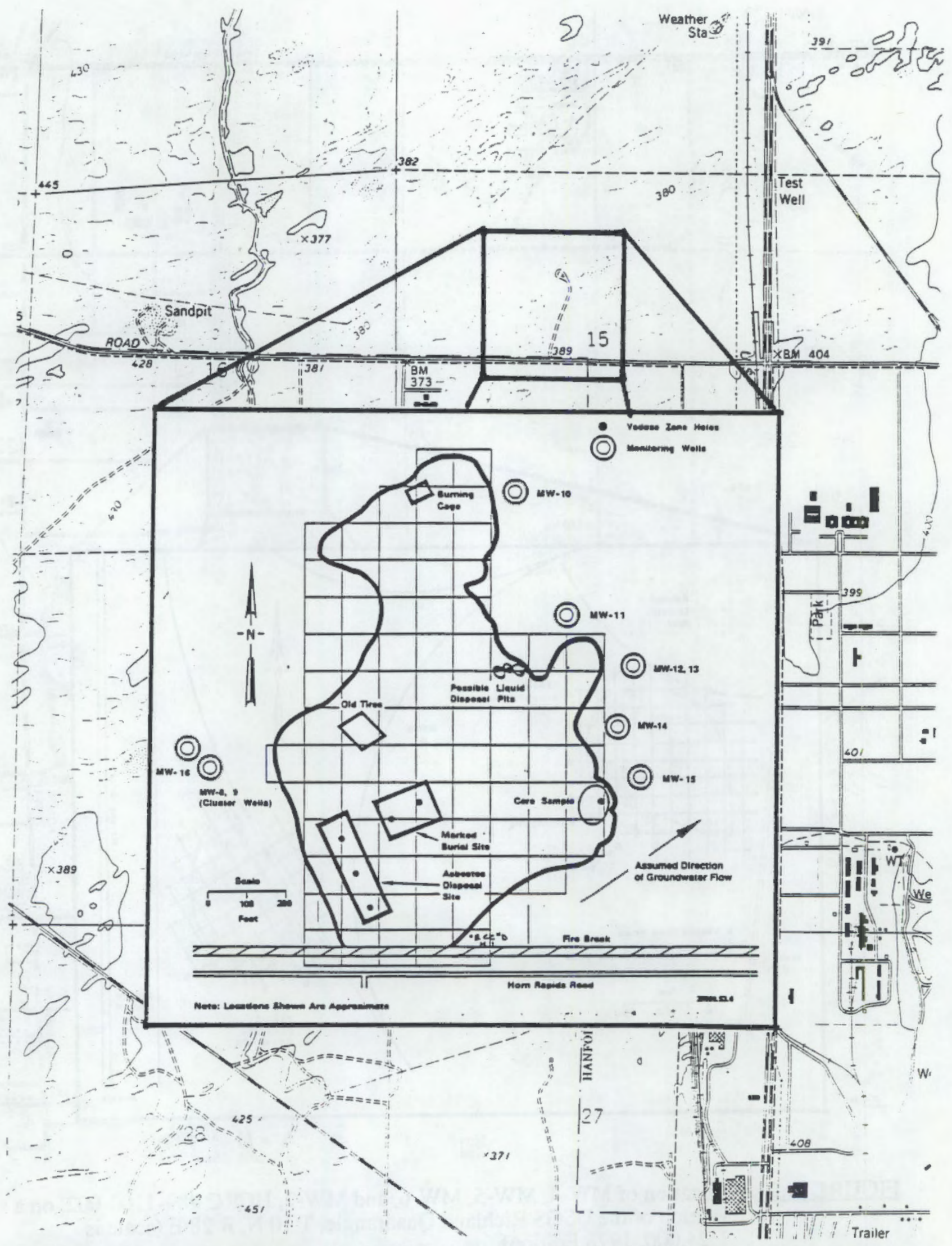

FIGURE A.22. Location of MW-8, MW-10, MW-11, MW-12, MW-13, MW-15, and MW-16, HCRC \#89-1100-002, on a Portion of the USGS Richland Quadrangle, T 10 $\mathrm{N}, \mathrm{R} 28 \mathrm{E}$ (scale is $1: 24,000,1978$ Edition) 


\author{
APPENDIX B \\ CULTURAL RESOURCES MONITORING \\ OBSERVATIONS FOR THE FY 1989 MONITORING CYCLE
}




\section{APPENDIX B}

\section{CULTURAL RESOURCES MONITORING OBSERVATIONS FOR THE FY 1989 MONITORING CYCLE}

\section{B.1 CEMETERIES}

45BN124. This site is described by Rice (1968) as an historic Wanapum burial site located in a dune approximately $150 \mathrm{~m}$ from the Columbia River bank. The dune area is approximately 90 by $60 \mathrm{~m}$, and human bones were observed weathering from the dune by Rice's survey staff. HCRL staff members were able to find the dune, which is largely stabilized, and confirm its location and dimensions, but found no evidence of bone.

No anthropogenic disturbance of the site was evident. Erosion was normal for a stabilized dune setting.

45BN128. This cemetery is located on a large island close to the Columbia River's western bank. It is described by Rice (1968) as an historic Wanapum burial site in a dune measuring approximately 150 by $120 \mathrm{~m}$ and containing an unknown number of graves. Artifacts representative of the late prehistoric and historic periods were reported along with human bones. When inspected in 1989, the dune was still active, and two large blowouts were present. The larger blowout and a ridge adjacent to it were littered with fragments of human bone, both charred and uncharred. Large stones were also present in small numbers. Two beads, one of shell and another of black glass were found, along with the tip of a serrated projectile point similar to the Rabbit Island Stemmed style. There is no evidence of recent disturbance, although the rusted blade of a shovel lay among the fragments of human bone.

There were no human remains in the second blowout, but a shell midden occurred, consisting of both Margaritifera and Gonidea species and measuring approximately $4 \mathrm{~m}$ long by $0.2 \mathrm{~m}$ thick. Scattered around the shell midden, with dimensions of 10 by $25 \mathrm{~m}$, were cobble cores, firecracked rock (FCR), basalt flakes, anvil stones and a few cryptocrystalline flakes. Where it had not yet weathered from the dune, this deposit was $1.5 \mathrm{~m}$ below the dune surface. This component has characteristics common to sites of the Cascade Phase.

Unless there is surface collecting activity, of which no traces were seen, this site receives no impacts except natural erosion at this time. 
45BN139. This site is in a dune that dominates the center of the next large, high-water island above 45BN128. Rice states that the site contains an unknown number of unmarked Wanapum burials and measures approximately 150 by $90 \mathrm{~m}$. No artifacts or human remains were observed; the site was identified by Wanapum elders.

During the 1989 inspection, we found that the site had been marked slightly out of position on maps in Rice (1968). There, it is shown as located in the center of the island, where an old orchard stands. The dune is actually upstream of the mapped location, measures approximately 120 by $200 \mathrm{~m}$, and includes site 45BN140. Most of the dune surface is stabilized, but there is one large blowout near its upper end [designated 45BN140, a campsite, by Rice (1968)], in which we found the deflated remains of at least six graves. Five circular concentrations of stones measuring 3 by $5 \mathrm{~m}$ in diameter occur in association with fragmentary human bones in an area measuring 30 by $60 \mathrm{~m}$. It is highly probable that many additional graves occur in stabilized portions of these dunes marked by cairns.

No disturbance of the site is evident other than wind erosion. Tracks of wheeled vehicles on other areas of the island indicate that Hanford workers visit the area, and surface collection may be a problem. No direct evidence of such activity was apparent, however.

45BN151. Section 106 reviews have been conducted at this site over the past 2 years in conjunction with decontamination activities. The site, identified by Wanapurn elders, is described as being located in an area of low stabilized dunes and boulder fields northwest of the $\mathrm{K}$ trench. It is $450 \mathrm{~m}$ long and $150 \mathrm{~m}$ wide. No artifacts or human remains have been found there by previous archaeological teams. Two sets of markers, one consisting of signs and the other of concrete posts, purport to designate the site boundaries, although they do not coincide with each other or with Rice's (1968) map. We assume that the entire stabilized dune area encompasses the cemetery.

HCRL staff found no grave markers, fragments of bone, or artifacts (other than two cryptocrystalline flakes) on the surface, which is largely covered by various grass species. There is no evidence of recent anthropogenic disturbance.

45BN157b. This site is located in a large dune deposit on Jaeger Island. It lies outside the security area of the Hanford Site and has been subject to looting at least since the 1930s. The site measures approximately $100 \mathrm{~m}$ by $300 \mathrm{~m}$ and contains artifact deposits that are at least $2 \mathrm{~m}$ deep. FCR, animal bone, shell fragments, and cobble tools pave the surface of deflated areas, and artifacts make up the majority of stones found along the beach. Cryptocrystalline flakes are uncharacteristically rare for a site that appears to have a major late prehistoric component (Rice 1980). The site is a traditional Wanapum cemetery and is known to have had many human remains and 
grave goods removed from it in the past. In 1987, a complete skeleton was uncovered by a member of the Benton County Sheriff's department and subsequently reburied by the Wanapum.

Given this history, it is not surprising that the site continues to be visited by relic collectors. It is commonly visited for other reasons as well. The nearby Jaeger homestead is a popular camping area, and fishermen put in their boats along the island's shoreline. HCRL staff have made numerous visits to the site, and each time observe footprints in the blowouts and small pits dug into shell features that are still weathering from the site matrix.

45BN306c (45GR306a, 306b). This site appears to be a case of mistaken identity. During his research along the Columbia River in the 1920s, Herbert Krieger of the Smithsonian Institute conducted excavations into a cemetery at the Wahluke (Krieger 1928). According to his report, he excavated in a cemetery located in dunes upstream of a housepit village. Archaeological site records, however, identify the site as being in a dune parallel with and west of the village. Human bones are reported as weathering from the dune.

Students and faculty from Central Washington University, along with HCRL staff members, mapped the Wahluke site, conducted test excavations, and inspected the cemetery area reported by Rice (1968). Despite the presence of blowouts that composed over $30 \%$ of the dune area, no bone fragments or evidence of grave cairns were found. However, numerous concentrations of large stones resembling collapsed caims occur on dunes upstream of the village site (45GR306b), both in the southern end of that site and in the adjacent 45BN306a. This site, rather than the reported 45BN306c, appears to constitute the cemetery.

The site is on DOE land managed by the U.S. Fish and Wildlife Service, and public access is prohibited. There is no evidence for recent disturbance on the cemetery area as described above. However, remnants of camp fires on the site attest to the fact that members of the public make unauthorized visits. Its presence beside a popular salmon and sturgeon fishing hole make the site vulnerable to such visits.

\section{B. 2 SITES LISTED ON THE NATIONAL REGISTER OF HISTORIC PLACES}

\section{B.2.1 Savage Island Archaeological District}

45BN118. This site is described by Rice as consisting of between 18 and 24 housepits and associated FCR extending $120 \mathrm{~m}$ by $45 \mathrm{~m}$ along the Columbia River bank, opposite Savage Island. Cobble tools and hopper mortar bases are said to be present. 
HCRL staff were able to locate the site, but found that it lacked any evidence of house pits. It consists instead of a $170-\mathrm{m}$ by $65-\mathrm{m}$ scatter of mussel shell fragments in early to mid-Holocene alluvium. FCR, a very few flakes of cryptocrystalline and basalt, anvil stones and bits of fish and mammal bone also occur. The river bank exposure and four large (12- to 16-m diameter), apparently erosional pits have exposed the shell layers, which extend from approximately 1 to over $2 \mathrm{~m}$ below the surface. The site is coterminus with a shoreline spring, and at least 10 depressions have been dug into river cobbles at and below the high water mark, apparently for access to fresh water. The site appears to be quite old, perhaps dating to the early Frenchman Springs or Cascade Phase, or both.

There is no evidence of recent disturbance to the site, which now has a dense cover of cheatgrass.

45BN119. Rice (1968) describes this site as an open camp $105 \mathrm{~m}$ long and $45 \mathrm{~m}$ wide, consisting of FCR concentrations and having been severely eroded by wind and water. Cobble tools, leafshaped and contracting-stemmed projectile points have been found there.

We found the site to be approximately $400 \mathrm{~m}$ long with a width of up to $100 \mathrm{~m}$, and approximately the southern two-thirds of the site has been removed during borrowing operations. Close inspection of air photographs in Rice (1968) revealed that this borrowing had already occurred at the time the site was described. Stratigraphically, the site consists of early Holocene alluvial fine sand overlain by a layer of Mazama volcanic ash up to $50 \mathrm{~cm}$ thick and covered by eolian sand of varying thickness. The cultural deposit occurs at the contact between eolian sand and Mazama ash and is intermixed with both strata. Artifacts consist of mussel shell, bone, FCR cobble cores, anvil stones, hopper mortar bases, cobble spalls, hammer stones, and a few projectile point fragments and flakes of various materials. These facts plus the description of projectile points found in the 1968 survey place this site in the late Cascade Phase (7000 - 4500 B.P.).

There is no evidence of recent land disturbance at this site, but a ridge of undisturbed site matrix that crosses the borrow pit is being eroded by wind. Recent vehicle tracks to the site do indicate, however, that the site may be subject to surface collection.

45FR258. This site is located in the southern portion of Savage Island and is reported to measure approximately 150 by $300 \mathrm{~m}$. It contains artifacts common to the Cayuse Phase (last $2000 \mathrm{yr}$ ) and has been extensively damaged by relic hunters. Burials were reported as having come from this site (Rice 1968).

HCRL staff visited this site only briefly and found that it fit the description provided by Rice. In fact, the looting alluded to in the 1968 report is still going on. Numerous pits of varying 
ages were evident. The site is also being subjected to severe stock damage. The entire southern tip of the site is a mass of hoofprints and is devoid of vegetation. This accelerates erosion, and the exposed artifacts attract relic collectors. In addition to these forms of disturbance, at least one hunting blind had been dug into the site.

45FR260. This site is reported as a small campsite ( 30 by $90 \mathrm{~m}$ ) along the northwestern edge of Savage Island. It is said to contain FCR, cobble tools, notched sinkers, and projectile points of the Cayuse Phase.

In 1989 , the site was found to extend another $100 \mathrm{~m}$ to the northwest, but otherwise to fit the description given. In addition, mussel shell, bone fragments, and milling stones were observed.

The site is subject to wind erosion exacerbated by stock damage. Although there is a possibility that relic hunters have looted the site in the past, no evidence of recent digging was observed. However, it is possible that the milling of stock in this area, which is ongoing, has obliterated recent looter pits.

45FR262. Rice (1968) calls this an open camp, 60 by $150 \mathrm{~m}$ in extent, consisting of scattered concentrations of FCR and cobble tools, notched net sinkers, a knife, and a hopper mortar base. HCRL staff found his observations to be accurate for the present as well. The site is on a riverlevel gravel bar, and has probably been entirely deflated.

No evidence of erosion or relic collector activity was seen. Vegetation obscures much of the site surface and probably discourages surface collection.

\section{B.2.2 Hanford North Archaeological District}

45BN125. This site is described as an open campsite containing " several housepits ... and a number of caim burials," extending over $1200 \mathrm{~m}$ along the river bank upstream of the Hanford Townsite (Rice 1968, page 7). The silted-in housepits are reportedly on the lower terrace of the site, while the caim burials are on the upper terrace along a track road.

HCRL staff found the site dimensions to be $560 \mathrm{~m}$ by as much as $30 \mathrm{~m}$, but did not find either housepits or cairns. Artifacts are densely scattered in roads, wind hollows, or rodent burrows in a narrow body of alluvium that is backed by a low bar of gravel. We assume that this bar is the upper terrace Rice spoke of, and that the alluvium represents the lower terrace. Artifacts include projectile points of the Rabbit Island stemmed type, Cold Springs side-notched type and small, contracting stemmed types, a dentalium shell bead, flakes of various materials, cobble cores, hammerstones, mussel shell, bone, and FCR. Mussel shell is found in only the downriver 
two-thirds of the site, along with the Rabbit Island stemmed point. The small stemmed point, which is at least 1000 years younger, was in an area largely free of shell, while the side-notched point occurred at the northernmost end, where artifact concentrations had dropped off. This indicates that the cultural stratification of the site may be horizontal.

No recent disturbance of the site is evident, and vegetation cover is good. Fresh vehicle tracks to the north end of the site indicate that workers occasionally visit the site, but the presence of three projectile points and a shell bead on the surface indicates that surface collection activity, if any, is infrequent. Closer inspection of the gravel bar for the reported cairns is needed. If the cairns are found, that portion of the site will be added to 45BN124, the cemetery.

45BN126. Rice (1968) described this site as scattered concentrations of FCR, cobble tools and notched net sinkers, some $60 \mathrm{~m}$ by $10 \mathrm{~m}$ in extent. HCRL staff found this description to be essentially unchanged. Small concentrations of burned and fractured rock occur at the base of a 3-m-high bank of early Holocene alluvium that is devoid of cultural material. The artifacts have apparently eroded out of a lower, late Holocene terrace that still exists just downstream. One of the concentrations, which also includes flakes and cobble cores, occurs adjacent to the upriver end of this lower terrace.

Vegetation cover is dense at this site, and erosion is insignificant. There is no evidence of recent disturbance, and surface collection, if practiced, would be impeded by the vegetation.

45BN132. Records describe this site as scattered concentrations of FCR and a few cobble cores on the northeast corner of the large high-water island south of 100-F. Dimensions are given as 30 by $100 \mathrm{~m}$.

HCRL staff found that the area designated as a site is a deflated gravel terrace that shows evidence of gold mining activity, which can be seen on the photographs in Rice (1968). Only one artifact concentration was observed, near the downriver end of the terrace, where a low rise $20 \mathrm{~m}$ long and $4 \mathrm{~m}$ wide consisted of over $25 \%$ broken stones and a few possible cobble cores. It is entirely deflated, and any small lithics or bone that might have been present appear to have been washed away. We recommend removing this site from the Hanford North Archaeological District and its elimination from the list of sites that require monitoring.

45BN133. This is listed as a housepit site located at the southern tip of a high-water island south of 100-F. Four or five housepits are reported, plus several concentrations of FCR weathering from the cut bank. 
The 1989 site visit found a site with a dense cover of vegetation, including giant wildrye, which is found on large housepit sites at Wahluke and Locke Island. Despite the dense cover, one FCR concentration was seen $30 \mathrm{~cm}$ below the surface in a cut bank, and two possible housepit depressions were observed. From this we conclude that the site description is accurate.

There is no evidence or erosion except for one small game trail. No holes were seen and surface collection at the site would be impossible.

45BN134. This site, reportedly consisting of small scatters of FCR and hearth areas in the cut bank, could not be found despite careful inspection of the area in which it was mapped. Vegetation cover on the eroded gravel surface below the cut bank diminished visibility there, but the exposed cut bank was readily inspected. We recommend removing this site from the Hanford North Archaeological District.

\section{B.2.3 Locke Island Archaeological District}

45BN140. This site is described above under 45BN139, in which it should be included.

45GR302a. This is the largest and most intact of the housepit villages on the Hanford Site. Rice (1968) describes it as containing at least 60 house pits and innumerable storage pits covering an area $760 \mathrm{~m}$ long and $150 \mathrm{~m}$ wide. Artifacts of all kinds, from hopper mortar bases to large and small corner-notched projectile points were found.

The HCRL staff found Rice's description to be essentially accurate. A crew of students from Central Washington University began mapping of the site, and recorded over 100 depressions larger than $4 \mathrm{~m}$ in diameter in the southern one-half of the area. Hearths, bone, shell, and flakes can be seen in cut banks and walls of Rice's test pits to a depth of $2.4 \mathrm{~m}$; housepits exhibit multiple reoccupation episodes. Artifacts are not, however, common on the uneroded site surface, which is covered by historic flood sediments, giant wildrye, and cheatgrass.

Although it is in large measure intact, 45GR302a has sustained various kinds of disturbance, which are largely confined to the beach and bank edge in the southern one-fifth of the site area. Small pits have been scratched in the beach as recently as 1988 , and their contents have been screened. Older disturbances consist of two excavations into the west bank that are over $2 \mathrm{~m}$ wide and up to $20 \mathrm{~m}$ long. They do not appear to be over $50 \mathrm{~cm}$ deep, however. More serious disturbance includes small shovel pits (ca 40-cm diameter, up to $50 \mathrm{~cm}$ deep) that occur in the centers of approximately $10 \%$ of the housepits, all at the southern end of the site. Grass is growing on the backdirt, and dead vegetation fills the holes. In addition, two trenches, $1.5 \mathrm{~m}$ wide, $8 \mathrm{~m}$ long, and up to $2 \mathrm{~m}$ deep lie open in two of the deepest housepits. Pit walls have begun to collapse in some 
places, and the pits expose house floor deposits to possible looting (which, surprisingly, has not occurred). These pits were excavated in the early 1970 s by a Mid-Columbia Archaeological Society crew under Rice's direction.

\section{B.2.4 Ryegrass Archaeological District}

45BN149 (and enclosed 45BN179,180). In his Ben Franklin Dam survey report, Rice (1968) described this site as a group of 8 to 10 housepits on the first terrace above the Columbia River. The map of the site shows the site covering the entire low terrace, approximately $330 \mathrm{~m}$ long and $60 \mathrm{~m}$ wide. Later, during Section 106 review for the Washington Public Power Supply System (Rice 1980, 1983), Rice located two other sites, 45BN179 (the Hanford Generating Plant Site) and $45 \mathrm{BN} 180$, within the boundaries of 45BN149. Site 45BN179 is at the extreme north end the site; 45BN180, which contained two housepits, was on a slightly higher terrace behind it. Test excavations within $4 \mathrm{~m}$ of the northwestern edge of 45BN179 revealed archaeological deposits dating from historic Wanapum back to $7000 \mathrm{yr}$ B.P. Housepits were visible in pit walls, although not on the now gravel-covered surface. Two housepits were identified on the surface at 45BN180, but test excavation into one of them revealed few artifacts.

During the 1989 visit, HCRL staff found that 45BN149, which is intended here to be inclusive of 45BN179 and 45BN180, consisted of two terrace levels of apparent Holocene age. The lower terrace, approximately $1.5 \mathrm{~m}$ above the river's high water line, contains Rice's test pit, which contained fine alluvium postdating 4000 B.P. overlying a lag deposit dating to $7000 \mathrm{yr}$ B.P. The upper terrace stands approximately $1 \mathrm{~m}$ above the lower, and was the location of housepits identified as 45BN180. Shell midden has been exposed in the upper terrace by recent disturbance and may be an intact portion of the early component found lagged out under the lower terrace. The surface of both terraces has been covered by a layer of sand and gravel up to $30 \mathrm{~cm}$ thick, and housepits are no longer visible. Combined, the terraces are not over $40 \mathrm{~m}$ wide.

This site has received severe impacts of several kinds since its placement on the National Register. First, the gravel veneer was laid down sometime before Rice's excavations in the late 1970s. Second, a Bonneville Power Administration transmission tower now stands where housepits once were visible in the $45 \mathrm{BN} 180$ area, and the housepits were obliterated by surface leveling during construction. Third, a 15 -m-wide fire break has been bulldozed the length of the site (45BN149), scoring some 20 to $30 \mathrm{~cm}$ into the surface of the upper terrace and damaging an undetermined amount of the early archaeological component there. As much as half the upper terrace has been damaged by this fire break. Lack of weed development on the exposed ground indicates the damage occurred in spring or summer 1989. 
Gravel deposition probably preceded the NHPA, and Rice conducted Section 106 procedures for 45BN180. However, the cutting of the fire break was not preceded by Section 106 review.

\section{B.2.5 Hanford Island Archaeological Site}

45BN121. Rice (1968) describes this as a housepit site $300 \mathrm{~m}$ long and $100 \mathrm{~m}$ wide on the southern tip of Hanford Island. It is said to consist of four to five filled housepits, scattered FCR concentrations, net sinkers, and cobble tools.

The HCRL staff found that the island is a 500-m long ellipse of sand that caps a cobble-toboulder bar. The sediments are alluvial sand up to $3.5 \mathrm{~m}$ thick, which is overlain by as much as $1 \mathrm{~m}$ of eolian sand at the downriver end. Two sites were found, neither of which contains or is likely to have contained, housepits. One is located within $50 \mathrm{~m}$ of the island's downriver end and consists of multiple strata of FCR, cobble cores, and flakes in the bedded alluvium. Artifacts in lag deposits on the beach consist of nearly $50 \%$ cobble cores and basalt spall knives and $50 \%$ FCR. Any net sinkers that might have been there have been picked up. The second site extends approximately $100 \mathrm{~m}$ along a deflated gravel terrace on the northeastern edge of the island and can be seen within $30 \mathrm{~cm}$ of the surface of alluvium. Artifact composition is similar to that seen at the southern tip of the island.

A 1-m-deep, 3- $\mathrm{m}^{2}$ pit has been excavated into eolian sand at the southern tip of Hanford Island. The excavation does not appear to have disturbed cultural deposits, but it has damaged footings of the warning sign that marks the southern boundary of the restricted area. No other disturbance was evident, although the lack of net sinkers indicates that beaches have been surface collected.

\section{B.2.6 Paris Archaeological Site}

45GR317. This site is described as a group of buried housepits and graves weathering out of an alluvial terrace and extensive lag deposits extending for $1000 \mathrm{~m}$ along the north bank of the Columbia River. Artifacts described are characteristic of the Cayuse Phase ( $<2000 \mathrm{yr}$ B.P.). The beach area has been extensively dug over by relic collectors, whereas the intact portions of the site have been left alone. Rice's group dug test pits in the site, but no map of pit locations has been published.

HCRL staff monitored this site in October 1988 and found that, except for being less than half the size reported, its condition is unchanged. Housepits can still be seen in the alluvial terrace, which shows little sign of disturbance, and the beach area has been dug over. We did not see 
evidence of graves, however, nor did any pits from which graves could have been removed exist in the river bank. We also found that the lag deposit consisted largely of artifacts attributable to the Cascade Phase, including Cascade and Cold Springs side-notched projectile points.

Disturbance is limited to the activities of relic collectors, who clearly continue to visit this site. A three-pronged tool has been used to scratch at house floor deposits in the cut bank, and extensive pits have been dug within the last year into beach deposits. Active relic collection is more severe here than at any other site except perhaps 45GR258, where intact sediments are being affected.

\section{B.3 SITES NOT LISTED ON THE NATIONAL REGISTER OF HISTORIC PLACES}

45BN148. This site is described as a group of four to five housepits on the first terrace above the river near the 100-D Area. Inspection in late 1988 found that the site, which extends $200 \mathrm{~m}$ along the terrace and has a depth of approximately $40 \mathrm{~cm}$, has been $80 \%$ destroyed by soil burrowing activities. No evidence of housepits remains, and there is no indication of disturbance within approximately a decade. Further evaluation is not recommended.

45BN152. Rice (1968) states that this as a 150-m-long, 60-m-wide campsite consisting of scattered FCR concentrations, cobble cores, and notched sinkers on the shoreline above Coyote Rapids. The area is now heavily vegetated, and the river cobbles are slime covered. One hopper mortar base and four cobble cores were observed in the fall of 1988 . There is no recent disturbance; the site appears to lie on the beach, since no alluvial terrace exists at this location. No evidence of disturbance could be found, although the lack of notched sinkers demonstrates that surface collection has occurred. Further evaluation is not recommended.

45BN153. Rice (1968) describes this as a campsite containing four to five housepits extending $180 \mathrm{~m}$ by $45 \mathrm{~m}$ along an alluvial terrace of the Columbia River. A gravel pit is said to have disturbed inland portions of the site. HCRL staff found no evidence of housepits and, despite good bank and surface exposure, saw hittle evidence of human activity at this location. Further evaluation is not recommended.

$\underline{45 \mathrm{BN} 154}, \underline{45 \mathrm{BN} 155}$, and $45 \mathrm{BN} 156$. These three sites are located on a low-lying gravel terrace downstream of Vernita Bridge. All are described as small concentrations of FCR without associated artifacts. These locations were visited and, despite a thorough search, could not be found. These sites should be removed from state records; no future monitoring is warranted. 
45BN157A. When recorded in the late 1960s, this extensive site (Vernita Site) contained housepits, and a wide array of artifacts were visible on the surface (Rice 1968). The housepits, although still distinguishable, had been seriously disturbed by relic collectors. Test excavations were conducted there by the MCAS in 1974 and 1975 to determine if any undisturbed deposits remained and to obtain data to support a possible nomination to the National Register. They found that, although the Cayuse Phase component of the site had been virtually obliterated, there were relatively intact Frenchman Springs and Cascade Phase components in deeper strata. Portions of the site were also leveled during the Hanford Site cleanup at about the same time, intended partially to eliminate the danger posed by the many collector-dug pits.

The Vernita Site of 1989 is changed considerably. The fresh collector excavations are largely absent, and old ones have either become overgrown or are wind eroded to the point of being indistinguishable from natural blowouts. No evidence of housepits remains and, although FCR fragments, shell, and bone still litter the ground, few shaped artifacts can be seen.

Threats to the integrity of this site continue, although at a slower pace than before 1975. Three recently dug pits occur at the site's east end, within $200 \mathrm{~m}$ of the Vemita rest stop on State Highway 240. These are 1 to $2 \mathrm{~m}$ in diameter and under $1 \mathrm{~m}$ deep, and the backdirt has been screened. Two smaller scratchings are present near the middle of the site at river's edge. Neither is over $30 \mathrm{~cm}$ across, and neither shows evidence of having been screened. A grove of trees at the site's extreme west end is often used for camping, and boaters launch their craft from at least one area of the site. Frequent visitation of the site by campers and boaters may account for the absence of shaped artifacts on the surface.

Data obtained from the site in the 1970s needs to be analyzed so that nomination to the National Register can proceed. Additional test excavation near the east end of the site would also be useful for nomination

45GR315. This is listed as a 600 -m-long, 90-m-wide site containing filled housepits, scattered concentrations of FCR, cobble tools, notched sinkers, a hopper mortar base, large stemmed projectile points, and a small side-notched projectile point (Rice 1968). Despite a thorough search of the area shown on Rice's maps, no cultural material of any kind was found in the vicinity. A much smaller campsite containing possible housepits was located $300 \mathrm{~m}$ upstream from the mapped site. That site, which appears to date within the last 2500 yr B.P., has been dug into recently by relic collectors, although pits are all situated along the former high water mark. This new site warrants further investigation and evaluation. 
45GR316. This site is described as a 90-m-long, 60-m-wide campsite consisting of scattered FCR and shell concentrations apparently dating to the Frenchman Springs and Late Cayuse Phases (Rice 1968). It had been partially destroyed by pumphouse and access road construction, and had a homestead at its western end. The site observed in 1989 was quite different. Except for the vicinity of the former pumphouse and homestead, this is a dense concentration of artifacts coinciding with a mid-level Holocene terrace that extends for over $550 \mathrm{~m}$. Small shells of Margaritifera falcata and concentrations (actually more like mounds of large FCR) are abundant. Chipped stone is relatively uncommon, but four projectile points attributable to the Frenchman Springs Phase were found. Rodent mounds bear evidence that buried artifact deposits exist to an undetermined depth.

There is no evidence of relic collector activity, but the western one-third of the site has been disturbed by excavation of a gravel pit and leveling of the homestead and pumphouse areas, probably during the Hanford Site cleanup of the mid-1970s. Test excavations should be conducted at this site to obtain data for a National Register evaluation.

45GR318. HCRL staff found that this site still closely fits the earlier description. It is a dune area that exhibits extensive wind erosion and has been intensively worked by relic hunters. Artifacts, including FCR, hopper mortar bases, cryptocrystalline flakes, and cobble cores are abundant. None of the projectile points observed previously were still present. There is no evidence of recent digging by collectors, although the absence of projectile points attests to surface collection. Given its disturbed state, the site does not warrant further evaluation efforts.

45GR320. Rice (1968) described this as a 240-m-long, 45-m-wide scatter of FCR and shell on the north bank of the Columbia River above Vernita Bridge. HCRL staff were able to find only one small, thin scatter of shell on a $15-$ by $50-\mathrm{m}$ terrace remnant. Two cobble cores were seen, but no FCR. There is no evidence of disturbance. Further evaluation of this site is not warranted at this time.

\section{REFERENCES}

Krieger, H. W. 1928. "A Prehistoric Pithouse Village Site at Wahluke, Grant County, Washington." In Proceedings of the United States National Museum 73:1-29, United States Government Printing Office, Washington, D.C.

Rice, D. G. 1968. Archaeological Reconnaissance of the Hanford Atomic Works. Washington State University Laboratory of Anthropology, Pullman, Washington. 
Rice, D. G. 1980. Overview of Cultural Resources on the Hanford Reservation in South Central Washington State. Department of Energy, Richland Operations, Richland, Washington.

Rice, D. G. 1983. Archaeological Investigations at Washington Public Power Supply System Nuclear Plants on the Hanford Reservation, Washington. Washington Public Power Supply System, Richland, Washington. 

APPENDIX C

RANDOMLY SELECTED SURVEY PLOTS

INVESTIGATED IN FY 1989 


\section{APPENDIX C}

\section{RANDOMLY SELECTED SURVEY PLOTS INVESTIGATED IN FY 1989}

During the 1989 fiscal year, 16 randomly selected plots of $1 / 4$ by $1 / 4$ section size were surveyed for cultural resources as part of the Section 110 inventory of the Hanford Site. Table C.1 summarizes those plots and the cultural resources found in them. HT numbers designate archaeological sites given temporary Hanford Site numbers; $\mathrm{HI}$ designates isolated artifacts. 


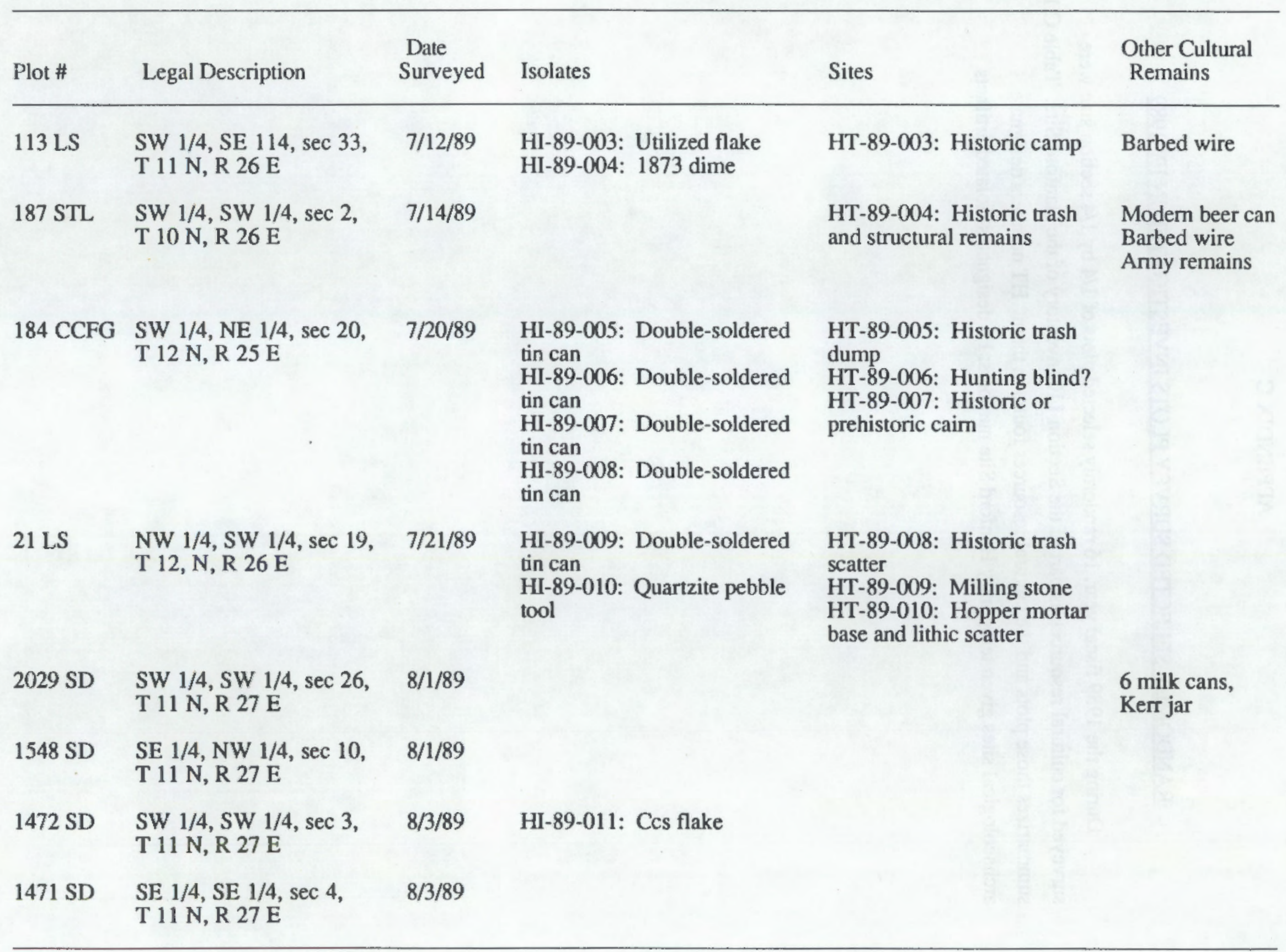




\begin{tabular}{|c|c|c|c|c|c|}
\hline Plot \# & Legal Description & $\begin{array}{l}\text { Date } \\
\text { Surveyed }\end{array}$ & Isolates & Sites & $\begin{array}{l}\text { Other Cultural } \\
\text { Remains }\end{array}$ \\
\hline 797 SD & $\begin{array}{l}\text { NW } 1 / 4, \text { SW } 1 / 4, \sec 19, \\
\text { T } 12 \text { N, R } 26 \text { E }\end{array}$ & $8 / 9 / 89$ & & & \\
\hline 1718 SD & $\begin{array}{l}\text { SE } 1 / 4, \mathrm{NE} 1 / 4, \sec 15 \text {, } \\
\text { T } 11 \mathrm{~N}, \mathrm{R} 27 \mathrm{E}\end{array}$ & $8 / 10 / 89$ & & & \\
\hline $1181 \mathrm{SD}$ & $\begin{array}{l}\text { SW } 1 / 4, \text { NW } 1 / 4, \sec 36 \text {, } \\
\text { T } 12 \mathrm{~N}, \mathrm{R} 27 \mathrm{E}\end{array}$ & $8 / 10 / 89$ & & & \\
\hline $141 \mathrm{SL}$ & $\begin{array}{l}\text { NE } 1 / 4, \text { SW } 1 / 4, \sec 17, \\
\text { T } 12 \text { N, R } 25 \mathrm{E}\end{array}$ & $8 / 15 / 89$ & & HT-89-011: Lithic scatter & . \\
\hline $46 \mathrm{AF}$ & $\begin{array}{l}\text { NE } 1 / 4, \text { NW } 1 / 4, \sec 5 \text {, } \\
\text { T } 11 \text { N, R } 25 \text { E }\end{array}$ & $8 / 15 / 89$ & $\begin{array}{l}\text { HI-89-012: Triple-soldered } \\
\text { can }\end{array}$ & $\begin{array}{l}\text { HT-89-008 continues - } \\
\text { see } 21 \mathrm{LS}\end{array}$ & $\begin{array}{l}\text { Irrigation canal } \\
\text { Old road }\end{array}$ \\
\hline $759 \mathrm{SL}$ & $\begin{array}{l}\text { SW } 1 / 4, N E 1 / 4, \sec 5 \text {, } \\
\text { T } 10 \mathrm{~N}, \mathrm{R} 27 \mathrm{E}\end{array}$ & $8 / 17 / 89$ & & $\begin{array}{l}\text { HT-89-012: Lithic scatter } \\
\text { HT-89-013: Caim and } \\
\text { bottle frag }\end{array}$ & \\
\hline $743 \mathrm{SL}$ & $\begin{array}{l}\text { NE } 1 / 4, \text { NE } 1 / 4, \sec 5, \\
\text { T } 10 \mathrm{~N}, \mathrm{R} 27 \mathrm{E}\end{array}$ & $8 / 17 / 89$ & & & Lard can \\
\hline $103 \mathrm{ES}$ & $\begin{array}{l}\text { SW } 1 / 4, \text { SW } 1 / 4, \sec 29, \\
\text { T } 12 \text { N, R } 26 \text { E }\end{array}$ & $8 / 21 / 89$ & & $\begin{array}{l}\text { HT-89-014: Cairn and } \\
\text { bottle fragments }\end{array}$ & $\begin{array}{l}\text { Purple glass } \\
\text { frags }\end{array}$ \\
\hline
\end{tabular}

LS = Landslide STL $=$ Steep slope

$\mathrm{CCFG}=$ Cold Creek fine-grained

$\mathrm{SD}=$ Stable dune

$\mathrm{SL}=$ Slope

$\mathrm{AF}=$ Alluvial fan

ES $=$ Ephemeral stream 



\section{DISTRIBUTION}

No. of

Copies

\section{OFFSITE}

2 DOE/Office of Scientific and

Technical Information

Jacob Thomas

State Historic Preservation

Officer

Office of Archaeology \& Historic

Preservation

111 West 21st Ave., KL-11

Olympia, WA 98504-5411

Thomas King

Advisory Council on Historic

Preservation

The Old Post Office Building

1100 Pennsylvania Ave., NW \#809

Washington, D.C. 20004

Duane Hogan

U.S. Army Corps of Engineers

Box C-3755

Seattle, WA 98124-2255

Dennis Canty

National Park Service, Pacific

Northwest Region

83 King St., Suite 212

Seattle, WA 98104

John Leier

U.S. Army Corps of Engineers

Walla Walla District

Building 602, City-County Ariport

Walla Walla, WA 99362-9265

Bruce Crespin

U.S. Bureau of Land Management

Burns, OR 97720
No. of

Copies

2 Colville Confederated Tribes

Attn: Tribal Council

Adeline Fredin

P.O. Box 150

Nespelem, WA 99155

2 Nez Perce Tribe

Attn: Tribal Council

Alan Slickpoo

P.O. Box 305

Lapwai, ID 83540

2 The Confederated Tribes of the Umatilla Indian Reservation

Attn: Tribal Council Jeff Van Pelt

P.O. Box 638

Pendleton, OR 97810

2 The Wanapum Indian Tribe

Attn: Tribal Council Rex Buck, Jr.

P.O. Box 275

Beverly, WA 99321

2 The Yakima Indian Nation

Attn: Tribal Council Bill Yallup

P.O. Box 151

Toppenish, WA 98948

ONSITE

26 DOE Richland Operations Office

K. V. Clarke (15)

P. F. Dunigan

N. M. Highland

M. B. Hitt 
No. of

$\underline{\text { Copies }}$
R. D. Izatt
K. H. Jackson
E. E. Pride
J. R. Shadel
P. H. Turner
K. J. Wheeless
DOE Legal Library

5 Westinghouse Hanford Company

G. D. Carpenter

M. T. Jansky

K. W. LeLiefeld

D. L. Mills

J. F. Woods

30 Pacific Northwest Laboratory

T. L. Brown

N. A. Cadoret
No. of

Copies

J. C. Chatters (20)

C. E. Cushing

J. W. Falco

R. H. Gray

J. M. Hales

P. C. Hays

R. E. Jaquish

S. F. Liebetrau

P. E. Minthorn

W. T. Pennell

W. H. Rickard

L. E. Rogers

R. L. Skaggs

Publishing Coordination

Technical Report Files (5) 